\title{
Plutonium-238 Alpha-Decay Damage Study of the Ceramic Waste Form
}

prepared by

Engineering Technology Division

Argonne National Laboratory-West 


\section{About Argonne National Laboratory}

Argonne is managed by The University of Chicago for the U.S. Department of Energy under contract W-31-109-Eng-38. The Laboratory's main facility is outside Chicago, at 9700 South Cass Avenue, Argonne, Illinois 60439. For information about Argonne and its pioneering science and technology programs, see www.anl.gov.

\section{Availability of This Report}

This report is available, at no cost, at http://www.osti.gov/bridge. It is also available on paper to U.S. Department of Energy and its contractors, for a processing fee, from:

U.S. Department of Energy

Office of Scientific and Technical Information

P.O. Box 62

Oak Ridge, TN 37831-0062

phone (865) 576-8401

fax (865) 576-5728

reports@adonis.osti.gov

\section{Disclaimer}

This report was prepared as an account of work sponsored by an agency of the United States Government. Neither the United States Government nor any agency thereof, nor The University of Chicago, nor any of their employees or officers, makes any warranty, express or implied, or assumes any legal liability or responsibility for the accuracy, completeness, or usefulness of any information, apparatus, product, or process disclosed, or represents that its use would not infringe privately owned rights. Reference herein to any specific commercial product, process, or service by trade name, trademark, manufacturer, or otherwise, does not necessarily constitute or imply its endorsement, recommendation, or favoring by the United States Government or any agency thereof. The views and opinions of document authors expressed herein do not necessarily state or reflect those of the United States Government or any agency thereof, Argonne National Laboratory, or The University of Chicago. 


\section{Plutonium-238 Alpha-Decay Damage Study of the Ceramic Waste Form}

by

S.M. Frank, ${ }^{*}$ T.L. Barber, ${ }^{*}$ D.G.Cummings, ${ }^{*}$ T.DiSanto, ${ }^{*}$ D.W. Esh, ${ }^{* *}$ J.J.Giglio, ${ }^{*}$ K.M.Goff, ${ }^{*}$

S.G.Johnson, ${ }^{*}$ J.R. Kennedy, ${ }^{*}$ J-F Jue, ${ }^{*}$ M. Noy, ${ }^{*}$ T.P.O ${ }^{\prime}$ Holleran, ${ }^{*}$ and W. Sinkler ${ }^{* * *}$

Engineering Technology Division, Argonne National Laboratory-West

* Current Affiliation: Idaho National Laboratory, P.0.Box 1625, Idaho Falls, ID 83415

** Current Affiliation: U.S. Nuclear Regulatory Commission, Washington, DC 20555-0001

*** Current Affiliation: UOP LLC, 25 E Algonquin Road, Des Plaines, IL 60017 


\section{TABLE OF CONTENTS}

Page

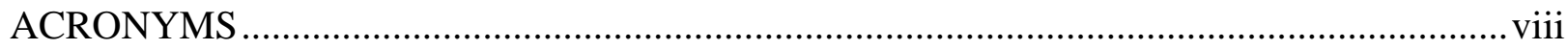

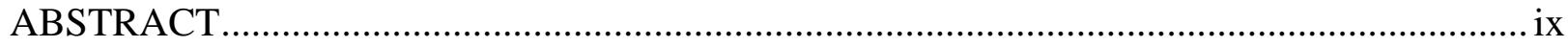

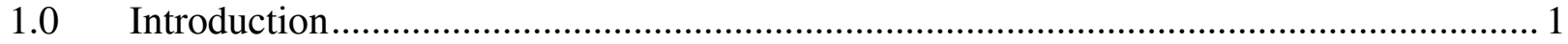

2.0 Production of the ${ }^{238} \mathrm{Pu}$-Loaded Ceramic Waste Form .................................................... 2

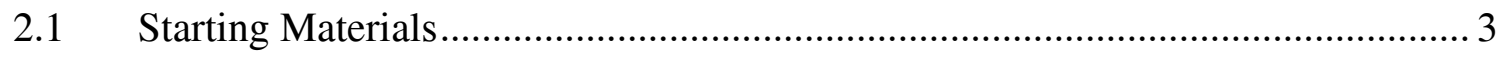

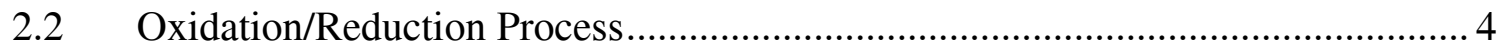

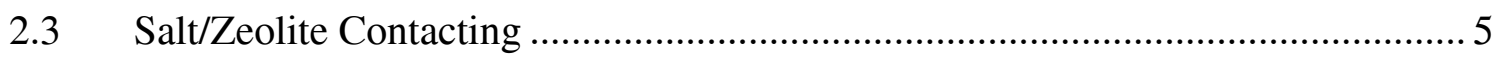

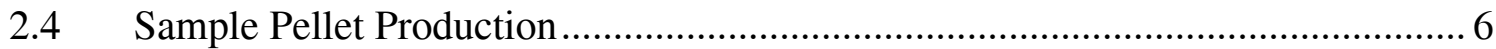

3.0 Characterization and Testing of the ${ }^{238} \mathrm{Pu}$-Loaded Ceramic Waste Form ........................ 9

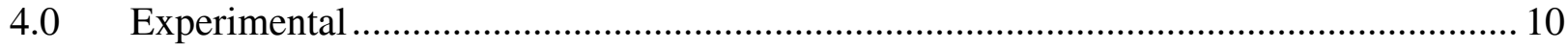

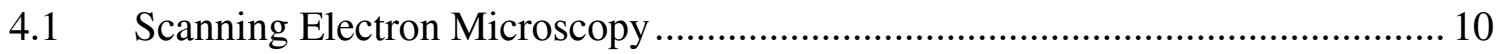

4.2 Transmission Electron Microscopy ……………........................................ 12

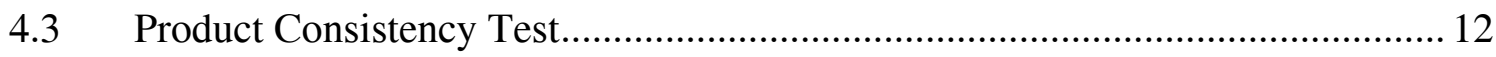

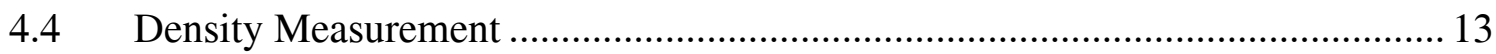

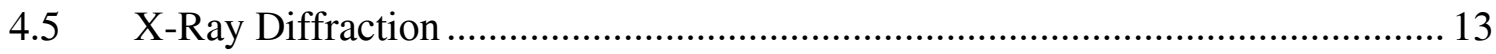

4.6 ${ }^{238} \mathrm{Pu}$ CWF Isotopic Measurement ................................................................. 14

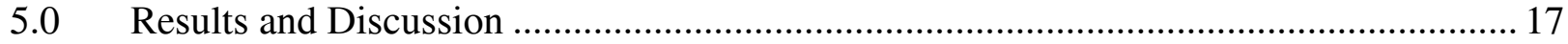

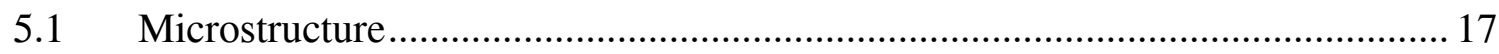

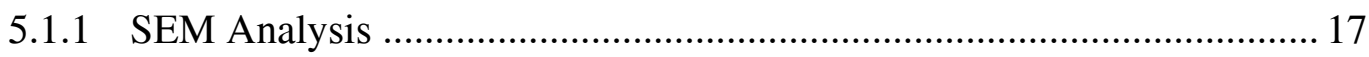

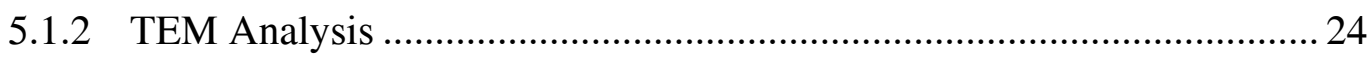

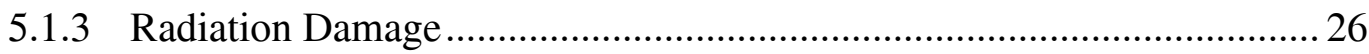

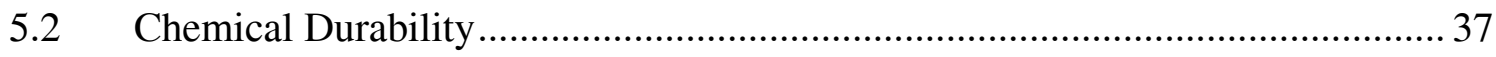

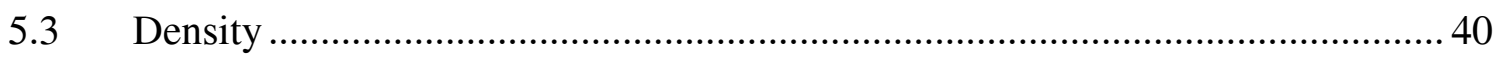

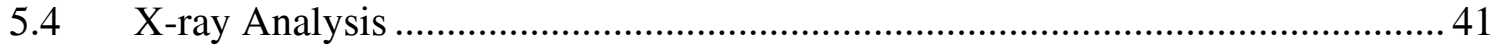

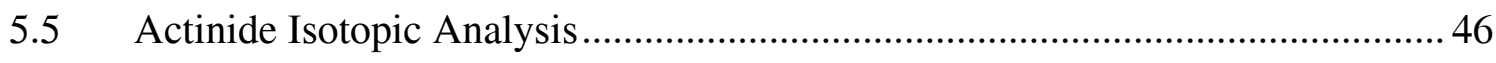

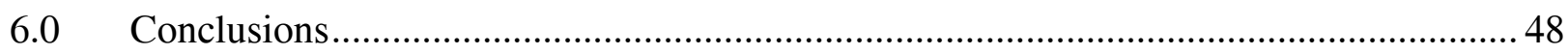

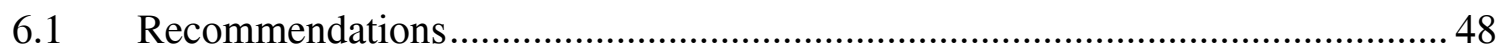

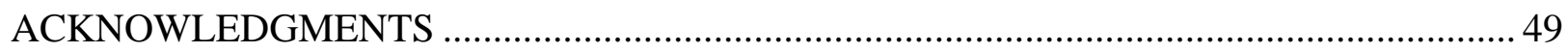

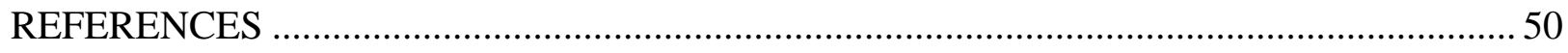

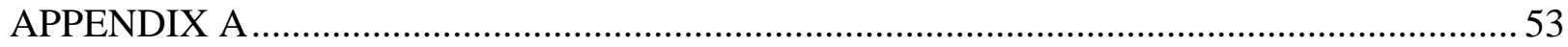




\section{LIST OF FIGURES}

Page

I1. Schematic of ${ }^{238} \mathrm{Pu}$-CWF HUP Pellet Production Process ................................................. 7

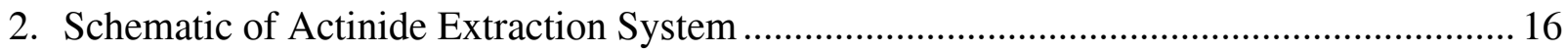

3. SEM Analysis of Selected Region of the ${ }^{238} \mathrm{Pu}$-loaded CWF Sample (a) Shortly After the HUP Pellet was Produced and (b) After Three Years or 1.1 x 1018 alpha decays/g Cumulated Dose................................................................... 18

4. Low Magnification Secondary Electron Image Showing Porosity and Overall Microstructure Higher Magnification Back Scattered Electron Image

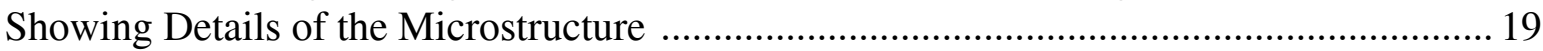

5. Back Scattered Electron Image of a Relatively Large Rare Earth Inclusion 19

6. Results from X-ray Maps of a Representative Region of HUP Pellet CL036, Back Scattered Electron Image of the Mapped Region Also Showing Locations of Point Spectra Used to Quantify Phase Compositions, Plutonium Ma X-ray WDS Map, Aluminum Ka X-ray EDS Map, Silicon Ka X-ray Map Processed by Subtracting the Al Ka Signal to Enhance Silicon Rich Regions, Iron Ka X-ray Map.

7. Back Scattered Electron Image of the $\mathrm{PuO}_{2}$ Inclusion Used to Calibrate the WDS System

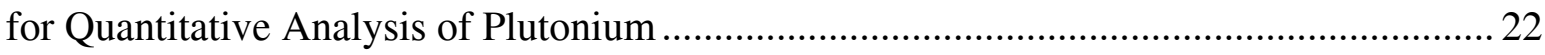

8. Energy Dispersive X-ray Spectrum from the Spot Indicated in Fig. 7 7.............................. 22

9. A Bright Field Transmission Electron Micrograph Showing the Typical Microstructure of the ${ }^{238} \mathrm{Pu}$ Doped Ceramic Waste Form. 25

10. A Bright Field Transmission Electron Micrograph Showing a Large Plutonium Bearing Particle in the Glass Phase …………………………........................................... 25

11. A Bright Field Transmission Electron Micrograph Showing a Cluster of Plutonium Bearing Particles in the Glass Phase...

12. Bright Field Transmission Electron Micrographs Showing the Microstructure of a Ceramic Waste Form Sample Without ${ }^{238} \mathrm{Pu}, \mathrm{a}{ }^{238} \mathrm{Pu}$ Doped Ceramic Waste Form Sample Aged For Four Years.

13. A Bright Field Transmission Electron Micrograph Showing Bubbles in the ${ }^{238} \mathrm{Pu}$ Doped Ceramic Waste Form Sample.

14. A Bright Field Transmission Electron Micrograph Showing Bubbles in a Ceramic Waste Form Sample Without ${ }^{238} \mathrm{Pu}$.

15. A Bright Field Transmission Electron Micrograph Showing a Large Plutonium Bearing Particle in the Glass Phase

16. A Bright Field Transmission Electron Micrograph Showing a Region Containing Sodalite Grains, Glass, and Plutonium Bearing Particles.

17. A Bright Field Transmission Electron Micrograph Showing the Same Region as Fig. 16 After Exposed to an Intense Electron Beam.

18. TEM Micrograph with Contrast Dominated by Absorption Properties ……………................ 32

19. EDS Spectrum from a Particle of Unidentified Tetragonal Phase 


\section{LIST OF FIGURES (Contd.)}

$\underline{\text { Page }}$

20. Selected Area Diffraction Pattern's From Unknown Tetragonal Phase [001],

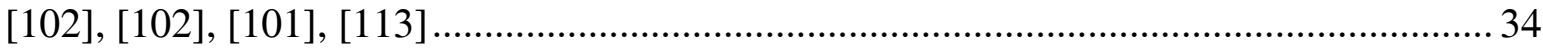

21. Bright Field Image of a Particle of the Unknown Tetragonal Phase ......................................36

22. XRD Patterns of HUP Starting Materials and Final CWF Product........................................ 42

23. Unit Cell Volume Increase of $\mathrm{PuO}_{2}$ and Sodalite Phase in ${ }^{238} \mathrm{Pu}$-loaded CWF with Cumulated Alpha-decay Dose ..................................................................................... 44

24. Swelling With Cumulated Alpha-Decay Dose for Various Mineral Systems Containing Actinides Including the $\mathrm{PuO}_{2}$ and Sodalite Phases from the ${ }^{238} \mathrm{Pu}$-loaded CWF ................ 46 


\section{LIST OF TABLES}

Page

1. Starting Materials and Characteristics Used in the Production of the ${ }^{238} \mathrm{Pu}$-Loaded CWF

2. Quantity of Each Component Used in the Production of ${ }^{238} \mathrm{Pu}$-Salt/Zeolite/Glass

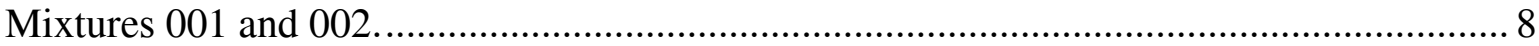

3. Weight Percent of Each Component in the Pre-Processed CWF Estimated from Process Information. 8

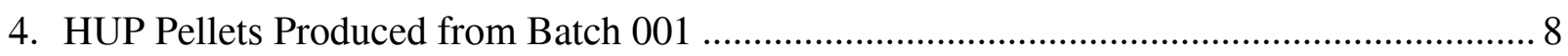

5. Testing Schedule and Corresponding Alpha Decay-Dose Rate for ${ }^{238} \mathrm{Pu}$-Loaded CWF

6. ICP-MS Operating Conditions Used For Isotopic Analysis of ${ }^{238} \mathrm{Pu} \mathrm{CWF}$ Dissolver Solution

7. Results of Batch Analysis of Sodalite, Glass, and High-Pu Aluminosilicate Phases Identified in Fig. 6 .... 23

8. Measurements of C/A Ratio of Unknown Phase, from SADP Patterns 35

9. Relative Angles, In Degrees, For The Zone Axes in Fig. 20c-e. 35

10. Normalized Elemental Release in $\mathrm{g} / \mathrm{m} 2$ for a 7 -day PCT..

11. Comparison of Normalized Elemental Release from the Reference CWF Material Containing No Pu to the ${ }^{238} \mathrm{Pu}$ CWF Material

12. Measured Density of ${ }^{238} \mathrm{Pu}$ CWF HUP Pellet CL034 with Increasing Alpha-Decay Damage

13. Phase Composition of ${ }^{238} \mathrm{Pu}$-loaded HUP Pellet CL031 in Weight Percent As Determined by XRD.

14. Actinide Concentration in Batch $1^{238} \mathrm{Pu}-\mathrm{CWF}$ Material

15. Percent Isotopic Composition of Uranium and Plutonium fromBatch 1 ${ }^{238} \mathrm{Pu}-\mathrm{CWF}$ Material

16. Comparison of As Batched Concentration to the Measured Concentration of Surrogate Fission-product Elements in Batch $1{ }^{238} \mathrm{Pu}$-CWF Material

1A. Component Masses Fractions According to Process Chemistry Analysis Based on $\mathrm{Pu}_{2} \mathrm{O}_{3}$ Formation Model.

2A. Weight Fractions of Pu Isotopes and Total Pu in Products of Process Steps to Form Ceramic Waste Form Based on $\mathrm{Pu}_{2} \mathrm{O}_{3}$ Formation Model

3A. Component Masses of Fractions According to Process Chemistry Analysis Based on $\mathrm{PuO}_{2}$ Formation Model

4A. Weight Fractions of Pu Isotopes and Total Pu in Products of Process Steps to Form Ceramic Waste Form Based on $\mathrm{PuO}_{2}$ Formation Model

5A. Component Masses of Fractions According to Process Chemistry Analysis Based on $\mathrm{Pu}_{2} \mathrm{O}_{3}$ Formation Model with Maximum Oxide Content in Magnetic Separation Phase of 2nd Oxidation 


\section{LIST OF TABLES (Contd.)}

Page

6A. Weight Fractions of Pu Isotopes and Total Pu in Products of Process Steps to Form Ceramic Waste Form Based on $\mathrm{Pu}_{2} \mathrm{O}_{3}$ Formation Model with Maximum Oxide Content in Magnetic Separation Phase of 2nd Oxidation...................................... 62 


\section{ACRONYMS}

\begin{tabular}{|c|c|}
\hline $\mathrm{AL}$ & Analytical Laboratory \\
\hline ANL & Argonne National Laboratory \\
\hline ANL-West & Argonne National Laboratory-West \\
\hline ARM & Approved Reference Material \\
\hline ASTM & American Society for Testing and Materials \\
\hline BFI & Bright Field Image \\
\hline CWF & Ceramic Waste Form \\
\hline DM & De-mineralized Water \\
\hline DOE & Department of Energy \\
\hline DTA & Differential Thermal Analyzer \\
\hline EA & Environmental Assessment \\
\hline EBR-II & Experimental Breeder Reactor-II \\
\hline EDS & Energy Dispersive Spectroscopy \\
\hline EDTA & Ethylenediamine Tetra-acetic Acid \\
\hline ER & Electrorefiner \\
\hline GSAS & General Structure Analytical System \\
\hline $\mathrm{HF}$ & Hydrofloric Acid \\
\hline HFEF & Hot Fuel Examination Facility \\
\hline HLW & High Level Waste \\
\hline HUP & Hot Uniaxial Press \\
\hline ICP-MS & Inductively Coupled Plasma-Mass Spectrometry \\
\hline LANL & Los Alamos National Laboratory \\
\hline NIST & National Institute of Standards and Technology \\
\hline PCT & Product Consistency Test \\
\hline
\end{tabular}




$\begin{array}{ll}\text { RSD } & \text { Relative Standard Deviation } \\ \text { SAD } & \text { Selected Area Diffraction } \\ \text { SADP } & \text { Selected Area Diffraction Pattern } \\ \text { SEM } & \text { Scanning Electron Microscope } \\ \text { SPF } & \text { Surrogate Fission Products } \\ \text { SRM } & \text { Standard Reference Material } \\ \text { TEM } & \text { Transmission Electron Microscope } \\ \text { WDS } & \text { Wavelength Dispersive Spectroscopy } \\ \text { XRD } & \text { X-Ray Diffraction }\end{array}$




\title{
PLUTONIUM-238 ALPHA-DECAY DAMAGE STUDY OF THE CERAMIC WASTE FORM
}

by

S. M. Frank, T. L. Barber, D. G. Cummings, T. Disanto, D. W. Esh, J. J. Giglio, K. M. Goff, S. G. Johnson, J. R. Kennedy, J-F Jue, M. Noy, T. P. O’Holleran and W. Sinkler

\begin{abstract}
An accelerated alpha-decay damage study of a glass-bonded sodalite ceramic waste form has recently been completed. The purpose of this study was to investigate the physical and chemical durability of the waste form after significant exposure to alpha decay. This accelerated alphadecay study was performed by doping the ceramic waste form with ${ }^{238} \mathrm{Pu}$ which has a much greater specific activity than ${ }^{239} \mathrm{Pu}$ that is normally present in the waste form. The alpha-decay dose at the end of the four year study was approximately $1 \times 10^{18}$ alpha-decays/gram of material. An equivalent time period for a similar dose of ${ }^{239} \mathrm{Pu}$ would require approximately 1100 years.

After four years of exposure to ${ }^{238} \mathrm{Pu}$ alpha decay, the investigation observed little change to the physical or chemical durability of the ceramic waste form (CWF). Specifically, the ${ }^{238} \mathrm{Pu}$-loaded CWF maintained it's physical integrity, namely that the density remained constant and no cracking or phase de-bonding was observed. The materials chemical durability and phase stability also did not change significantly over the duration of the study. The only significant measured change was an increase of the unit-cell lattice parameters of the plutonium oxide and sodalite phases of the material and an increase in the release of salt components and plutonium of the waste form during leaching tests, but, as mentioned, these did not lead to any overall loss of waste form durability. The principal findings from this study are:
\end{abstract}

${ }^{238} \mathrm{Pu}$-loaded CWF is similar in microstructure and phase composition to referenced waste form.

- $\quad$ Pu was observed primarily as oxide comprised of aggregates of nano crystals with aggregates ranging in size from submicron to twenty microns in diameter.

- $\quad$ Pu phases were primarily found in the intergranular glassy regions.

- $\mathrm{PuO}_{2}$ phase shows expected unit cell volume expansion due to alpha decay damage of approximately $0.7 \%$, and the sodalite phase unit cell volume has expanded slightly by $0.3 \%$ again, presumably due to alpha-decay damage.

- $\quad$ No bulk sample swelling was observed.

- $\quad$ No amorphization of sodalite or actinide bearing phases was observed after four years of alpha-decay damage. 
- $\quad$ No microcracks or phase de-bonding were observed in waste form samples aged for four years.

- $\quad$ In some areas of the ${ }^{238} \mathrm{Pu}$ doped ceramic waste form material bubbles and voids were found. Bubbles and voids with similar size and density were also found in ceramic waste form samples without actinide. These bubbles and voids are interpreted as pre-existing defects. However, some contribution to these bubbles and voids from helium gas can not be ruled out.

- $\quad$ Chemical durability of ${ }^{238} \mathrm{Pu}$ CWF has not changed significantly after four years of alpha-decay exposure except for an increase in the release of salt components and $\mathrm{Pu}$. Still, the plutonium release from CWF is very low at less than $0.005 \mathrm{~g} / \mathrm{m}^{2}$. 


\subsection{INTRODUCTION}

Argonne National Laboratory (ANL) has developed a durable ceramic waste form (CWF) to immobilize alkali, alkaline earth, rare earth and halide fission products and transuranics that accumulate during the electrometallurgical processing of spent nuclear fuel. The electrometallurgical spent fuel treatment process was developed to condition specific types of Department of Energy (DOE) spent nuclear fuel that may not be suitable for direct disposal in a geological repository. The electrometallurgical process uses an electrorefiner (ER) containing a eutectic molten salt to dissolve the fuel. Currently, ANL is processing spent Experimental Breeder Reactor-II (EBR-II) sodium-bonded metallic fuel at Argonne National Laboratory-West (ANL-West) in Idaho [1,2]. The electrometallurgical process produces, in addition to the CWF, a pure uranium product, and a metallic waste form containing the cladding material and fission products that are non-reactive in the electrorefiner (Tc, $\mathrm{Ru}, \mathrm{Rh}, \mathrm{Nb}, \mathrm{Pd}, \mathrm{Ag}, \mathrm{Zr}$ and $\mathrm{Te}$ ). The active fission products and small amounts of transuranics accumulate in the eutectic salt during fuel conditioning. Eventually, after prolonged fuel conditioning, the quantity of fission products, transuranics and bond sodium from the fuel rods in the salt becomes concentrated enough that the salt must be removed from the electrorefiner. After the salt is removed from the electrorefiner, the fission products are immobilized by mixing the salt with a zeolite material. Production of the durable CWF is accomplished by mixing salt-occluded zeolite with a glass binder and processing the mixture at high temperature to form a dense, glass encapsulate waste form [3,4]. During the heating process the zeolite is converted to the mineral phase sodalite. The resulting ceramic is durable and has a leach resistance far superior to Savannah River Environmental Assessment (EA) borosilicate glass, the benchmark for geologic disposal, and comparable to Savannah River High Level Waste glass for matrix elements [5].

For the CWF to be accepted by the Office of Civilian Radioactive Waste Management for disposal at the Yucca Mountain repository the waste form must be qualified [6]. Qualification of the waste form includes, in addition to characterization and performance data, determining the durability of the waste form after prolonged exposure to radioactive decay. Because the CWF produced from fuel conditioning operations contains roughly $0.2 \mathrm{wt} \%{ }^{239} \mathrm{Pu}$ it is important to investigate the potential effects of alpha-decay damage on the durability of the CWF. To accomplish this, a four year testing program has recently been completed using a CWF containing ${ }^{238} \mathrm{Pu}$ as opposed to ${ }^{239} \mathrm{Pu}$. The use of ${ }^{238} \mathrm{Pu}$, with its high specific activity of $6.3 \times 10^{11}$ decays/sec gram and short half-life of 88 years, allows significant alpha-decay dose accumulation by the waste form in a reasonably short period of time, thus the term accelerated alpha-decay damage study. The cumulated alpha-decay dose to the CWF after four years of exposure is approximately $1 \times 10^{18}$ alpha-decays/gram of material. To acquire an equivalent alpha-decay dose from ${ }^{239} \mathrm{Pu}$ would require approximately 1100 years. The data presented in this report concludes the four year study.

High level nuclear waste (HLW) that contains sufficient quantities of actinides undergoes various degrees of alpha radiation damage to the matrix material. This damage results from dissipation of energy from both the alpha particle and the recoil nucleus that emitted the alpha particle. The alpha particle, with an approximate energy of $5 \mathrm{MeV}$ and a typical range of $20 \mathrm{~mm}$, imparts its energy to the surrounding matrix by both electronic excitation and direct elastic collision. The 
recoiled nucleus, with energies of approximately $85 \mathrm{keV}$ and ranges of only tens of nanometers, disrupts the greatest number of neighboring atoms primarily by elastic collisions. For the alpha decay of ${ }^{239} \mathrm{Pu}$ in a crystalline matrix, the ejected alpha particle may dislocate hundreds of matrix atoms by the end of its track. The recoiled ${ }^{235} \mathrm{U}$ nucleus may displace over 1000 local atoms, depending on the atomic density and displacement energy of the material. Over the expected lifetime of a geologic repository, HLW forms containing large amounts of actinides would accumulate significant structural damage that may adversely influence the materials performance. To investigate the alpha radiation affects on potential waste form materials, accelerated alpha damage studies are conducted by incorporating a high activity radionuclide such as ${ }^{238} \mathrm{Pu}$ (274 times the activity of ${ }^{239} \mathrm{Pu}$ ) or ${ }^{244} \mathrm{Cm}$ into the material of interest $[7,8]$. Another method is to irradiate the material with heavy ions or He ions [9]. One may also study geological specimens that contain actinides [10]. Alpha-decay studies of crystalline materials or glass materials containing actinide host crystalline phases reveal that the crystalline material may become amorphous due to accumulation of dislocated matrix atoms [11,12]. Amorphization of crystalline phases leads to volume increases that may in turn lead to microcracking. Swelling and cracking of the material usually have detrimental effects on the performance of the waste form [13]. After prolonged exposure, He or other gas bubbles may develop. For a through review on the effects of alpha-decay damage, see Ref.14.

\subsection{PRODUCTION OF THE ${ }^{238}$ Pu-LOADED CERAMIC WASTE FORM}

The following discussion states quantities of materials used to make the ${ }^{238} \mathrm{Pu}$ CWF based on the best known process information at the time of production. It should be noted, however, that actual chemical and isotopic measurement of the plutonium metal starting material or the final ${ }^{238} \mathrm{Pu}$ CWF were not performed during the production phase of this project. This was due to radiological constraints of handling ${ }^{238} \mathrm{Pu}$ and because methods of analysis were not available at the time. Since that time, facilities at ANL-West have become experienced in handling ${ }^{238} \mathrm{Pu}$ and methods of separation and analysis have been developed to allow the safe-handling and analysis of the ${ }^{238} \mathrm{Pu}$ CWF. Based on this experience, the chemical and isotopic analysis of the ${ }^{238} \mathrm{Pu}$ CWF has just recently been completed. These analyses indicate a different concentration of total plutonium and of plutonium-238 in the waste form than from the process information. The analytical measurement results will be presented later in this report, but, to repeat, the quantities reported in this section were based on the original process information.

Production of the ${ }^{238}$ Pu-loaded ceramic waste form used in the accelerated alpha damage study was performed in a manner similar to actual processes involved in the electrorefiner during the treatment of spent fuel and production of the CWF. Production of samples used in this study involved four main steps:

1. Oxidation of metallic plutonium with ferrous chloride in $\mathrm{LiCl}-\mathrm{KCl}$ eutectic salt,

2. Occluding the Pu containing salt into zeolite,

3. Mixing the salt-occluded zeolite with glass binder, and 
4. Pressing the material into ceramic pellets using a hot uniaxial press (HUP). The following sections describe these steps in greater detail.

\subsection{Starting Materials}

The zeolite, salt and glass starting materials used to produce the waste form were characterized before processing and verified to be acceptable. The plutonium metal supplied by Los Alamos National Laboratory (LANL) was not measured, but assumed to be acceptable based on the LANL assay that identified a Pu metal composition of $88 \mathrm{wt} \%$ of ${ }^{238} \mathrm{Pu}$ with a balance of ${ }^{239} \mathrm{Pu}$. There was an increased weight discrepancy of approximately 8\% between the LANL reported weight and the ANL verified weight and this was assumed to be due to formation of an oxide layer on the metal (see Appendix A). A total of two batches (batch 001 and 002 respectively) of $\mathrm{Pu}$ containing, salt-occluded zeolite and glass were produced and from this a total of $52 \mathrm{CWF}$ pellets were made. All of the CWF pellet samples used in this study came from batch 001. At a latter time during the clean-up from the ${ }^{238} \mathrm{Pu}$ CWF campaign, a number of "recovery" pellets were produced also. Table 1 provides a list of starting materials and their characteristics used in the production of the two ${ }^{238} \mathrm{Pu}$ containing zeolite/glass batches.

Table 1. Starting Materials and Characteristics Used in the Production of the ${ }^{238} \mathrm{Pu}$-Loaded CWF

\begin{tabular}{|c|c|c|c|}
\hline Material & Description & $\begin{array}{l}\text { Processing } \\
\text { Conditions }\end{array}$ & Properties \\
\hline Eutectic salt & $\begin{array}{l}\text { High purity ER salt, } \\
\text { APL }\end{array}$ & NA & 70-30 mole\% LiCl-KCl \\
\hline Glass binder & P-4N-57-P, Bayer & NA & $\begin{array}{l}\mathrm{SiO}_{2}=66.5, \mathrm{~B}_{2} \mathrm{O}_{3}=19.1, \mathrm{Al}_{2} \mathrm{O}_{3}=6.8, \\
\mathrm{Na}_{2} \mathrm{O}=7.1, \mathrm{~K}_{2} \mathrm{O}=0.5 \text { in weight percent }\end{array}$ \\
\hline Dried zeolite & $\begin{array}{l}\text { 4A50, KD009, } \\
\text { UOP }\end{array}$ & $550 \times \mathrm{C}, 12.4 \mathrm{hr}$ & Moisture Content $0.175 \mathrm{wt} \%$ on $5 / 22 / 98$ \\
\hline Pu-SFP salt & $\begin{array}{l}\text { SFP salt } \\
\text { composition similar } \\
\text { to ER salt after } \\
\text { processing } 100 \\
\text { driver fuel } \\
\text { assemblies }\end{array}$ & $550 \times C, 5 \mathrm{hr}, 30 \mathrm{~g}$ & $\begin{array}{l}\text { LiCl-KCl }=58.3, \mathrm{NaCl}=14.9, \mathrm{KBr}= \\
0.04, \mathrm{RbCl}=0.58, \mathrm{SrCl}_{2}=1.77, \mathrm{YCl}_{3}= \\
\text { 1.23, } \mathrm{KI}=0.27, \mathrm{CsCl}=4.40, \mathrm{BaCl}_{2}= \\
\text { 2.10, } \mathrm{LaCl}_{3}=2.14, \mathrm{CeCl}_{3}=4.09, \mathrm{PrCl}_{3}= \\
\text { 2.02, } \mathrm{NdCl}_{3}=6.83, \mathrm{SmCl}_{3}=1.20, \mathrm{EuCl}_{3} \\
=0.08 \text { in weight percent }\end{array}$ \\
\hline Pu-238 No. 1 & ID 785 & NA & $\begin{array}{l}\text { Mass in }(\text { LANL })=1.814 \mathrm{~g} \\
\text { Mass out }(C L)=1.959 \mathrm{~g}\end{array}$ \\
\hline Pu-238 No. 2 & ID 791 & NA & $\begin{array}{l}\text { Mass in }(\mathrm{LANL})=1.90 \mathrm{~g} \\
\text { Mass out }(\mathrm{CL})=2.066 \mathrm{~g}\end{array}$ \\
\hline $\mathrm{FeCl}_{2}$ & Aldrich & NA & High purity (AL assay 100.3\%) \\
\hline
\end{tabular}

$\mathrm{ER}=$ electrorefiner

$\mathrm{SFP}=$ surrogate fission products 


\subsection{Oxidation/Reduction Process}

To mimic conditions in the electrorefiner, plutonium metal, with an isotopic composition of approximately $88 \mathrm{wt} \%{ }^{238} \mathrm{Pu}$ and the majority of the balance being ${ }^{239} \mathrm{Pu}$, was oxidized to the chloride form using $\mathrm{FeCl}_{2}$ as the oxidizing agent. Before using the ${ }^{238} \mathrm{Pu}$ material, experiments were performed using ${ }^{239} \mathrm{Pu}$ metal in order to develop an understanding of the process. The initial process involved a one-step oxidation/reduction reaction in which stoichiometric amounts of $\mathrm{Pu}$ metal and $\mathrm{FeCl}_{2}$ were mixed with $\mathrm{LiCl}-\mathrm{KCl}$ eutectic in an alumina crucible. The crucible was then heated to $500^{\circ} \mathrm{C}$ and mixed with a steel stirrer resulting in the following reaction:

$$
2 \Pi v(m)+3 \mathrm{FeCl}_{2} \rightarrow 2 \mathrm{PuCl}_{3}+3 \mathrm{Fe}(\mathrm{m})
$$

After the oxidation/reduction reaction, the resulting ingot was removed from the crucible and ground to a powder using a micromill. The metallic iron was then magnetically separated from the salt. The two reactant products were then analyzed by dissolving the magnetically separated $\mathrm{Fe}(\mathrm{m})$ in acid followed by elemental analysis, and by first mixing the remaining salt with water and measuring the chloride concentration then dissolving the insoluble material and performing elemental analysis.

From these initial experiments using ${ }^{239} \mathrm{Pu}$ metal, it was determined that material loss occurred due to salt adhesion to the crucible, stirrer and to the magnetically separated $\mathrm{Fe}(\mathrm{m})$. In order to reduce salt loss to $\mathrm{Fe}(\mathrm{m})$ adhesion, the ingot was ground for less time (just a few seconds) producing larger $\mathrm{Fe}(\mathrm{m})$ particles with lower surface area for salt adhesion then with larger surface areas associated with finely ground powder. It was also observed that not all of the $\mathrm{Pu}$ was reacting and the possibility existed that $\mathrm{FeCl}_{2}$ might still be present in the salt fraction. This was deemed undesirable due to the reactive nature of $\mathrm{FeCl}_{2}$ and possible consequences to the final waste form. Therefore, a second step was added after magnetic separation of the iron and salt, and this involved addition of a large, solid piece of ${ }^{239} \mathrm{Pu}$ metal to the salt and reacting at elevated temperatures. This assured complete reaction of the $\mathrm{FeCl}_{2}$. The solid piece of $\mathrm{Pu}(\mathrm{m})$ was then removed from the remaining salt.

After initial oxidation/reduction processing experience using ${ }^{239} \mathrm{Pu}(\mathrm{m})$, the project proceeded to processing the ${ }^{238} \mathrm{Pu}(\mathrm{m})$ using the two-step method. The ${ }^{238} \mathrm{Pu}(\mathrm{m})$ required for sample production was processed to the chloride in two separate batches identified as experiment 008 and 009 with a ${ }^{238} \mathrm{Pu}$ salt target composition of $10 \mathrm{~mol} \%$. These experiments involved the initial oxidation/reduction steps using stoichiometric amounts of $\mathrm{FeCl}_{2}$ and ${ }^{238} \mathrm{Pu}(\mathrm{m})$ in the $\mathrm{LiCl}-\mathrm{KCl}$ eutectic and reacting in an alumina crucible at $500^{\circ} \mathrm{C}$ for 24 hours while stirred at $75 \mathrm{rpm}$. The resulting dark purple ingot was removed from the crucible, ground in the micromill, and the iron removed using a magnet. A $1.8 \mathrm{~g}$ piece of ${ }^{239} \mathrm{Pu}(\mathrm{m})$ was then added to the collected salt in a new crucible for the second oxidation/reduction step. The crucible was again heated to $500^{\circ} \mathrm{C}$ for 24 hours, but stirring was not possible due to the large piece of Pu metal in the crucible. After cooling, it was found the ingot adhered strongly to the crucible and the crucible had to be broken to remove the remaining piece of $\mathrm{Pu}(\mathrm{m})$ and the salt. After removal, the $\mathrm{Pu}(\mathrm{m})$ piece 
weighed $0.58 \mathrm{~g}$ less, and this was a much greater quantity of $\mathrm{Pu}$ required to react with the remaining $\mathrm{FeCl}_{2}$. Possibilities as to the greater than expected loss of Pu include reaction with the alumina crucible or with Fe to form an intermetallic species. It appears that significant loss of material occurred during the first ${ }^{238} \mathrm{Pu}$ processing as observed by large amounts of salt adhesion and by the occurrence of large chunks of material after the first and second oxidation/reduction steps. Certainly these large pieces contained plutonium metal and there is indication that the large piece observed after the second step may have been partially an intermetallic species due to its slight magnetism. Approximately $2.9 \mathrm{~g}$ of $\mathrm{PuCl}_{3}-\mathrm{LiCl}-\mathrm{KCl}$ salt were recovered from the first batch.

The second batch of salt (experiment 009) was prepared in a similar manner to the first again with a target ${ }^{238} \mathrm{Pu}$ composition of $10 \mathrm{~mol} \%$ in the salt. One difference between processing experiment 008 and 009 was that batch 009 material was stirred during the second oxidation/ reduction step. Observations after the first oxidation/reduction step and magnetic separation of experiment 009 indicated better salt recovery than in the first experiment. However, and similar to experiment 008 , after the second oxidation/reduction step, the salt material strongly adhered to the crucible and stirrer, and there was significant mass loss of the ${ }^{239} \mathrm{Pu}$ metal chunk, more than required for complete reaction with any remaining $\mathrm{FeCl}_{2}$. About $3.1 \mathrm{~g}$ of $\mathrm{PuCl}_{3}-\mathrm{LiCl}-\mathrm{KCl}$ salt was recovered from the second batch.

The last step in the salt preparation process was to mix a quantity of surrogate fission-product salt into the $\mathrm{PuCl}_{3}-\mathrm{LiCl}-\mathrm{KCl}$ salt. This was done to produce a salt mixture that represented actual electrorefiner salt containing fission-product elements with an elevated concentration of ${ }^{238} \mathrm{Pu}$ to allow for the accelerated alpha-decay study. The surrogate eutectic salt was produced to have a composition of surrogate fission products similar to electrorefiner salt that had processed 100 driver-fuel assemblies. The composition and quantities of surrogate fission products are shown in Table 1.

\subsection{Salt/Zeolite Contacting}

The next step in the procedure was to blend the salt mixture with dried zeolite 4A powder (UOP, Houston TX). Quantities of salt and zeolite were added to achieve a salt loading of $3.7 \mathrm{Cl}^{-}$per unit cell of zeolite. The salt was occluded (migration of molten salt into zeolite cages) into the zeolite by contacting at $500^{\circ} \mathrm{C}$ for 5 hours and stirring at $75 \mathrm{rpm}$. After cooling, the material was processed in the micromill. The heating/grinding cycle was repeated three times and a sample of the salt-occluded zeolite measured for free chloride. Free chloride is measured by adding a quantity of salt-occluded zeolite to water, filtering the water, and measuring the $\mathrm{Cl}^{-}$concentration in the water using an ion specific electrode. The free $\mathrm{Cl}^{-}$provides a measure of salt occlusion into the zeolite. Previous work on salt occlusion into the zeolite showed that a free chloride concentration of $0.05 \mathrm{wt} \%$ indicated a high degree of salt occlusion. However, the free chloride measurement of the $\mathrm{PuCl}_{3}$ - $\mathrm{LiCl}-\mathrm{KCl}$ salt contacted zeolite after the three contacting cycles was $0.55 \mathrm{wt} \%$. This value was greater than desired, therefore, two addition contacting cycles were performed at $525^{\circ} \mathrm{C}$ for 12 hours and stirring at $75 \mathrm{rpm}$. The final free chloride value at the end of the five cycles was $0.14 \mathrm{wt} \%$ that meet product specifications for the CWF. The second batch of 
$\mathrm{PuCl}_{3}-\mathrm{LiCl}-\mathrm{KCl}$ salt and zeolite was contacted using the same five cycling steps described above and the final free chloride concentration for the second salt batch was $0.18 \mathrm{wt} \%$.

\subsection{Sample Pellet Production}

After salt/zeolite contacting, a commercial glass binder (Bayer, Baltimore, MD) was mixed with the zeolite for a composition of $75 \mathrm{wt} \%$ salt-loaded zeolite $25 \mathrm{wt} \%$ glass binder. The glass binder composition by mass is approximately $64 \% \mathrm{SiO}_{2}, 20 \% \mathrm{~B}_{2} \mathrm{O}_{3}, 8 \% \mathrm{Al}_{2} \mathrm{O}_{3}, 7 \% \mathrm{Na}_{2} \mathrm{O}$ and minor amounts of $\mathrm{BaO}, \mathrm{K}_{2} \mathrm{O}, \mathrm{CaO}$, and SrO. The total mass for each batch of ${ }^{238} \mathrm{Pu}$ zeolite/glass mixture was $33.207 \mathrm{~g}$ and $33.369 \mathrm{~g}$ (batch 001 and 002), respectively. Portions of each batch were then added to the graphite pin and die assembly of a HUP for processing. The temperature of the HUP was then ramped at $6^{\circ} \mathrm{C} / \mathrm{min}$ to a maximum temperature of $750^{\circ} \mathrm{C}$. Once the temperature had reached $750^{\circ} \mathrm{C}$, a pressure of 5100 psi (34 Mpa) was applied to the die and conditions maintained for four hours. After the processing time, the force was released from the press and the sample allowed to cool. During processing, the zeolite converts to sodalite and the glass, above its softening point, binds the sodalite to form a solid, dense pellet. The transformation of zeolite to sodalite is shown in equation 1. The overall processing scheme is shown in Fig. 1.

$$
\mathrm{Na}_{12}\left(\mathrm{AlSiO}_{4}\right)_{12}+4 \mathrm{NaCl} \rightarrow 2 \mathrm{Na}_{\delta}\left(\mathrm{AlSiO}_{4}\right)_{6} \mathrm{Cl}_{2}
$$

The final HUP pellet diameter was $1.3 \mathrm{~cm}$ with the height, approximately $1 \mathrm{~cm}$, being dependent on the quantity of zeolite/glass mixture added. The quantity of materials used to make each batch of the Pu-salt/zeolite/glass mixture is shown in Table 2, Table 3 lists the overall composition of the pre-processed CWF. Table 4 lists the tests performed on the $18{ }^{238} \mathrm{Pu}-\mathrm{CWF}$ pellets produced from batch 001. The HUP pellets from batch 001 were used exclusively for the accelerated alpha-decay damage study. 


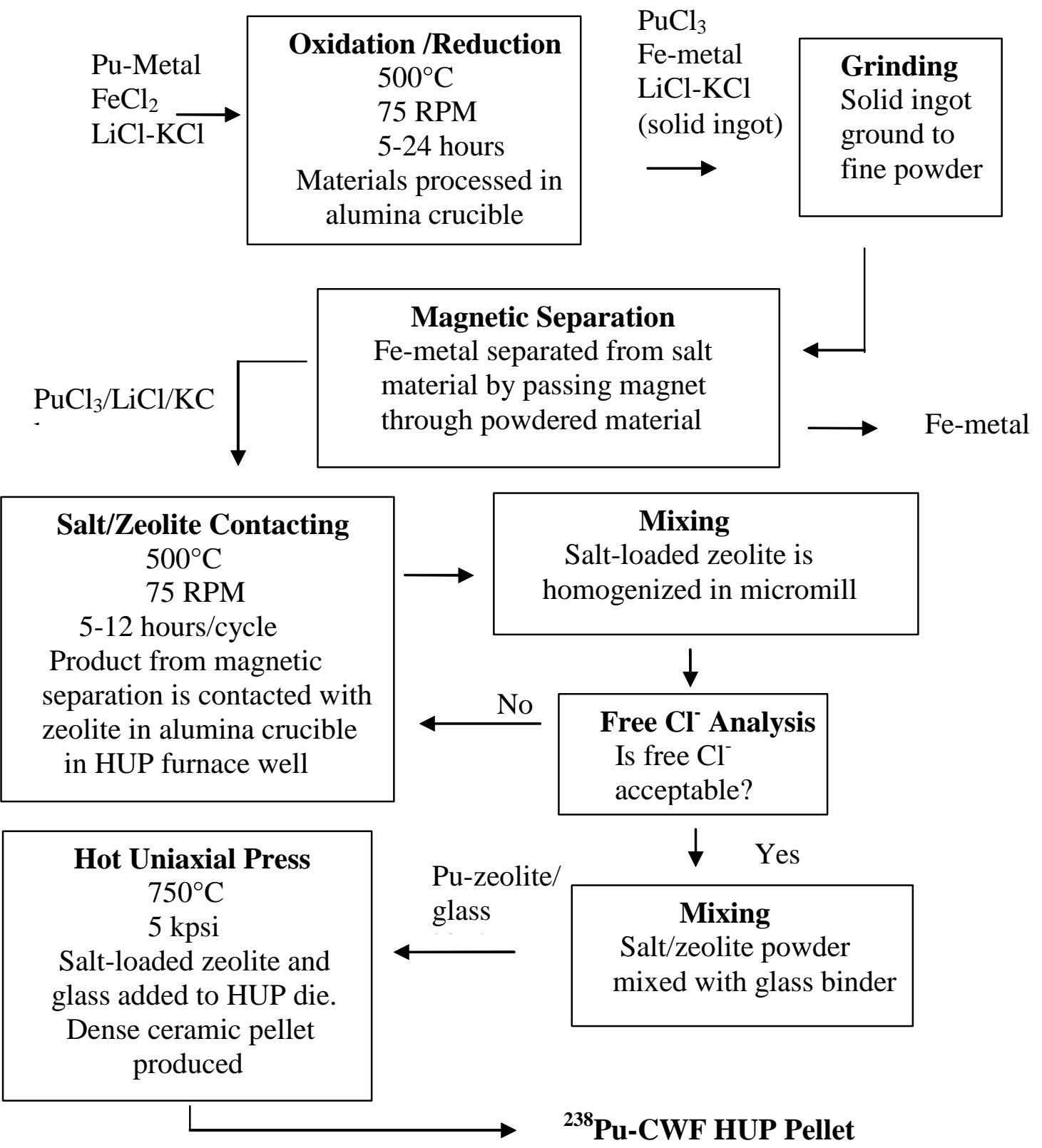

Fig. 1. Schematic of ${ }^{238} \mathrm{Pu}-\mathrm{CWF}$ HUP Pellet Production Process 
Table 2. Quantity of Each Component Used in the Production of ${ }^{238} \mathrm{Pu}$-Salt/Zeolite/Glass Mixtures 001 and 002

\begin{tabular}{|c|c|c|c|c|c|c|}
\hline Batch & $\begin{array}{c}\mathrm{PuCl}_{3} / \\
\mathrm{LiCl} / \mathrm{KCl} \\
\text { Salt (g) }\end{array}$ & $\begin{array}{c}\text { Surrogate } \\
\text { Fission Product } \\
\text { Salt (g) }\end{array}$ & $\begin{array}{c}\text { Dried } \\
\text { Zeolite 4A } \\
(\mathrm{g})\end{array}$ & $\begin{array}{c}\text { Glass } \\
\text { Binder } \\
(\mathrm{g})\end{array}$ & $\begin{array}{c}\text { Estimated } \\
\text { Pu-238 in } \\
\text { Salt } \\
(\mathrm{mole} \%)\end{array}$ & $\begin{array}{c}\text { Estimated } \\
\text { Total Pu in } \\
\text { Salt } \\
(\mathrm{mole} \%)\end{array}$ \\
\hline \hline 001 & 2.859 & 0.572 & 21.474 & 8.302 & 9.6 & 11.7 \\
\hline 002 & 3.088 & 0.461 & 21.478 & 8.342 & 10.0 & 12.4 \\
\hline
\end{tabular}

Table 3. Weight Percent of Each Component in the Pre-Processed CWF Estimated from Process Information

\begin{tabular}{|c|c|c|c|c|c|}
\hline & $\mathrm{PuCl}_{3} / \mathrm{LiCl} / \mathrm{KCl}$ \\
Salt & $\begin{array}{c}\text { Surrogate } \\
\text { Fission Product } \\
\text { Salt }\end{array}$ & Zeolite 4A & $\begin{array}{c}\text { Glass } \\
\text { Binder }\end{array}$ & $\begin{array}{c}\text { Elemental } \\
\text { Pu }\end{array}$ \\
\hline \hline Weight\% & $8.6-9.2$ & $1.4-1.7$ & $64.3-64.7$ & 25.0 & $3.11-3.25$ \\
\hline
\end{tabular}

Table 4. HUP Pellets Produced from Batch 001

\begin{tabular}{|c|l|c|l|c|l|l|l|}
\hline $\begin{array}{c}\text { Pellet } \\
\text { ID }\end{array}$ & $\begin{array}{c}\text { Date } \\
\text { Produced }\end{array}$ & $\begin{array}{c}\text { Mellet } \\
\text { (g) }\end{array}$ & Intended Use & $\begin{array}{c}\text { Pellet } \\
\text { ID }\end{array}$ & $\begin{array}{c}\text { Date } \\
\text { Produced }\end{array}$ & $\begin{array}{c}\text { Pellet } \\
\text { Mass } \\
\text { (g) }\end{array}$ & Intended Use \\
\hline \hline 31 & $10 / 07 / 98$ & 0.35 & XRD & 40 & $11 / 19 / 98$ & 0.97 & PCT \\
\hline 32 & $10 / 16 / 98$ & 0.47 & SEM & 41 & $11 / 23 / 98$ & 0.98 & PCT \\
\hline 33 & $10 / 20 / 98$ & 0.89 & PCT & 42 & $11 / 24 / 98$ & 0.97 & Pulsed flow \\
\hline 34 & $10 / 27 / 98$ & 0.72 & Density & 43 & $11 / 25 / 98$ & 2.98 & PCT \\
\hline 35 & $10 / 27 / 98$ & 0.72 & PCT & 44 & $11 / 30 / 98$ & 2.97 & PCT \\
\hline 36 & $11 / 04 / 98$ & 0.69 & TEM & 45 & $12 / 02 / 98$ & 2.98 & PCT \\
\hline 37 & $11 / 09 / 98$ & 0.96 & PCT & 46 & $12 / 03 / 98$ & 2.96 & PCT \\
\hline 38 & $11 / 17 / 98$ & 0.99 & Pulsed flow & 47 & $12 / 07 / 98$ & 2.97 & PCT \\
\hline 39 & $11 / 18 / 98$ & 0.99 & Pulsed flow & 48 & $12 / 09 / 98$ & 2.94 & PCT \\
\hline
\end{tabular}

$\mathrm{XRD}=\mathrm{x}$-ray diffraction

SEM = scanning electron microscopy

$\mathrm{PCT}=$ product consistency leach test

TEM = transmission electron microscopy

Pulsed Flow $=$ pulsed flow leach test 


\subsection{CHARACTERIZATION AND TESTING OF THE ${ }^{238} \mathrm{Pu}$-LOADED CERAMIC WASTE FORM}

The quantity of plutonium-238 listed in the previous sections was based on the best available information at the time of pellet production. This information was based on process information, not on actual chemical and isotopic analysis. With the recent completion of the actinide concentration and isotopic analysis of the ${ }^{238} \mathrm{Pu}-\mathrm{CWF}$, a better understanding of the actual ${ }^{238} \mathrm{Pu}$ concentration has been obtained. The ${ }^{238} \mathrm{Pu}$ concentration in the CWF material used for this alphadecay study, determined by analytical measurement, is less than previously thought. In the following sections of this report, quantities and alpha-decay dose rates are based on the measured isotopic concentration of ${ }^{238} \mathrm{Pu}$ in the CWF material.

The periodic analysis of the ${ }^{238} \mathrm{Pu}-\mathrm{CWF}$ material was performed for a total of four years. The analysis schedule is summarized in Table 5. The analytical methods used to study the extent of alpha-decay damage on the ${ }^{238} \mathrm{Pu}-\mathrm{CWF}$ include:

1. Microstructure observations performed to monitor phase composition and alteration and radiolytic gas bubble formation after prolonged exposure to alpha decay. These observations were made by scanning electron microscopy (SEM) with energy and wavelength dispersive spectroscopy (EDS and WDS respectively) and transmission electron microscopy (TEM) with electron diffraction and EDS for higher resolution.

2. Chemical durability of the CWF, as a function of alpha-decay cumulative dose was determined by the American Society for Testing and Materials (ASTM C-1285) product consistency test (PCT). In this leaching procedure, powdered CWF material is placed in a leachant (water) for a period of time at elevated temperature. The leachate is then measured for released elements from the CWF.

3. Powder X-ray diffraction (XRD) was used to monitor bulk phase composition and changes to major phase lattice parameters.

4. Density measurements on the CWF are performed by the immersion method using water. Density measurements monitored the CWF for possible macroscopic swelling of the material.

5. Isotopic and partial elemental composition analysis of the ${ }^{238} \mathrm{Pu} \mathrm{CWF}$ was performed to determine the exact $\mathrm{Pu}, \mathrm{U}, \mathrm{Am}$ and $\mathrm{Np}$ isotopic composition of the material. This involved dissolving the CWF material, performing chemical separations to remove isobaric interferences, then measuring the isotopic composition by inductively coupled plasma-mass spectrometry (ICP-MS).

6. Thermal analysis methods (differential thermal and thermomechanical analysis) were to have been applied to the ${ }^{238} \mathrm{Pu} \mathrm{CWF}$, but were not performed due to facility constraints. 


\subsection{EXPERIMENTAL}

\subsection{Scanning Electron Microscopy}

The as-received HUP pellet CL036 was first sliced on a Buehler low speed wafering saw using a diamond blade. The cut was made without lubricant to avoid alteration of soluble phases. The sample was laid flat (un-cut pellet surface down) in a rubber mold, and the mold was filled with epoxy. The epoxy was allowed to polymerize for 23.5 hours, after which the mount was removed from the mold. The sample was polished by hand with dry silicon carbide paper, using 320, 400, 600,800 , and finally 1200 grit. The initial polish with 320 grit completely removed the original sample surface. Between polishing steps, the sample was sonicated in ethanol for $\geq$ one minute, followed immediately by an ethanol rinse. After polishing, and before removal from the glove box, the mounted sample was sonicated three more times in ethanol for $\geq 3$ minutes with clean ethanol rinses after each sonication. After removal from the glove box, loose contamination was still detected on the mount after successive wipes in the radiological fume hood. The contamination was fixed by applying two coats of clear spray acrylic to the sides and bottom of the mount. The sample was then coated first with $25 \AA$ of chromium, then with $200 \AA$ of gold/palladium in the Gatan ion beam coater. The two-layer coating process produced a durable conductive coating that prevented the spread of contamination.

Table 5. Testing Schedule and Corresponding Alpha Decay-Dose Rate for ${ }^{238} \mathrm{Pu}$-Loaded CWF

\begin{tabular}{|c|c|c|c|c|c|c|c|}
\hline $\begin{array}{c}\text { Testing } \\
\text { Schedule } \\
\text { (days) }\end{array}$ & $\begin{array}{c}\text { Cumulated } \\
\text { Alpha-decay } \\
\text { Dose } \\
\text { (a-decays/gram) }\end{array}$ & \multicolumn{6}{|c|}{ Testing Method } \\
\hline \hline 2 & $1.40 \mathrm{E} 15$ & & & & $\mathrm{x}$ & & \\
\hline 21 & $1.46 \mathrm{E} 16$ & & & & $\mathrm{x}$ & & \\
\hline 30 & $2.09 \mathrm{E} 16$ & $\mathrm{x}$ & & & & & \\
\hline 51 & $3.56 \mathrm{E} 16$ & & & & & $\mathrm{x}$ & \\
\hline 52 & $3.63 \mathrm{E} 16$ & & & $\mathrm{x}$ & & & \\
\hline 72 & $5.02 \mathrm{E} 16$ & & & & $\mathrm{x}$ & & \\
\hline 90 & $6.28 \mathrm{E} 16$ & & $\mathrm{x}$ & & & & \\
\hline 97 & $6.77 \mathrm{E} 16$ & & & & $\mathrm{x}$ & & \\
\hline 122 & $8.52 \mathrm{E} 16$ & & & & & $\mathrm{x}$ & \\
\hline 194 & $1.35 \mathrm{E} 16$ & & & & $\mathrm{x}$ & & \\
\hline
\end{tabular}


Table 5. (Contd.)

\begin{tabular}{|c|c|c|c|c|c|c|c|}
\hline \multirow[t]{2}{*}{$\begin{array}{l}\text { Testing } \\
\text { Schedule } \\
\text { (days) }\end{array}$} & $\begin{array}{c}\text { Cumulated } \\
\text { Alpha-decay } \\
\text { Dose } \\
\text { (a-decays/gram) }\end{array}$ & \multicolumn{6}{|c|}{ Testing Method } \\
\hline & & SEM & TEM & PCT & XRD & $\overline{\text { Density }}$ & ICP-MS \\
\hline 240 & 1.67E17 & & & & $\mathrm{x}$ & & \\
\hline 241 & $1.68 \mathrm{E} 17$ & & & & & $\mathrm{x}$ & \\
\hline 260 & 1.81E17 & $\mathrm{x}$ & & & & & \\
\hline 341 & 2.38E17 & & $\mathrm{x}$ & & & & \\
\hline 365 & 2.55E17 & & & & $\mathrm{x}$ & & \\
\hline 383 & 2.67E17 & & & & & $\mathrm{x}$ & \\
\hline 465 & 3.24E17 & & & & & $\mathrm{x}$ & \\
\hline 500 & 3.49E17 & & $\mathrm{x}$ & & & & \\
\hline 764 & 5.33E17 & & & $\mathrm{x}$ & & & \\
\hline 778 & 5.43E17 & & & & & $\mathrm{x}$ & \\
\hline 792 & 5.53E17 & & & & $\mathrm{x}$ & & \\
\hline 889 & $6.20 \mathrm{E} 17$ & & & & & $\mathrm{x}$ & \\
\hline 967 & $6.75 \mathrm{E} 17$ & & & & & $\mathrm{x}$ & \\
\hline 992 & 6.92E17 & & & & $\mathrm{x}$ & & \\
\hline 1095 & 7.64E17 & $\mathrm{x}$ & & & & & \\
\hline 1098 & 7.66E17 & & & & & $\mathrm{x}$ & \\
\hline 1137 & 7.94E17 & & & & $\mathrm{x}$ & & \\
\hline 1197 & 8.36E17 & & & & & $\mathrm{x}$ & \\
\hline 1217 & 8.49E17 & & & & $\mathrm{x}$ & & \\
\hline 1274 & 8.89E17 & & & & & $\mathrm{x}$ & \\
\hline 1393 & 9.72E17 & & & & & $\mathrm{x}$ & \\
\hline 1415 & 9.88E17 & & & & $\mathrm{x}$ & & \\
\hline 1460 & 1.02E18 & & $\mathrm{x}$ & & & & \\
\hline 1471 & 1.03E18 & & & $\mathrm{x}$ & & & \\
\hline 1503 & 1.05E18 & & & & $\mathrm{x}$ & & \\
\hline 1505 & $1.05 \mathrm{E} 18$ & & & & & $\mathrm{x}$ & \\
\hline 1716 & $1.20 \mathrm{E} 18$ & & & & & & $\mathrm{x}$ \\
\hline
\end{tabular}


The Zeiss DSM960A digital scanning electron microscope was used to gather these data. The DSM960A is equipped with secondary and back scattered electron detectors, as well as Oxford Instruments energy and wavelength dispersive X-ray detectors. The spectrometers are driven by ISIS Series 300 software, version 3.2, Winspec version 3.1 software is also available to drive the wave length dispersive spectrometer. The instrument was operated at an accelerating voltage of $20 \mathrm{KV}$, and an emission current of $40 \mu \mathrm{A}$. Experimental conditions were closely monitored during electron microscopy analysis to prevent or distinguish electron beam damage to the sample.

\subsection{Transmission Electron Microscopy}

Transmission electron microscopy samples were prepared using a modified dimpling-ion milling method. The ceramic waste form samples with and without radiation damages were broken into small pieces. The small segments were then bonded inside a copper ring ( $3 \mathrm{~mm}$ in diameter, $\sim 1 \mathrm{~mm}$ in thickness) using the Gatan G-1 epoxy. After curing the mixture at $120^{\circ} \mathrm{C}$ for $15 \mathrm{~min}$, the disc shape sample was ground using silicon carbide abrasive papers to about $100 \mu \mathrm{m}$ in thickness. A Gatan Dimple Grinder and cubic boron nitride pastes were used to form a dimple at the center of the disc. The center of the dimple had a thickness less than $30 \mu \mathrm{m}$. A Gatan Precision Ion Polishing System was used to further thin down the dimpled sample until perforation. A $50 \AA$ conductive carbon coating was applied on the ion-milled sample using a Gatan Ion Beam Coater. TEM characterization was conducted using a JEOL 2010 transmission electron microscope operated at $200 \mathrm{keV}$. Energy-dispersive X-ray spectra were obtained using an Oxford Instruments EDS system. The following outline shows the TEM specimen preparation:

1. Crushing pellets into small segments (less than $500 \mu \mathrm{m}$ )

2. Mixing with $\mathrm{G}-1$ epoxy

3. Curing at $120^{\circ} \mathrm{C}$ for 15 minutes

4. Grinding (1200 grit finish)

5. Dimpling

6. Ion milling (3.5 keV, Argon)

7. Ion beam coating ( $\sim 5 \mathrm{~nm}$ carbon)

8. TEM characterization

a. Bright field image

b. Selected area electron diffraction

c. Energy dispersive spectroscopy

\subsection{Product Consistency Test}

Chemical durability of the CWF is determined by the product consistency test as per ASTM method 1285 [15]. This test involves grinding the material to a specific particle size range, then placing the powder in demineralized (DM) water leachant at a specific temperature for a set period of time $\left(90^{\circ} \mathrm{C}\right.$ for 7 days). After the leaching period, the leachate is analyzed for released elemental constituents of the waste form. For the results described here, the ASTM PCT-B test was performed in which a smaller particle size of approximately $60 \mathrm{~mm}$ diameter material was used. This allowed for the use of powdered ${ }^{238} \mathrm{Pu}$-loaded CWF material used previously for the 
initial PCT at the start of the alpha-decay test period. Preparation of the ${ }^{238} \mathrm{Pu}$-loaded CWF material for the PCT was accomplished at the Hot Fuel Examination Facility (HFEF). For this test, the previously powdered material from HUP Pellets CL033, -35, -37, -40, -41, and pellets 42 through 47, were re-sieved and material collected from the smaller -200 to +325 sieves (75 to $45 \mathrm{~mm}$ diameter). Once the powder was collected, preparation then involved washing the powder, loading weighed quantities of the powder into stainless steel test vessels and adding known quantities of leachant to the vessels. The volume of leachant added resulted in a ratio of sample surface area to leachant volume of $2000 \mathrm{~m}^{-1}$. Glass approved reference materials (ARM) with leachant were also prepared in the same way as the CWF PCT samples, as well as blank test solutions in which only leachant was added to test vessels. The vessels were then placed in an oven at $90^{\circ} \mathrm{C}$ for seven days. At the end of the test, the vessels were opened and the leachate was filtered $(0.45 \mu \mathrm{m})$ and collected. Each vessel was then washed with DM water to remove the CWF powder, and a 2 vol\% nitric acid solution was added to each vessel to the same approximate volume as the original leachate solution. The vessels with acid strip solution were then placed in the oven at $90^{\circ} \mathrm{C}$ for 18 hours. This acid strip solution removes any adsorbed material from the vessel walls. Finally, the original PCT powder water wash, filtered leachate solutions, acid strip solutions, and the filtered ARM glass standard leachates and blank solutions were analyzed by either inductively coupled plasma-mass spectrometry, or inductively coupled plasma-atomic emission spectroscopy for leached elemental CWF constituents. Collodial particles in the leachate smaller than $0.45 \mu \mathrm{m}$ and that were not solubilized by the acid stabilizer solution would not contribute to the measured elemental release of the CWF.

\subsection{Density Measurement}

Density measurements are performed periodically on HUP pellet CL034 using an immersion technique. Decrease in density can be attributed to macroscopic swelling due to radiation damage to the bulk material. The method involves first weighing the sample then measuring the buoyancy weight of the sample in water. The density is calculated from the formula:

$$
\text { Density = sample weight/sample buoyancy } \mathrm{x} \text { density of water (at a given temperature) }
$$

The density of an aluminum standard, and a non-plutonium loaded HUP CWF pellet is measured along with the sample to determine the uncertainty of the measurements and as a calibration check. The measurements are performed in an air atmosphere glove box using a OHAUS, model AP250D analytical balance.

\subsection{X-Ray Diffraction}

Sample preparation for XRD measurement involved grinding a piece of CWF HUP pellet CL031 to a fine powder. The powder was then sieved through a $125 \mathrm{~mm}$ sized screen. Approximately $2 \mathrm{wt} \%$ of a National Institute for Standards and Technology (NIST) traceable $\mathrm{LaB}_{6}$ standard reference material (SRM 660) powder was then mixed with the CWF powder. The $\mathrm{LaB}_{6}$ standard was added to determine the diffractometer zero parameter and other instrument constants during pattern structural refinement. The powder was then placed on a zero-background quartz sample holder and placed in the XRD containment chamber. These operations were performed inside an air glove box. After the chamber was sealed, the containment chamber was removed from the 
glove box, decontaminated, then ready for analysis. Powder XRD analyses were performed approximately every six months on the same sample in the containment chamber using a Scintag X1 (Thermal ARL, Franklin, MA) diffractometer with theta-theta configuration. The incident radiation was $\mathrm{Cu} \mathrm{K}$ x-rays with a x-ray tube voltage of $45 \mathrm{kV}$ and current of $40 \mathrm{~mA}$. The instrument scan rate was $0.5^{\circ} / \mathrm{min}$. Major phase composition was confirmed using the Scintag DMSNT search match routine software. Pattern Refinement of the XRD pattern was performed with General Structure Analysis System (GSAS) software [16] and quantitative phase analysis of the CWF was performed using the SIROQUANT software package [17].

\section{$4.6{ }^{238} \mathrm{Pu}$ CWF Isotopic Measurement}

Isotopic measurement of the actinide and surrogate-fission product content in the ${ }^{238} \mathrm{Pu} \mathrm{CWF}$ first required dissolution of the material. The sample obtained for this measurement came from the same powdered material used for the PCT. The powdered PCT material was transferred into the main cell of HFEF where a small quantity, $0.218 \mathrm{~g}$, was placed in a clean, $100 \mathrm{~mL}$ Teflon $^{\mathrm{TM}}$ container and capped. The container was then transferred to the Analytical Laboratory (AL) and placed in an air atmosphere glove box for dissolution. The advantage of using the PCT material for chemical analysis was that it represents a good homogenous sample from the original batch 1 $\mathrm{Pu}$-salt/zeolite/glass material. The material was inspected in the glove box to insure that the powder had remained in the bottom to the container. The dissolution proceeded using an established ANL-West AL procedure for CWF dissolution. This involved the addition of $7 \mathrm{~mL}$ of a 1:1 mixture of concentrated $\mathrm{HCl}: \mathrm{HNO}_{3}$ solution with 2 vol\% hydrofloric acid (HF) to the Teflon $^{\text {TM }}$ container. The mixture was heated to a low boil. The dissolution proceeded slowly and required the addition of two more acid mixture volumes. After the third acid mixture had boiled for approximately $20 \mathrm{~min}$, the solution was allowed to cool. Even after this aggressive digestion, a very fine, black material was still observed in the solution. The solution was quantitatively transferred to a clean polyethylene bottle with de-ionized water. The final volume of the solution weighted $35.7200 \mathrm{~g}$. When dissolving $\mathrm{Pu}$ in the presence of $\mathrm{F}^{-}$ion, the possibility exists that a $\mathrm{PuF}_{\mathrm{x}}$ precipitate can form. Addition of a boric acid ethylenediamine teta-acetic acid (EDTA) mixture will then bring the Pu back into solution. Close visual inspection of the undissolved material in the dissolver solution indicated that the material was not a $\mathrm{PuF}_{\mathrm{x}}$ precipitate, normally a purple or brown color, but a very finely divided black material, most likely an impurity or crucible material originally present in the sample. It was decided to attempt the analysis without addition of the boric acid EDTA mixture and that if the Pu concentration was very low, the second acid mixture would be added at a later time. From the dissolver solution, a 1:1000 dilution was made into a 1 vol\% Optima ${ }^{\circledR} \mathrm{HNO}_{3}$ diluent solution. An aliquot of this solution was then used for separation and measurement.

The determination of actinides by ICP-MS is complicated by the isobaric interferences associated with the unit mass resolution of the mass filter. Examples of interferences include $\mathrm{m} / \mathrm{z}{ }^{238} \mathrm{U} /{ }^{238} \mathrm{Pu},{ }^{1} \mathrm{H}^{238} \mathrm{U} /{ }^{239} \mathrm{Pu}$, and ${ }^{241} \mathrm{Pu} /{ }^{241} \mathrm{Am}$ among others. To overcome these interferences, either a means of separating the interfering elements from each other is necessary or the application of the analysis to a higher resolution instrument is needed. Traditionally, the separations required for analysis of the actinides would be performed on a hand packed column 
of various commercially available resins, relying on gravity to move the liquid through the separating media. This has several drawbacks for analysis of samples by ICP-MS. First, it is difficult to achieve complete recovery of all the liquid material put into the system. Since ICP-MS has very high sensitivity for the actinides, samples are typically diluted before analysis. For quantitative determination of the actinides, it is vitally important to maintain accurate and precise dilution values. Second, the drip column technology is very technique dependent. Recoveries for spiked samples can vary drastically from person to person. Lastly, the columns used for the separation are used once and disposed of, while also requiring not insignificant amounts of additional liquids to be used for stripping. The additional materials require radioactive material disposal or disposition.

The work performed here utilized a gas pressurized extraction cell to separate the actinides. The resin material may be the same as the gravity driven system, but nitrogen is used to push the liquid through the column. This extraction system offers numerous advantages which include:

- Quantitatively recovering liquid put in system,

- $\quad$ Tailor column size and resins for varying measurement requirements,

- $\quad$ More precise dilutions,

- $\quad$ Columns are re-usable,

- $\quad$ Requires less liquid to complete separation,

- $\quad$ Offers faster extraction times,

- Has the potential for automated hot cell/glovebox operation,

- $\quad$ Can use system for separation or preconcentration experiments, and

- $\quad$ Both online and fraction collection sample preparation.

A VG elemental ICP-MS (Thermo ARL, Franklin, MA) was used for these experiments. This instrument incorporates a one half glovebox, to shield users from radiation fields while analyzing radioactive samples. Typical operating conditions are given in Table 6.

Table 6. ICP-MS Operating Conditions Used For Isotopic Analysis of ${ }^{238} \mathrm{Pu}$ CWF Dissolver Solution

\begin{tabular}{|l|l|}
\hline ICP-MS & VG PQ3-Nuclide (1/2 glovebox) \\
\hline Forward power & $1450 \mathrm{~W}(<5 \mathrm{~W}$ reflected $)$ \\
\hline $\begin{array}{l}\text { Vacuum pressures (expansion, } \\
\text { analyzer) }\end{array}$ & $1.3,9 \mathrm{E}-7 \mathrm{mbar}$ \\
\hline Ion lenses & Tuned on $\mathrm{m} / \mathrm{z} 114.9(160 \mathrm{M} / \mathrm{ppm})$ \\
\hline
\end{tabular}


Table 6. (Contd.)

\begin{tabular}{|l|l|}
\hline Gas flows (coolant, neb., aux) & $13.3,0.700,0.8 \mathrm{~L} / \mathrm{min}$ \\
\hline Data acquisition & Peak hopping 3 pts/peak \\
\hline ICP-MS & VG PQ3-nuclide (1/2 glovebox) \\
\hline Reagents & $\begin{array}{l}\text { Ultra-pure acids, plasma grade } \\
\text { water }\end{array}$ \\
\hline Standards & Spex standards (10 ppm) \\
\hline Dissolution of Pu-CWF & $\begin{array}{l}\text { Conc. HCl/HNO3, 0.5 M HF-heat } \\
\text { to near boil for 2-3 hours }\end{array}$ \\
\hline Extraction resin & $\begin{array}{l}\text { U-TEVA, TEVA eichrom } \\
\text { technologies }\end{array}$ \\
\hline
\end{tabular}

The gas pressurized extraction system consists of a series of 4-way slider valves utilizing Teflon tubing to connect the flow paths between the valves. The schematic drawing for the experimental apparatus is shown in Fig. 2. Solenoid valves are used to change the position of the slider valves, allowing for the loading of the sample loop $(203 \mathrm{~mL})$ and the application of the sample to the column. This gas pressurized extraction system was designed to utilize the equipment used in the ICP-MS glovebox. However, these experiments were performed in a hood utilizing a mock up of the system to be installed in the ICP-MS glovebox.

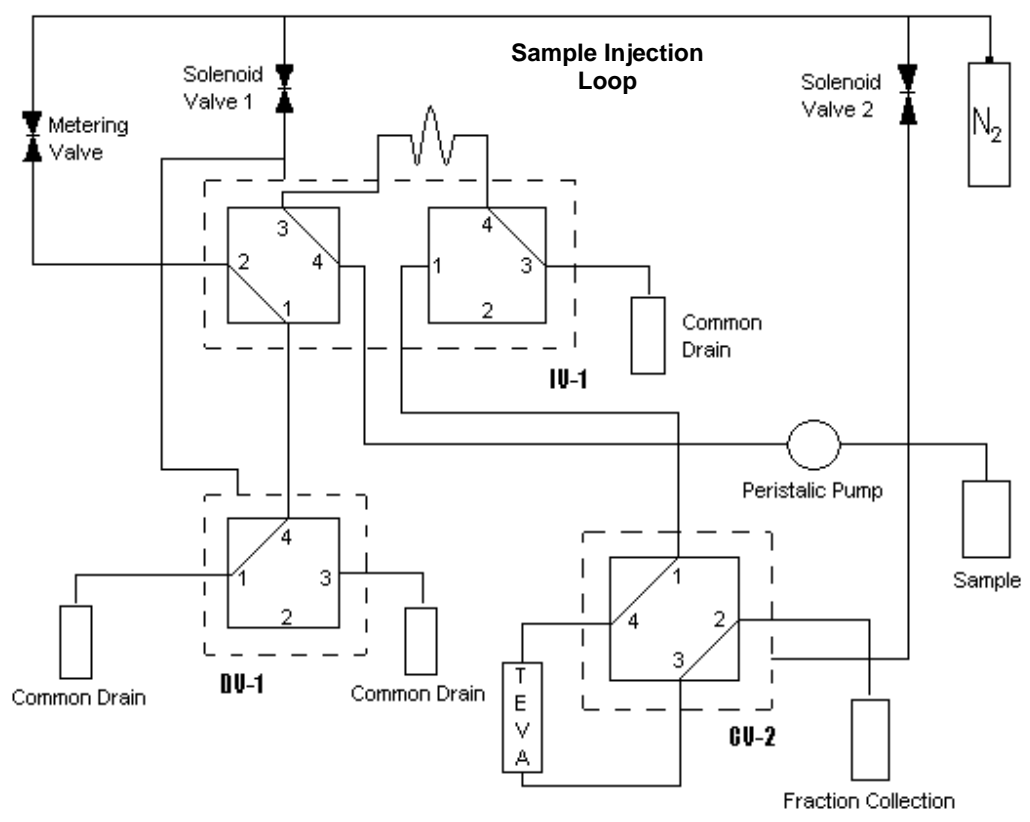

Fig. 2. Schematic of Actinide Extraction System 
The column used for the actinide separation experiments, and shown schematically in Fig. 2, consisted of a 3 inch piece of 1/16 in. outer diameter tubing with a 0.030 in. inner diameter. The internal volume of the column without resin material is approximately $35 \mathrm{~L}$. To this column $77 \mathrm{mg}$ of TEVA Resin (Eichrome Inc) was added. TEVA resin is designed to allow the uranium and americium to pass through the column, while capturing the $\mathrm{Pu}$ (IV). If necessary, the oxidation state of plutonium can be fixed with the use of sodium nitrite and titanium chloride. However, no oxidation state adjustments have been needed for the development work of the system testing CRM 126 (a Pu certified reference material). The samples prepared for this work were done by using fraction collection.

\subsection{RESULTS AND DISSCUSION}

\subsection{Microstructure}

The microstructure of the ${ }^{238} \mathrm{Pu}$-loaded CWF is very similar to the reference (non-Pu loaded) CWF and consists of 5 to 20-micron diameter sodalite regions surrounded by the glass binder. Plutonium is found primarily as $\mathrm{PuO}_{2}$ in the glass areas between sodalite regions; however, TEM has also observed two, very minor Pu silicate phases in the ${ }^{238} \mathrm{Pu}$-loaded CWF that have not been observed in the actual CWF containing approximately $0.1 \mathrm{wt} \% \mathrm{Pu}$. The minor Pu silicate phases are possibly observed in the ${ }^{238} \mathrm{Pu}$ CWF material, rather than the typical CWF material, due to the greater Pu loading of samples used in this study [18]. SEM analysis also observed an ironplutonium minor phase, probably an artifact of salt preparation. High resolution microscopy has also observed bubbles and/or voids in both the sodalite and glass phases of the ${ }^{238} \mathrm{Pu} \mathrm{CWF}$ and the origin of these features is currently unknown. Of particular interest is the observation that no microcrack formation or phase debonding from the matrix material has occurred after four years of alpha-decay damage. This is significant in that these material defects are what typically lead to the greatest degradation to the waste form after prolonged exposure to radiation decay, due to increased surface area of the material in contact with ground water [13].

\subsubsection{SEM Analysis}

Periodic analysis of the ${ }^{238} \mathrm{Pu}$-loaded CWF by SEM indicates no variation to the microstructure or elemental distribution of phases, at the micron-size level, in the waste form after three years exposure, or a cumulative dose of $7.6 \times 10^{17}$ alpha decays/g as shown in Fig. 3. 

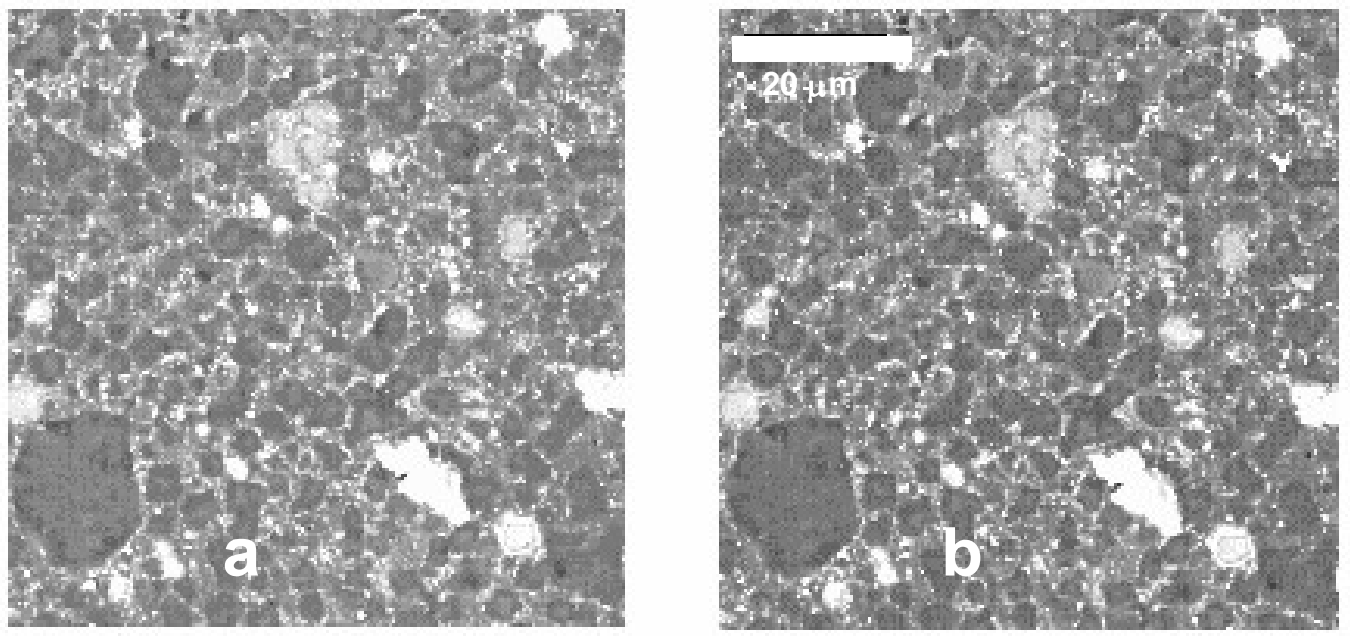

Fig. 3. SEM Analysis of Selected Region of the ${ }^{238}$ Pu-loaded CWF Sample (a) Shortly After the HUP Pellet was Produced and (b) After Three Years or $1.1 \times 10^{18}$ alpha decays/g Cumulated Dose (no change to the sample is observed, the micrograph shows sodalite as dark areas, glass as gray areas and $\mathrm{PuO}_{2}$ as the white areas)

Initial characterization by SEM showed that the sample appeared very similar to previously examined ${ }^{239} \mathrm{Pu}$ loaded HUP pellets in the initial survey [19]. Intergranular glassy regions high in silicon and giving a high back scattered electron signal (from plutonium-rich inclusions) separated aluminosilicate grains with energy dispersive X-ray spectra typical of salt occluded sodalite. These two phases comprised the bulk of the sample. Porosity was comparable to previously examined HUP samples. Representative sample microstructure is illustrated by the images in Fig. 4. Occasional iron and plutonium-containing phases were also observed as irregular inclusions several microns in size, along with an aluminosilicate phase that was unusually rich in plutonium. Rare earth containing inclusions sub-micron to micron in size also containing plutonium were observed as well. Figure 5 is a back scattered electron image of one such inclusion. The rare earth constituents of this inclusion were identified by EDS as cerium and neodymium. 

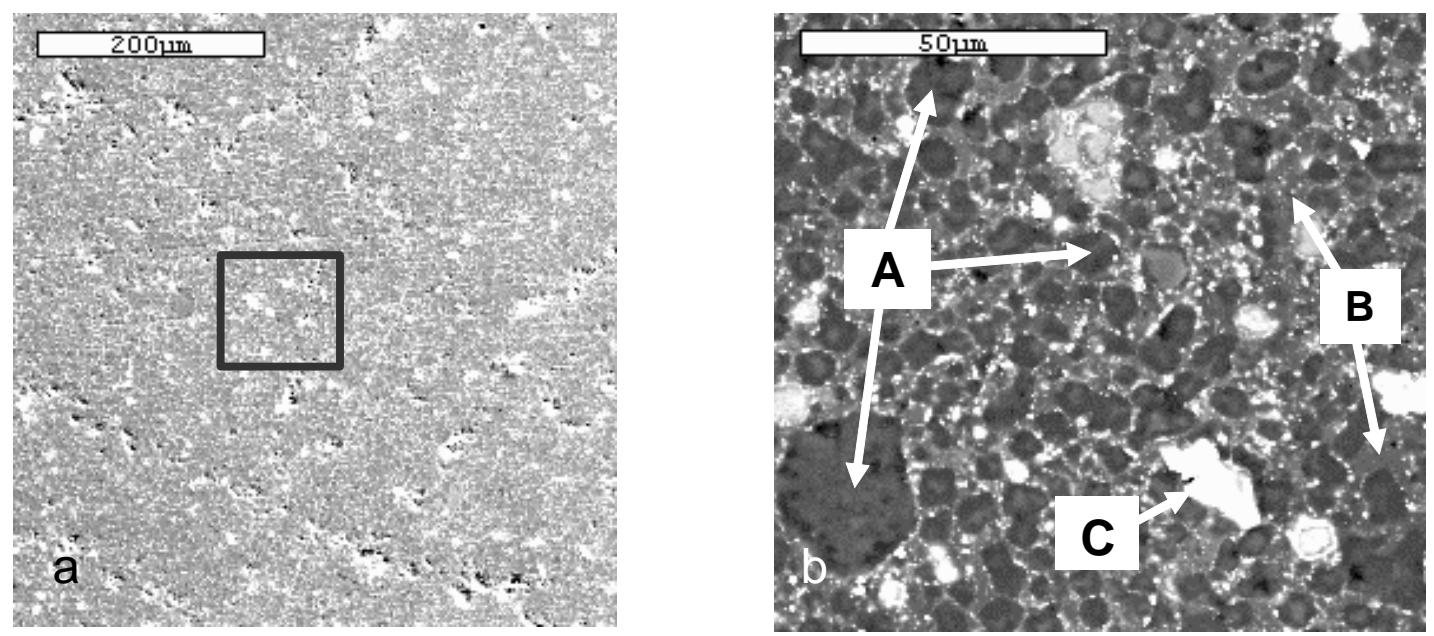

Fig. 4. (a) Low Magnification Secondary Electron Image Showing Porosity and Overall Microstructure (the approximate area imaged in (b) is shown by the box) (b) Higher Magnification Back Scattered Electron Image Showing Details of the Microstructure $\left(\mathrm{A}=\right.$ glassy phase, $\mathrm{B}=$ sodalite grain, $\mathrm{C}=\mathrm{PuO}_{2}$ inclusion)

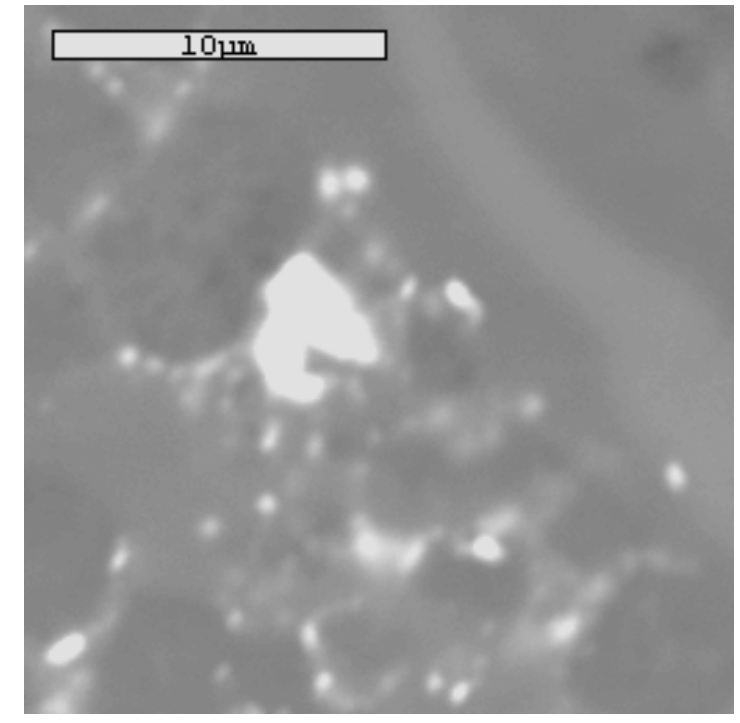

Fig. 5. Back Scattered Electron Image of a Relatively Large Rare Earth (Ce and Nd) Inclusion (bright object near center of image, the rare earth inclusions in this sample also contained plutonium)

X-ray maps were acquired from a representative region of the sample to illustrate the composition of the microstructure. This region was selected to show examples of all the phases observed except the rare earth containing phases, which were too small to observe in X-ray maps at the same magnification. Selected results from the X-ray maps are shown in Fig. 6. Energy dispersive point spectra were obtained to quantify phase compositions by focusing the electron beam to a point on the various phases identified in the X-ray map region. The locations of these 
points are shown in Fig. 6a. Five distinct phases were identified in Fig. 6. The darkest areas in Fig. 6a were identified as sodalite based on compositions determined from analyses of EDS data. A small amount of plutonium was also detected, although TEM results indicate that this plutonium is actually present as small crystals of $\mathrm{PuO}_{2}$ tens of nanometers in size.

These nanocrystals are too small to resolve by this method, but can be resolved by TEM. Sodalite regions can be identified by the high aluminum concentration as shown in Fig. 6c. The two brightest areas in the upper right and upper left of Fig. 6a were iron-plutonium phases, probably resulting from the use of iron chloride to oxidize plutonium metal during preparation of the salt. The other very bright areas in Fig. 6a are $\mathrm{PuO}_{2}$ inclusions. The iron-plutonium and $\mathrm{PuO}_{2}$ phases can be differentiated by comparing Fig. $6 \mathrm{~b}$ and Fig. 6e. The medium-dark regions in Fig. 6a were identified as glassy regions. Glassy regions are characterized by higher silicon concentrations compared to the sodalite regions. In Fig. 6d, the contrast in silicon concentrations between sodalite and glassy regions has been enhanced by subtracting the aluminum signal from Fig. 6c from the silicon signal. The medium bright regions in Fig. 6a were identified as a plutonium-rich aluminosilicate phase resembling sodalite in composition. The high plutonium content of this phase is illustrated in Fig. 6b.

Data from like phases identified in Fig. 6 were batch analyzed to determine average compositions, thereby reducing the influence of anomalies arising from microstructural effects. An example of a microstructural anomaly in such data is when analysis is unknowingly performed on a thin feature. The electron beam can then excite X-ray emission from an underlying phase, resulting in extraneous data. Since there is no evidence to indicate that any of the microstructural features of this material are inherently plate-like or needle-like, it is assumed that such thin spots are encountered randomly. Therefore, batch analysis of data obtained from a number of different locations should reduce the influence of such anomalous data on the averaged results. 

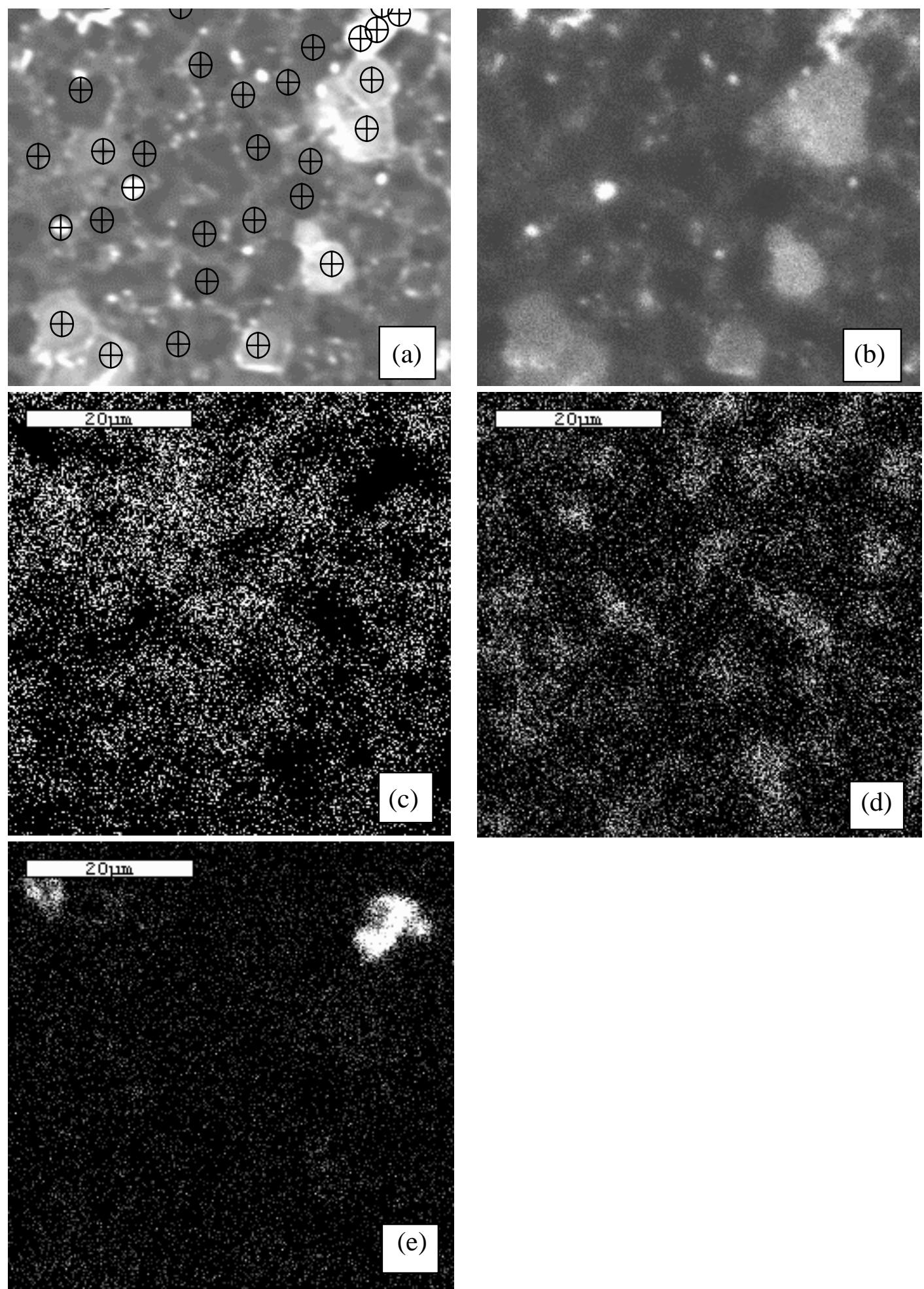

Fig. 6. Results from X-ray Maps of a Representative Region of HUP Pellet CL036. (a) Back Scattered Electron Image of the Mapped Region Also Showing Locations of Point Spectra Used to Quantify Phase Compositions (b) Plutonium $\mathrm{M}_{\mathrm{a}}$ X-ray WDS Map (c) Aluminum $\mathrm{K}_{\mathrm{a}} \mathrm{X}$-ray EDS Map (d) Silicon $\mathrm{K}_{\mathrm{a}}$ X-ray Map Processed by Subtracting the $\mathrm{Al} \mathrm{K}_{\mathrm{a}}$ Signal to Enhance Silicon Rich (glassy) Regions (e) Iron $\mathrm{K}_{\mathrm{a}} \mathrm{X}$-ray Map 
Plutonium concentrations were determined by WDS using an inclusion within the sample (shown in Fig. 7) as a reference. X-ray powder diffraction results indicated the presence of cubic $\mathrm{PuO}_{2}$ within the sample, and the spot on the inclusion indicated in Fig. 7 gave a reasonably "clean" EDS spectrum of plutonium and oxygen (see Fig. 8). This spot was used to calibrate the WDS system for plutonium, assuming the ideal $\mathrm{PuO}_{2}$ stoichiometry.

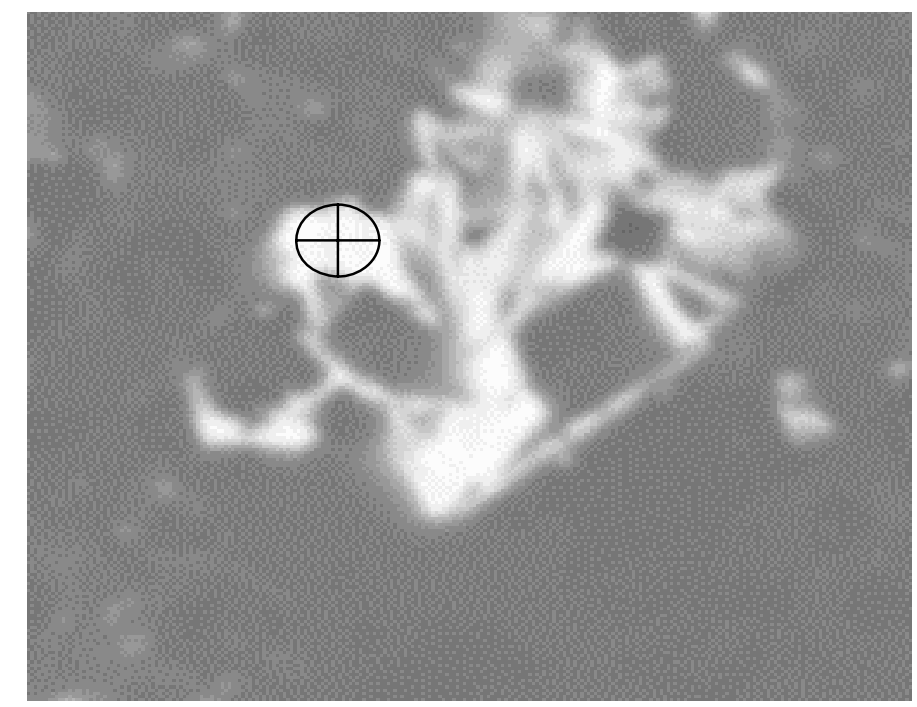

Fig. 7. Back Scattered Electron Image of the $\mathrm{PuO}_{2}$ Inclusion Used to Calibrate the WDS System for Quantitative Analysis of Plutonium (the spot used to calibrate the system is indicated by the cross hairs)

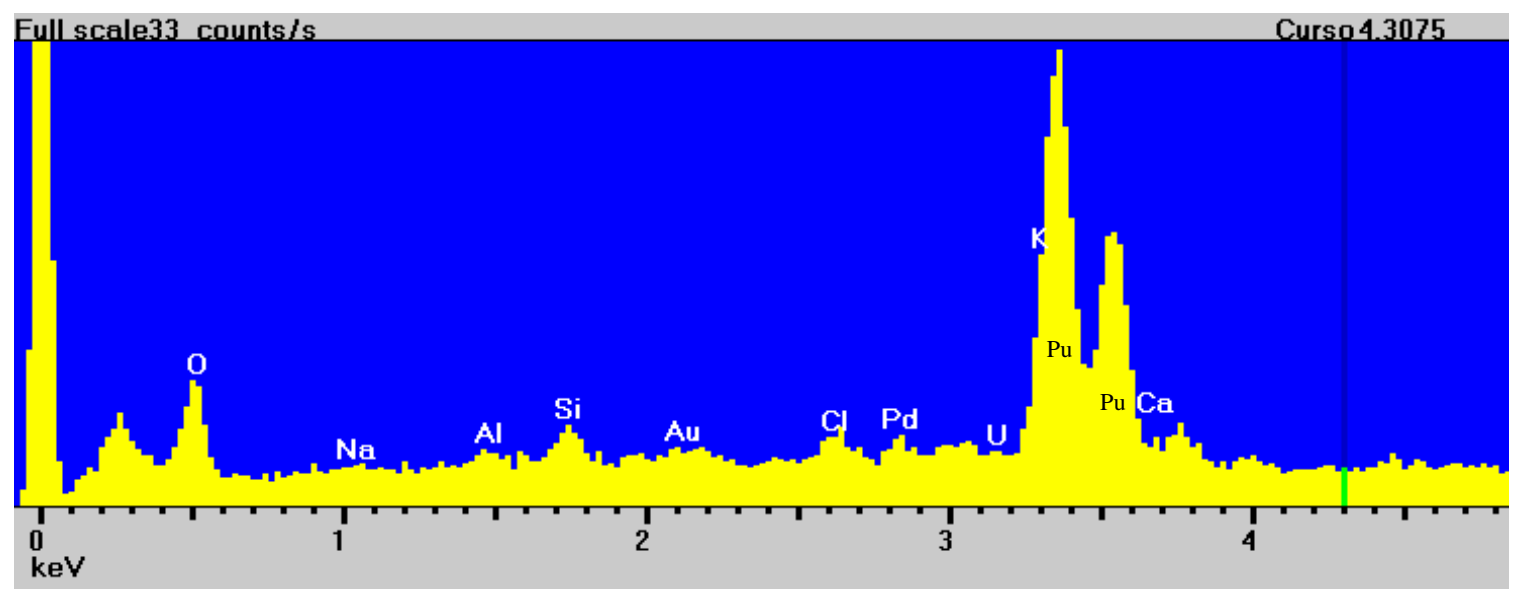

Fig. 8. Energy Dispersive X-ray Spectrum from the Spot Indicated in Fig. 7 (the major $\mathrm{M}_{\alpha}$ and $\mathrm{M}_{\beta}$ plutonium peaks are seen at 3.3 and $3.5 \mathrm{KeV}$, respectively. 
The two strongest peaks (unlabeled) in the spectrum are plutonium $\mathrm{M}$ lines, which, along with the oxygen peak, identifies this spot as $\mathrm{PuO}_{2}$. $\mathrm{Si}, \mathrm{Al}$, and $\mathrm{Cl}$ peaks are considered negligible. $\mathrm{Au}$ and Pd peaks are from the gold/palladium coating applied to the sample to impart electrical conductivity. The peak at $0.28 \mathrm{KeV}$ is from carbon, a ubiquitous environmental contaminant.

The results of batch analyses of the sodalite, glass, and high-plutonium aluminosilicate phases identified in Fig. 6 are shown in Table 7. Note that the composition of the high plutonium aluminosilicate phase nominally resembles sodalite, except that the concentration of potassium is unusually high. The high potassium content in the high plutonium aluminosilicate may be related to the $\mathrm{K}_{2} \mathrm{PuCl}_{6}$ phase that is present in the salt after oxidation of the plutonium metal. However, a simple occlusion mechanism cannot explain the increased potassium content, because there is no corresponding increase in chlorine concentration. In addition, electron diffraction in TEM indicates a crystal structure which is inconsistent with sodalite.

Table 7. Results of Batch Analysis of Sodalite, Glass, and High-Pu Aluminosilicate Phases Identified in Fig. 6

\begin{tabular}{|l|c|c|c|c|c|c|c|}
\hline \multicolumn{1}{|c|}{ Sodalite } & $\begin{array}{c}\mathrm{Wt} \% \\
\mathrm{O}\end{array}$ & $\begin{array}{c}\mathrm{Wt} \% \\
\mathrm{Na}\end{array}$ & $\begin{array}{c}\mathrm{Wt} \% \\
\mathrm{Al}\end{array}$ & $\begin{array}{c}\mathrm{Wt} \% \\
\mathrm{Si}\end{array}$ & $\begin{array}{c}\mathrm{Wt} \% \\
\mathrm{Cl}\end{array}$ & $\begin{array}{c}\mathrm{Wt} \% \\
\mathrm{~K}\end{array}$ & $\begin{array}{c}\mathrm{Wt} \% \mathrm{Pu} \\
(\mathrm{WDS})\end{array}$ \\
\hline \hline Min: & 43.2 & 0.9 & 18.3 & 22.6 & 5.4 & 0.5 & 0.75 \\
\hline Max: & 48.9 & 2.0 & 21.1 & 25.8 & 8.6 & 2.5 & 3.39 \\
\hline Mean: & 45.9 & 1.5 & 19.8 & 24.2 & 7.3 & 1.4 & 1.81 \\
\hline StdDev: & 1.7 & 0.4 & 1.0 & 1.2 & 1.1 & 0.6 & 0.98 \\
\hline Glass & & & & & & & \\
\hline Min: & 46.8 & 0.6 & 9.1 & 26.5 & 2.3 & 2.4 & 1.84 \\
\hline Max: & 53.4 & 1.6 & 16.0 & 31.6 & 6.2 & 3.7 & 3.34 \\
\hline Mean: & 50.0 & 1.2 & 12.5 & 29.4 & 3.9 & 3.2 & 2.56 \\
\hline StdDev: & 1.9 & 0.3 & 1.9 & 1.7 & 1.2 & 0.5 & 0.57 \\
\hline High Pu & & & & & & & \\
\hline Aluminosilicate & & & & & & & \\
\hline Min: & 46.8 & 0.4 & 16.88 & 20.0 & 4.7 & 4.3 & 12.67 \\
\hline Max: & 51.0 & 1.1 & 19.3 & 22.8 & 7.3 & 6.9 & 15.85 \\
\hline Mean: & 48.7 & 0.8 & 18.2 & 21.0 & 6.1 & 5.4 & 14.26 \\
\hline StdDev: & 1.4 & 0.39 & 1.0 & 1.0 & 1.0 & 1.1 & 2.25 \\
\hline
\end{tabular}

Note: Plutonium concentrations were determined by WDS. All other values were determined by standardless analyses of EDS data. Plutonium concentrations in sodalite and glass phases are from finely disbursed nanocrystals of $\mathrm{PuO}_{2}$ 
Transmission electron microscopy shows that the plutonium content of glass and sodalite phases is largely attributed to very small (tens of nanometers) $\mathrm{PuO}_{2}$ crystals. Because of small $\mathrm{PuO}_{2}$ crystals within the beam activation volume, the plutonium concentrations indicated in Table 7 for these phases are likely to be higher than is actually the case, although the minimum may be a reasonable estimate. These $\mathrm{PuO}_{2}$ crystals are found in TEM distributed within the glass regions, as well as occasionally at grain boundaries within sodalite regions. The plutonium lines observed in X-ray fluorescence spectra from the SEM apparently arise from these nanoscale $\mathrm{PuO}_{2}$ crystals, since X-ray fluorescence spectra from the TEM showed little or no plutonium dissolved in the glass or occluded in the sodalite. It is impossible to resolve such features during X-ray analysis in the SEM because the activation volume is comparatively large. As a result, the analytical results reported in Table 7 represent a "bulk" analysis, albeit of a very small volume of material. The high plutonium aluminosilicate, however, appears from TEM to consist of large grains of a single phase. Plutonium concentrations reported for this phase therefore represent plutonium that is incorporated into the crystal structure. This phase may form as a reaction or decomposition product from locally high plutonium concentrations in the salt and neighboring zeolite or sodalite.

\subsubsection{TEM Analysis}

A typical TEM microstructure of a hot pressed ${ }^{238} \mathrm{Pu}$ doped ceramic waste form sample is shown in Fig. 9. In this figure, there is a sodalite region about $3 \mu \mathrm{m}$ across with an average grain size of about $0.4 \mu \mathrm{m}$. Different sodalite regions are separated by a darker appearing glass phase. Actinide bearing phases are black particles mainly found in the glass area, while some small actinide bearing particles can been seen in the sodalite area as well. Several light colored round inclusions in the glass area were identified to be halite using selected area electron diffraction (SAD) and EDS. The microstructure of the sample without plutonium is similar except lacking actinide bearing particles. Some actinide bearing particles in the ${ }^{238} \mathrm{Pu}$ doped ceramic waste form samples are relatively large - with a size between 0.1 and $0.5 \mu \mathrm{m}$. A typical large actinide bearing particle is shown in Fig. 10. The selected area electron diffraction pattern of this large particle can be indexed as plutonium oxide. Some actinide bearing particles are rather small - with a size between 5 to $30 \mathrm{~nm}$. Occasionally, they form large clusters approaching a couple micrometers in size. Figure 11 is an example. As shown in this figure, SAD pattern from this cluster exhibits a ring pattern that can be indexed as plutonium oxide. 


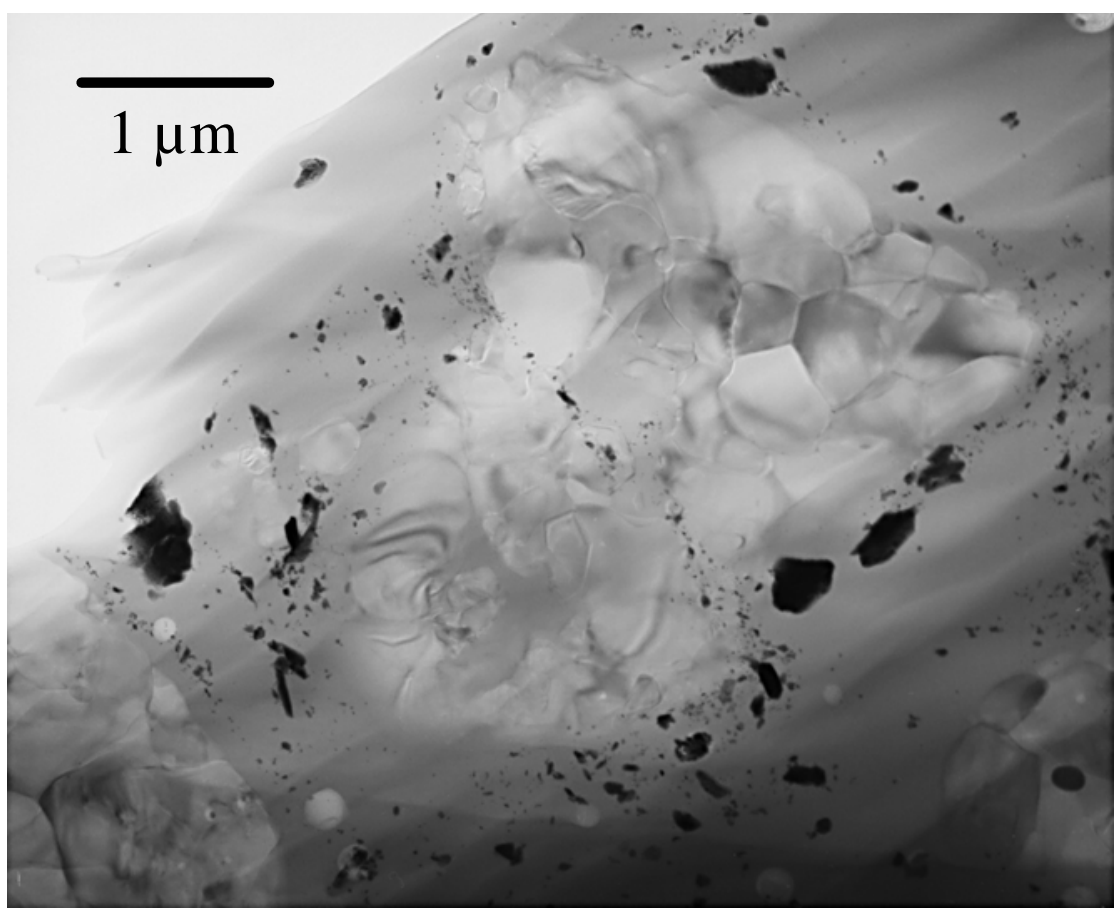

Fig. 9. A Bright Field Transmission Electron Micrograph Showing the Typical Microstructure of the ${ }^{238} \mathrm{Pu}$ Doped Ceramic Waste Form

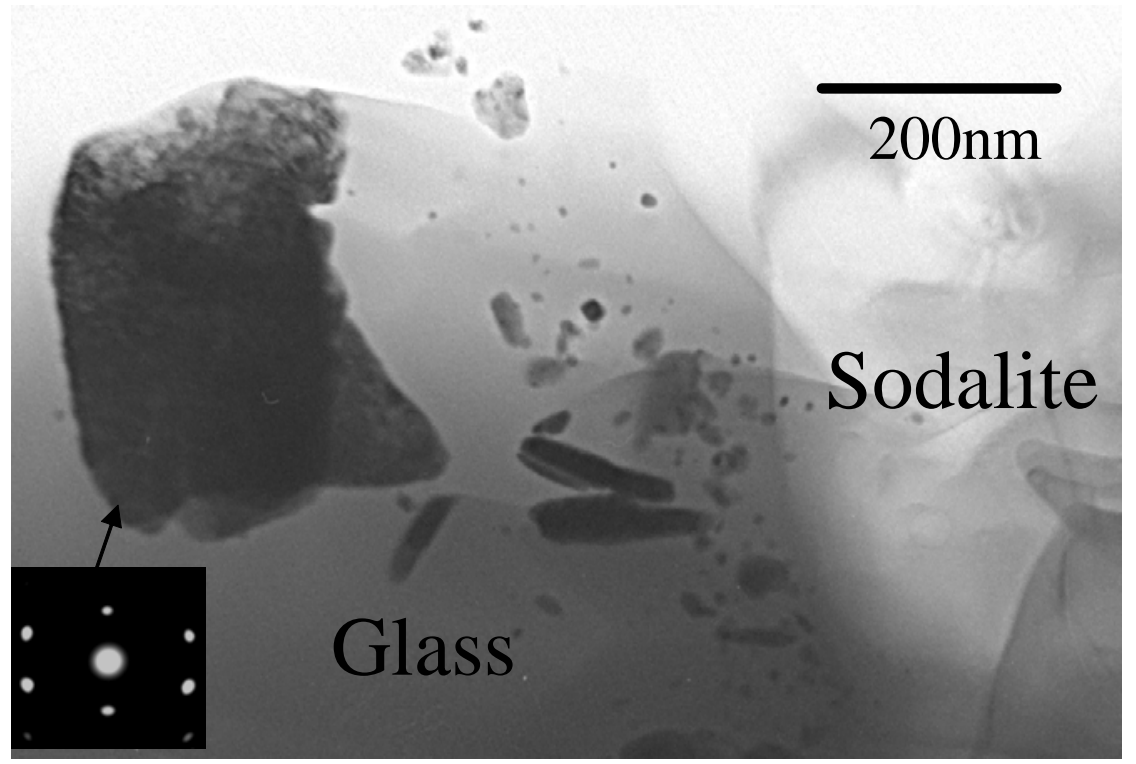

Fig. 10. A Bright Field Transmission Electron Micrograph Showing a Large Plutonium Bearing Particle in the Glass Phase 


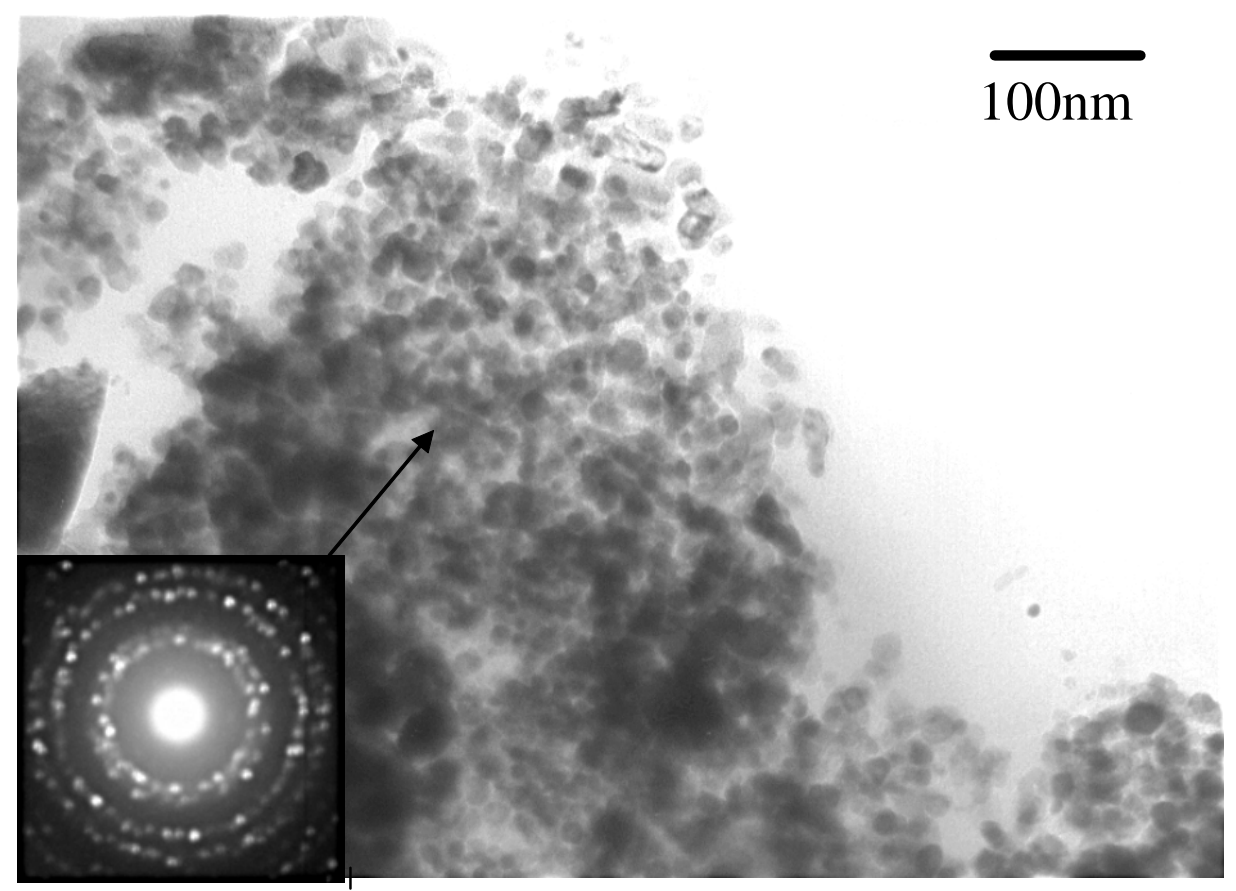

Fig. 11. A Bright Field Transmission Electron Micrograph Showing a Cluster of Plutonium Bearing Particles in the Glass Phase

\subsubsection{Radiation Damage}

There are three kinds of radiation damage that are specifically looked for in this TEM study:

1. Amorphization of sodalite and actinide bearing phases due to alpha decay. If amorphization is caused by alpha particles, which have a range of $10-20 \mu \mathrm{m}$, it should be found throughout the sample. Amorphous areas having a chemical composition similar to sodalite, or exhibiting a high plutonium concentration, should be abundant in the examined sample. If the damage is coming from recoiling particles, no wide spread amorphization of sodalite is expected due to the short range of these particles (10-20nm). Amorphized regions will be limited to actinide bearing particles and sodalite grains adjacent to them.

2. Formation of bubbles and voids. Gas bubbles can come from several possible sources, such as:

- $\quad$ Oxygen and chlorine from electrolysis [20,21],

- $\quad$ Helium from alpha particles [11],

- $\quad$ Inner gas trapped during ceramic waste form fabrication, and

- $\quad$ Argon from TEM sample preparation (i.e. ion milling). 
The origins of voids may be:

- $\quad$ Evaporation of materials under focused electron beam [9],

- $\quad$ Bubbles after releasing trapped gas,

- $\quad$ Segregation of vacancies, or

- $\quad$ Pre-existing defects after sample fabrication (less than theoretical density).

To distinguish bubbles from voids under TEM is not straightforward. No effort was given to distinguish these two defects. Segregation of bubbles or voids on grain boundaries, interfacial boundaries, or existing defects (such as preexisting bubbles and voids) can take place if diffusion is fast enough. However, as mentioned earlier, if the source of bubbles and voids is alpha radiation, the bubbles and voids should exist throughout the sample.

3. Micro-cracking along grain boundaries or interfacial boundaries. Segregation of defects such as bubbles and voids can form micro-cracks. Cracking of the ceramic waste form may also be the results of the volume change of one or more phases. Volume changes can come from (1) phase separation or crystallization of glass, (2) structural damage or amorphization of sodalite, (3) structural damage or amorphization of actinide bearing phases. Interfacial boundaries, especially around the actinide bearing phases, are the key areas to be characterized. Extensive cracking can increase the open surface area to possible corrosive media or weaken the bonding between the actinide bearing phases and the host phases (mainly glass). A higher release rate of actinides to the environment may be the outcome.

Figure 12 is a comparison of general TEM microstructure between a ceramic waste form sample without ${ }^{238} \mathrm{Pu}$ (no radiation damage) and a ${ }^{238} \mathrm{Pu}$ doped ceramic waste form sample after aging at room temperature for four years. As can be seen in Fig. 12, there is no notable difference between these two samples. Selected area electron diffraction data from the aged sample show that sodalite and plutonium bearing phases remain crystalline. It is concluded that radiation damages due to alpha decay did not cause amorphization of crystalline phases in the ${ }^{238} \mathrm{Pu}$ doped ceramic waste form up to the accumulated alpha decay events of this study.

Occasionally, in the aged ${ }^{238} \mathrm{Pu}$ doped ceramic waste form samples, bubbles and voids were found in the glass and sodalite regions as shown in Fig. 13. These features were commonly found in ceramic waste form samples without ${ }^{238} \mathrm{Pu}$. Figure 14 is an example. As mentioned earlier, the radiation damages due to alpha particles should generate bubbles and voids throughout the sample. If the kinetics is feasible, bubbles and voids could segregate along grain boundaries and interfacial boundaries. These were not observed in the ${ }^{238} \mathrm{Pu}$ doped ceramic waste form samples after aging for four years. Thus, these bubbles and voids in the ${ }^{238} \mathrm{Pu}$ doped ceramic waste form samples after aging are interpreted as pre-existing defects. However, the possibility of helium gas diffusing to these preexisting bubble and voids can not be ruled out. A significant contribution of 
helium gas to the existing defects may change their size and density. No statistically significant differences in the bubble size (20-200nm) and density were observed between the samples with and without alpha decay damages.

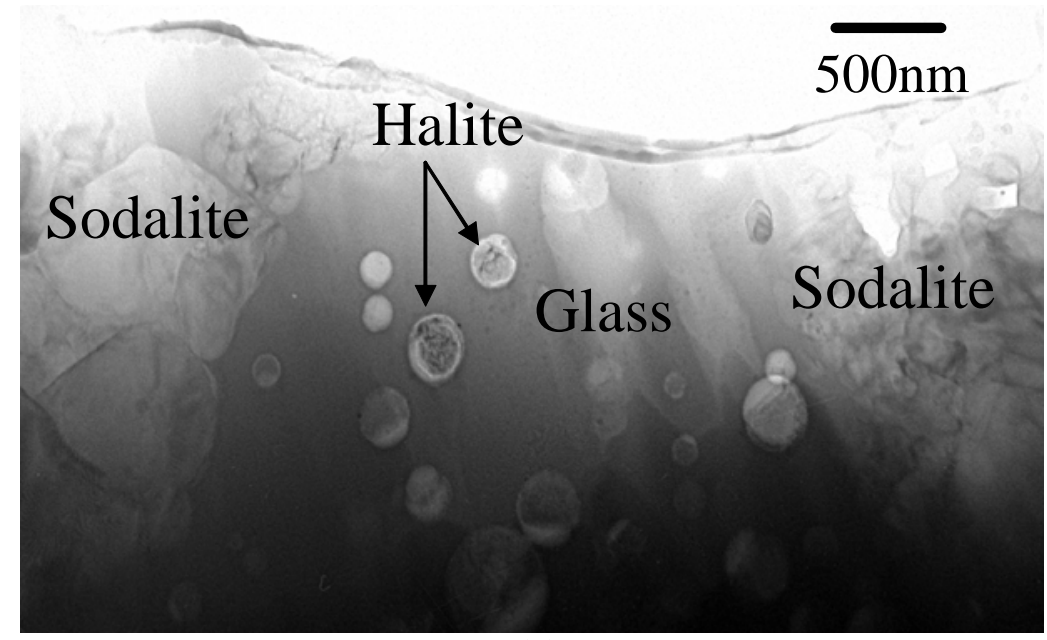

(a)

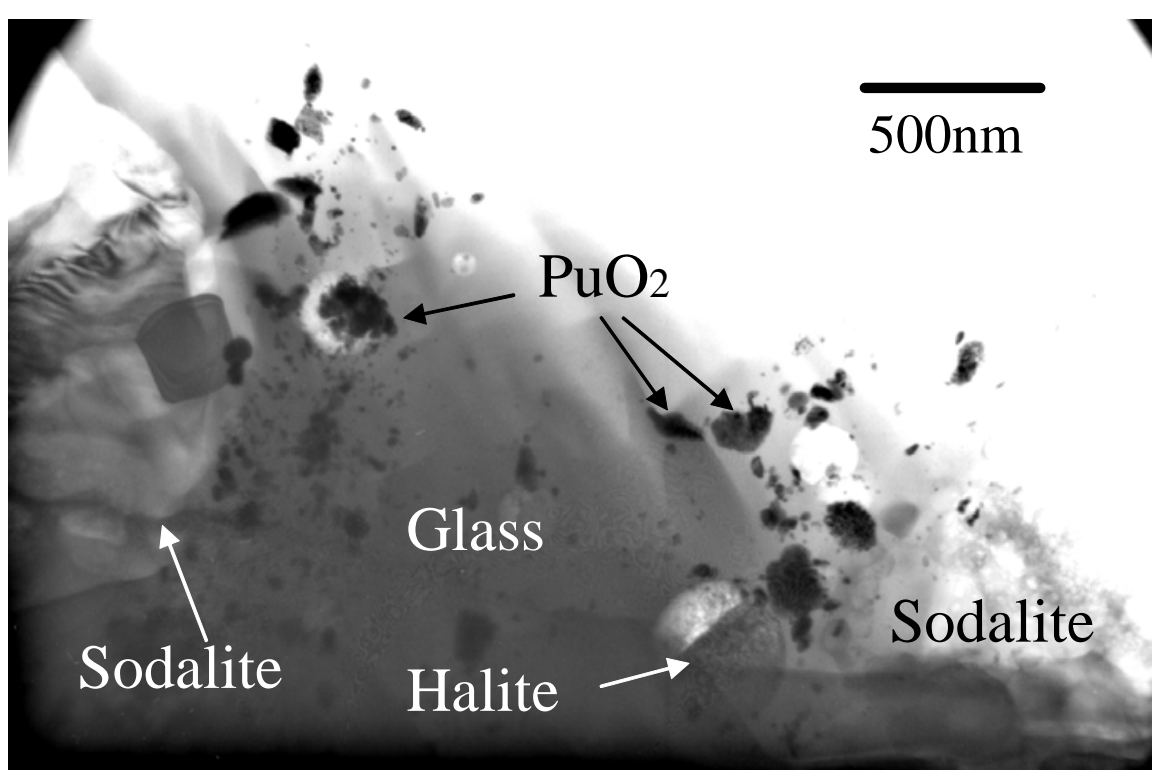

(b)

Fig. 12. Bright Field Transmission Electron Micrographs Showing the Microstructure of (a) A Ceramic Waste Form Sample Without ${ }^{238} \mathrm{Pu}$ (b) $\mathrm{A}{ }^{238} \mathrm{Pu}$ Doped Ceramic Waste Form Sample Aged For Four Years 


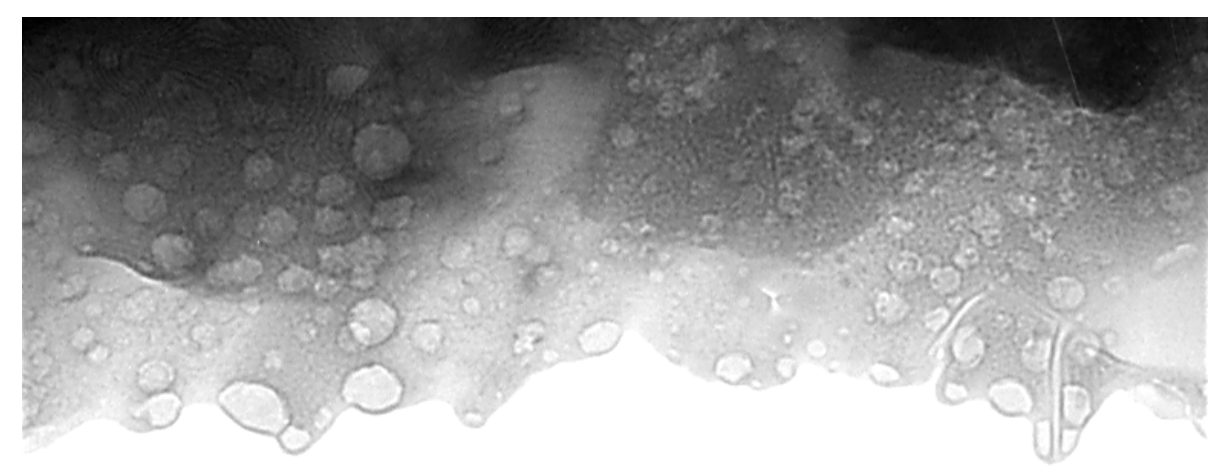

\section{$200 \mathrm{~nm}$}

Fig. 13. A Bright Field Transmission Electron Micrograph Showing Bubbles in the ${ }^{238} \mathrm{Pu}$ Doped Ceramic Waste Form Sample

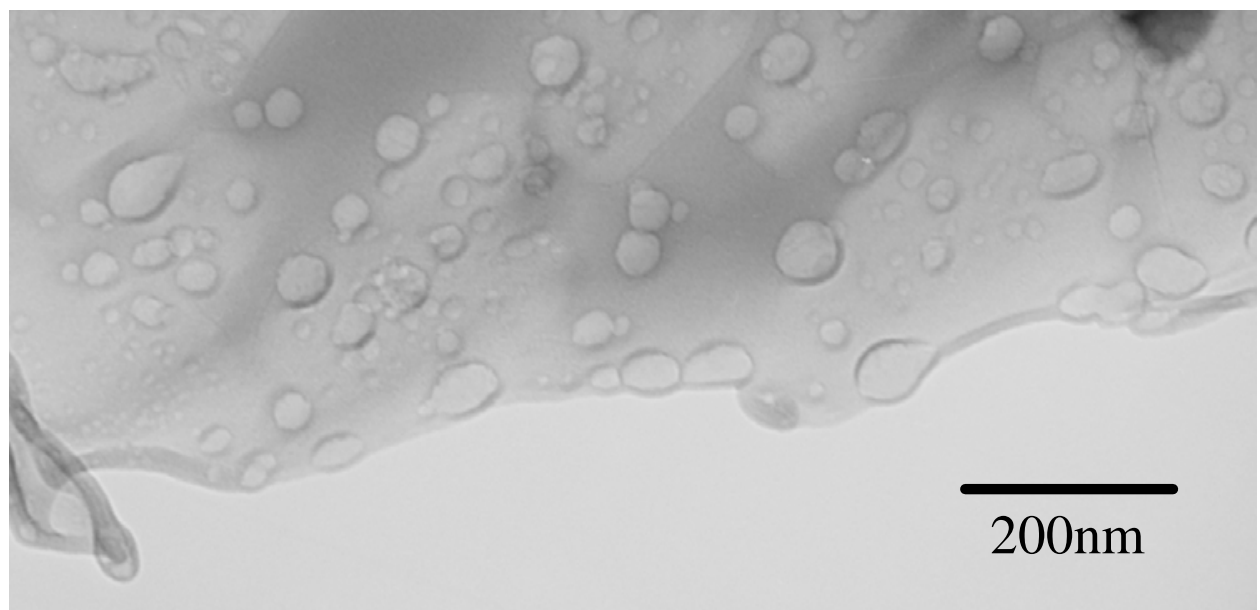

Fig. 14. A Bright Field Transmission Electron Micrograph Showing Bubbles in a Ceramic Waste Form Sample Without ${ }^{238} \mathrm{Pu}$

Higher magnification TEM bright field images reveal no microcracks on the interfaces between large actinide bearing particles and glass. An example is given in Figure 15. This indicates that the small unit cell expansion of plutonium oxide that observed by XRD in the early stage of aging did not create enough mechanical stress to degrade the bonding between the actinide bearing phases and the host phase. 


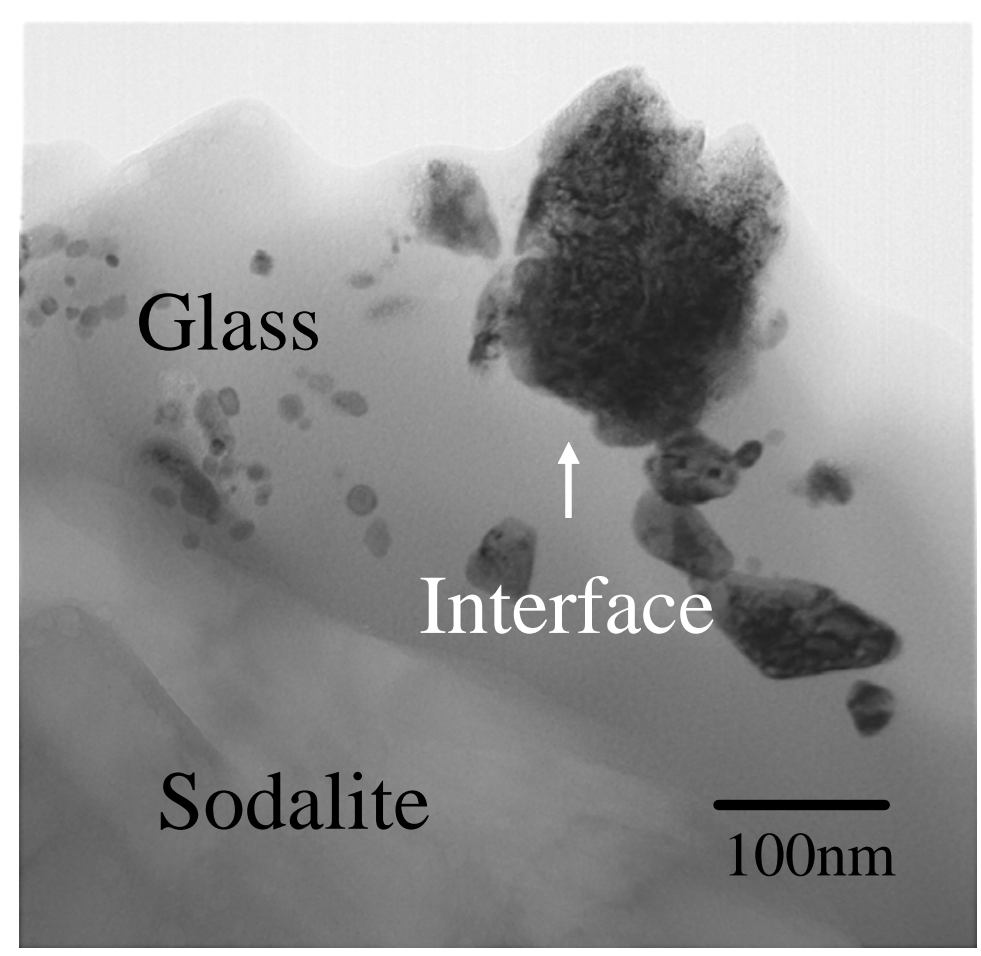

Fig. 15. A Bright Field Transmission Electron Micrograph Showing a Large Plutonium Bearing Particle in the Glass Phase (no microcracking was observed)

Just like many other zeolite group minerals, crystalline sodalite subjected to intense radiation may be amorphized. In order to study the consequence of the amorphization of sodalite on the mechanical integrity of ceramic waste forms, an in-situ amorphization experiment was conducted on a ${ }^{238} \mathrm{Pu}$ doped ceramic waste form sample aged for four years. A region containing sodalite grains, glass, and plutonium bearing particles was chosen as shown in Fig. 16. Figure 17 is a TEM micrograph of the same region after being exposed to a $200 \mathrm{keV}$ electron beam for 5 min (which corresponds to a dose of $10^{20} \mathrm{e}^{-} / \mathrm{cm}^{2}$ ). As shown in the inserted selected area electron diffraction pattern, the exposed sodalite region became amorphous. No microcracks were found inside the amorphized region or along boundaries between the exposed and un-exposed regions. These results indicate that the amorphization of sodalite should not raise mechanical integrity concerns. 


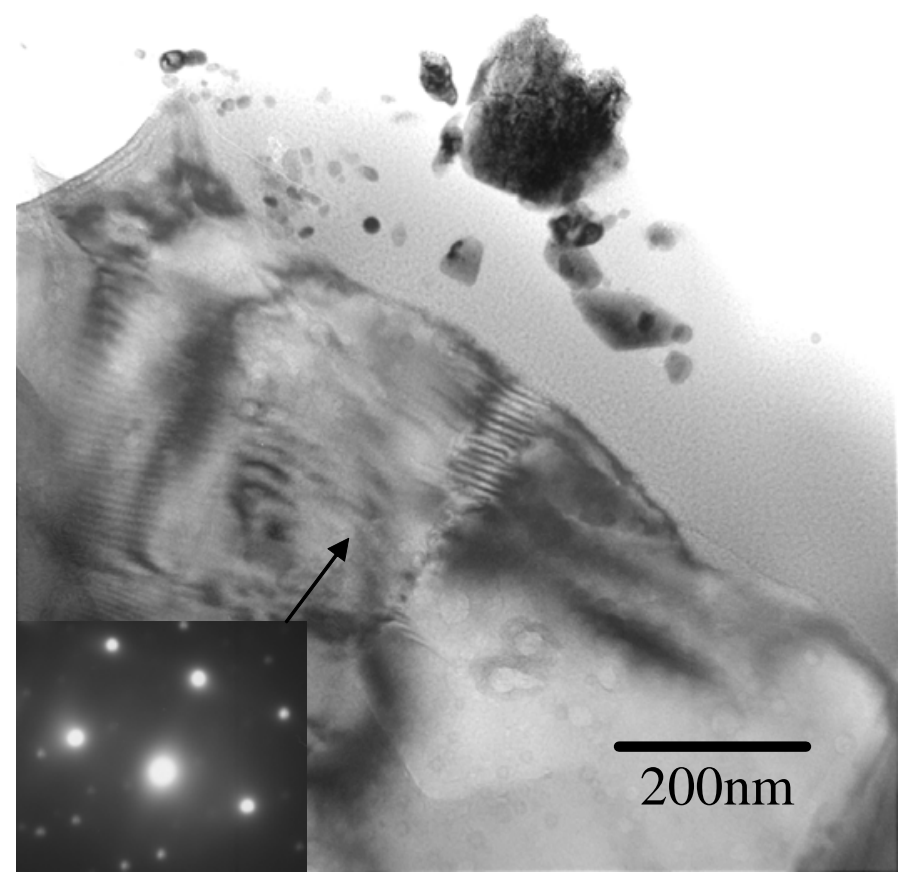

Fig. 16. A Bright Field Transmission Electron Micrograph Showing a Region Containing Sodalite Grains, Glass, and Plutonium Bearing Particles

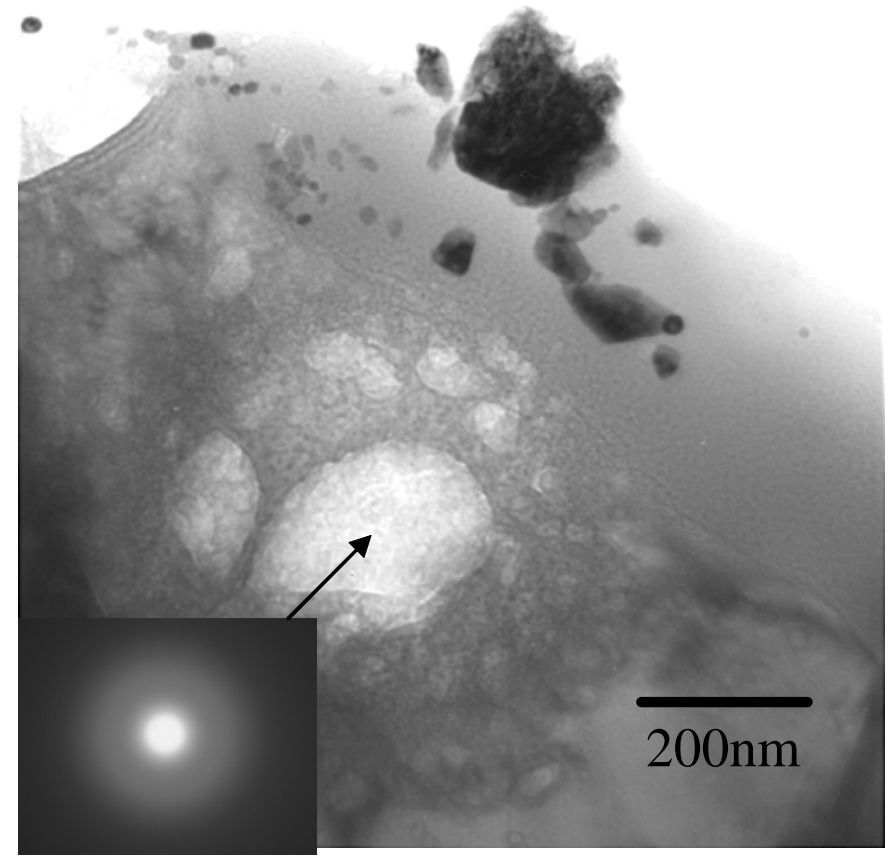

Fig. 17. A Bright Field Transmission Electron Micrograph Showing the Same Region as Fig. 16 After Exposed to an Intense Electron Beam (dose $\sim 10^{20} \mathrm{e}^{-/} / \mathrm{cm}^{2}$ ) 
Finally, in two instances, rather large particles of the high-Pu aluminosilicate phase described in the SEM section above were identified and characterized using EDS and electron diffraction patterns. Figure 18 shows a bright field micrograph with possible Pu-aluminosilicate phases visible and Fig. 19 shows an EDS spectrum from this phase (spectrum 21). In addition to plutonium and oxygen the spectrum shows strong silicon, aluminium and chlorine peaks. Using WDS in the SEM, it was also possible to identify potassium as a component of this phase (the $k$-lines of potassium overlap in EDS with the Pu $m$-lines). It was not possible to index the diffraction patterns from the high-Pu aluminosilicate phase to any oxide, chloride, oxychloride, silicide or silicate phase of plutonium, or to any rare earth oxide structure. With the help of several diffraction patterns taken from a single particle, and using goniometer measurements of the angles between the zone axes, it was however possible to devise a small body-centered tetragonal unit cell to which all of the patterns could be indexed.

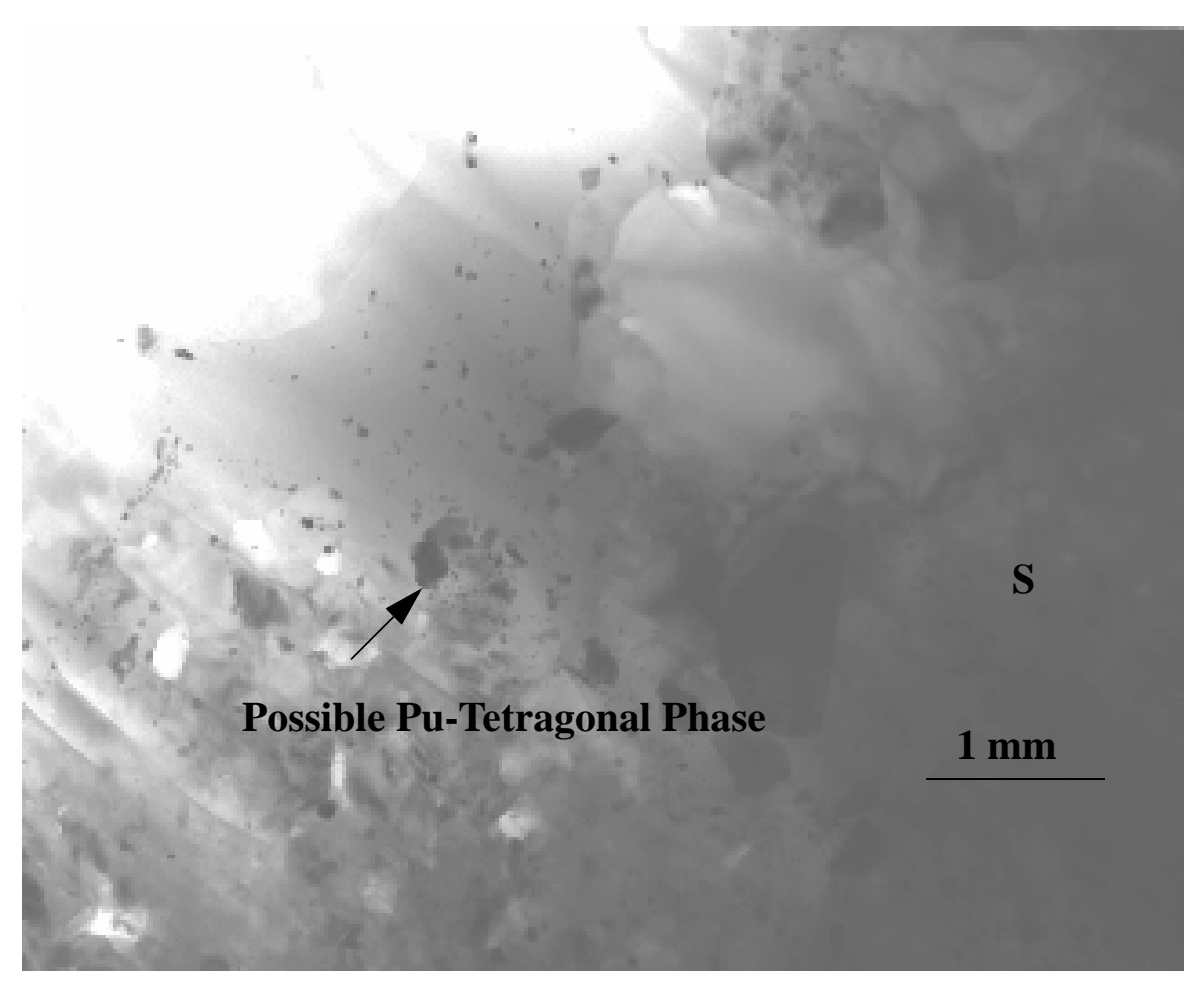

Fig. 18. TEM Micrograph with Contrast Dominated by Absorption Properties (large dark crystals are visible in contact with sodalite [S]), these may be either $\mathrm{PuO}_{2}$ or unknown tetragonal phase) 


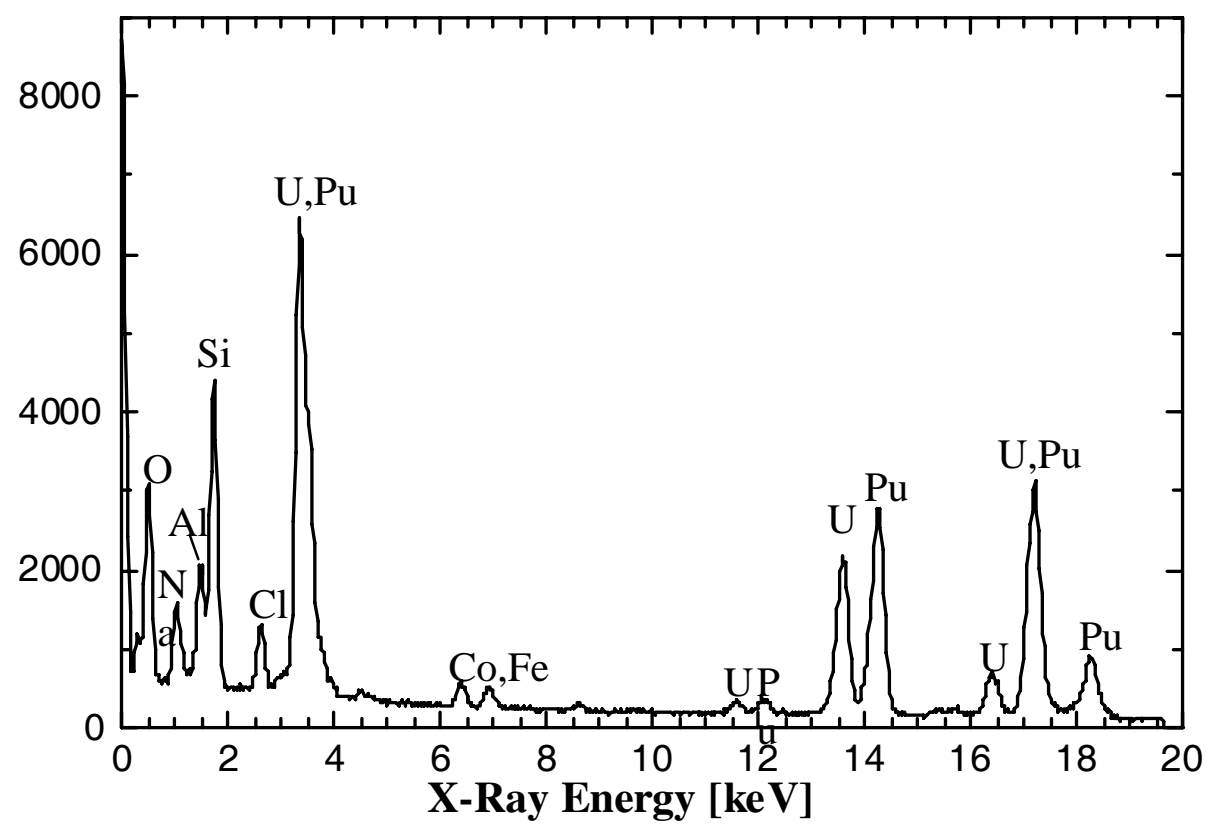

Fig. 19. EDS Spectrum from a Particle of Unidentified Tetragonal Phase

The lattice parameters so determined were $\mathrm{a}=4.1 \AA$ (with approximately $5 \%$ error due to camera length uncertainty) and c/a=1.36 \pm 0.05 . Figure 20 a-e (Nos. 808, 810, 811, 865, 868) present the diffraction patterns from which this cell was deduced. Figure 20a presents the [001] zone axis pattern of the proposed tetragonal unit cell. By tilting about the (020) reflection, the [ $\overline{1} 02]$ pattern in Fig. 20b was obtained, which has $<121>$ type reflections situated above or below the $<120>$ reciprocal lattice positions of Fig. 20a (small triangles in Fig. 20a). This indicates that the $<120>$ positions cannot be relegated to non-integer status by using a smaller unit cell. Rather, the $<120>$ reflections must be systematic extinctions, which is consistent with a body centered unit cell. Further support for this is found in the absence of intensity at the \pm (201) positions of Fig. 20b. Figures 20c-e were obtained from a second crystal of the high-Pu aluminosilicate phase. Figure 20c is again a [ 102$]$ zone axis pattern. Tilting away from this zone about the (020) reflection, a pattern consistent with [ $1 \overline{1} 01]$ was encountered, again showing systematic extinctions in agreement with a body-centered cell. Finally, tilting from [ $\overline{1} 02]$ about the (211) reflection, a $[\overline{1} 13]$ zone axis pattern is shown in Fig. 20e. Each zone axis except Fig. 20a allows independent measurement of the c/a ratio. Table 8 presents a comparison of the results of these measurements, and their errors, assuming a $2 \%$ measurement error on the relative spacings from the negatives. All are consistent with a c/a ratio between 1.31 and 1.41. 


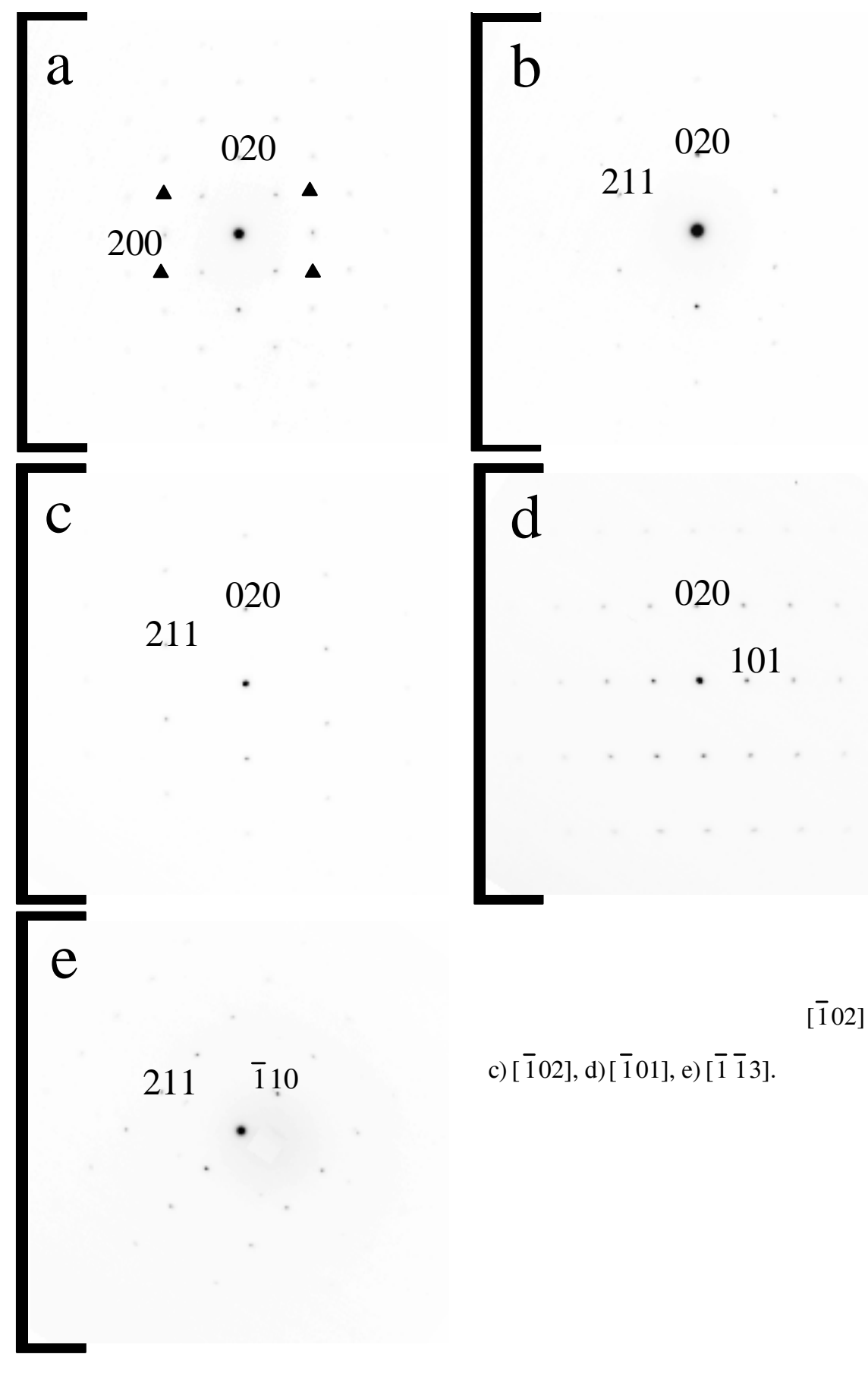

Fig. 20. Selected Area Diffraction Pattern's (SADP's) From Unknown

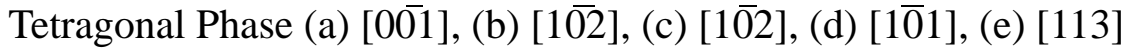


Table 8. Measurements of C/A Ratio of Unknown Phase, from SADP Patterns

\begin{tabular}{|c|c|c|c|}
\hline Figure & Zone Axis & C/A & Error \\
\hline \hline $20 \mathrm{~b}$ & {$[\overline{1} 02]$} & 1.54 & 0.29 \\
\hline $20 \mathrm{c}$ & {$[\overline{1} 01]$} & 1.38 & 0.29 \\
\hline $20 \mathrm{~d}$ & {$[\overline{1} \overline{1} 3]$} & 1.39 & 0.08 \\
\hline $20 \mathrm{e}$ & {$[\overline{1} 02]$} & 1.21 & 0.20 \\
\hline
\end{tabular}

Further corroboration of the proposed crystal lattice was obtained by measured goniometer tilts. The measured tilt angle between Fig. $20 \mathrm{a}$ and $\mathrm{b}$ was $18.4^{\circ}$, compared to $19.75^{\circ}$ for $\mathrm{c} / \mathrm{a}=1.38$. The relative angles of Fig. 20c-e are presented in Table 9. Errors in the experimental values can be significant, and are primarily due to beam-induced distortion of the sample in the course of obtaining the data, as well as to goniometer inaccuracy and slight beam tilts used to center the patterns. Overall, the agreement is excellent. Literature searches to obtain a match to this lattice are continuing. Two phases which bear a superficial resemblance are plutonium orthosilicate $\mathrm{PuSiO}_{4}$ and plutonium oxide chloride PuOCl. The former is body centered tetragonal, but with $\mathrm{a}=6.9 \AA$ and $\mathrm{c}=6.2$ [22]. The latter is tetragonal with $\mathrm{a}=4.01$ and $\mathrm{c}=6.79$ ( $\mathrm{c} / \mathrm{a}=1.69$ ), but has $\mathrm{a}$ primitive lattice, space group P4/nmm [23]. For this symmetry, there are additional reflections in both the $[\overline{1} 02]$ and $[\overline{1} 01]$ zone axes. Several other potential candidates for the structure are found in the Pearson groups tI4 and tI6 [24], but further experimental corroboration is required for a positive identification. An image of a grain of this phase is shown in Fig. 21.

Table 9. Relative Angles, In Degrees, For The Zone Axes in

Fig. 20c-e (values are given as pairs, experimental calculated)

\begin{tabular}{|c|c|c|c|}
\hline & Fig. 20c & Fig. 20d & Fig. 20e \\
\hline \hline Fig. 20c & 0 & $16.1,15.9$ & $14.6,14.5$ \\
\hline Fig. 20d & --- & 0 & $25.6,26.6$ \\
\hline Fig. 20e & --- & --- & 0 \\
\hline
\end{tabular}




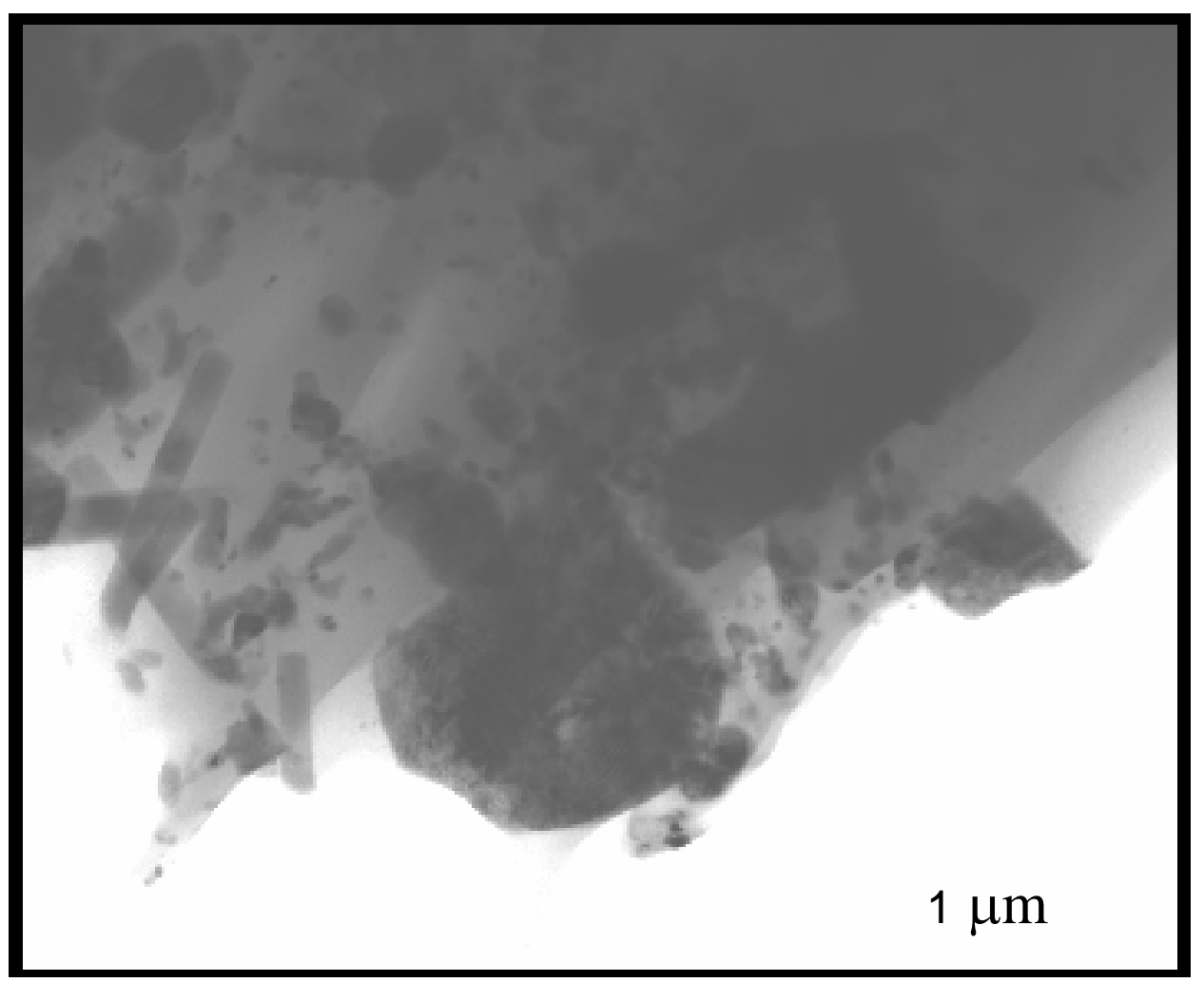

Fig. 21. Bright Field Image (BFI) of a Particle of the Unknown Tetragonal Phase (T)

In addition to the four phases described here, at least two additional phases exist in this sample, as indicated by SEM. These are an iron-plutonium phase, as well as a rare-earth containing phase with a minor plutonium component. Because these phases are minor components of the HUP pellet, and are relatively sparsely distributed, no examples were found in the thin regions of the TEM sample.

Summarizing the major findings from the microscopy analysis of the ${ }^{238} \mathrm{Pu} C W F$ material after four years of cumulative alpha-decay damage, the material is very similar to the actual CWF and no changes to the microstructure were observed after exposure to alpha damage at the micronsize range. There is no indication of amorphization of the sodalite or actinide bearing phases after four years of self-damaging study. In some areas of the ${ }^{238} \mathrm{Pu}$ doped ceramic waste form samples after aging, bubbles and voids were found. Bubbles and voids with similar size and density were also found in ceramic waste form samples without actinide. These bubbles and voids are interpreted as pre-existing defects. However, some contribution to these bubbles and voids from helium gas can not be ruled out. Finally, no microcracks were found in the actinide bearing ceramic waste form samples. Furthermore, when exposed to an intensive electron beam, sodalite became amorphous; however, no microcracking was observed on the interface between the amorphized sodalite and surrounding areas. 


\subsection{Chemical Durability}

Chemical durability of the ${ }^{238} \mathrm{Pu}$ CWF after exposure to alpha decay was determined using the ASTM leaching method known as the product consistency test or PCT. The chemical durability of a material as applied by the ASTM PCT method is defined as the resistance of the material to release its constituents to the test solution (such as pure water, ground water, brine solution, etc.) under specific test conditions [15]. This test was developed to evaluate the chemical durability of crushed nuclear waste glass. The standardized test can also be applied to study the corrosion behavior of the test material and has been applied to the determination of the CWF chemical durability [25]. The chemical durability is determined by measuring the concentrations of chemical species in the test solution that had been released from the test material. The data from the test are then used to calculate the normalized elemental mass loss of species from the test material. This test was developed to evaluate the consistency of a glass material during production, but can be applied to monitor any changes in durability of the CWF with cumulated alpha-decay damage. The test was performed on three occasions during the 4 year test period: shortly after the ${ }^{238} \mathrm{Pu}$ CWF HUP pellets had been produced, at approximately the two-year period, and at the end of the test period. As mentioned previously, 11 HUP pellets produced from batch 1 material were ground and sieved to a specific particle size, as the starting material for all three PCTs. The PCT results from all three tests are shown in Table 10. Table 10 also shows the measurement uncertainty at the $2 \mathrm{~s}$ ( $2 \mathrm{x}$ the standard deviation) or $95 \%$ confidence interval. Table 11 compares the elemental mass loss for selected elements from the ${ }^{238} \mathrm{Pu}$ CWF material to the non-plutonium reference CWF. Maintaining a constant surface area to leachant volume allows for comparison of normalized elemental release between different sample types and samples of different particle size.

Table 10. Normalized Elemental Release in $\mathrm{g} / \mathrm{m}^{2}$ for a 7-day PCT (values shown for selected species released from the ground ${ }^{238} \mathrm{Pu}$ CWF material are the averages from triplicate tests, also shown are the measurement uncertainties at two times the standard deviation, or $95 \%$ confidence interval)

\begin{tabular}{|c|c|c|c|c|}
\hline \multicolumn{2}{|l|}{ Elements } & $\begin{array}{l}\text { Normalized Release } \\
\text { for PCT after } 5.0^{*} 10^{16} \\
\text { a decays/g } \\
(\mathrm{t}=0.2 \mathrm{yrs})\end{array}$ & $\begin{array}{l}\text { Normalized Release } \\
\text { for PCT after } \\
\begin{array}{r}5.0^{*} 10^{17} \text { a decays } / \mathrm{g}(\mathrm{t} \\
=2 \mathrm{yrs})\end{array}\end{array}$ & $\begin{array}{l}\text { Normalized Release } \\
\text { for PCT after } \\
\begin{array}{r}1.0^{*} 10^{18} \text { a decays/g (t } \\
=4 \text { yrs })\end{array}\end{array}$ \\
\hline \multirow{2}{*}{$\begin{array}{l}\text { Major } \\
\text { elements in } \\
\text { sodalite/glass }\end{array}$} & Si & Not measured & $\overline{0.038 \pm 0.008}$ & 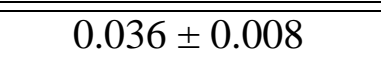 \\
\hline & $\mathrm{Al}$ & $0.035 \pm 0.008$ & $0.034 \pm 0.006$ & $0.026 \pm 0.006$ \\
\hline \multirow[t]{4}{*}{ Salt } & $\mathrm{Na}$ & Not measured & $0.23 \pm 0.02$ & $0.74 \pm 0.14$ \\
\hline & $\mathrm{Cl}$ & $0.38 \pm 0.08$ & $0.74 \pm 0.14$ & $1.17 \pm 0.24$ \\
\hline & $\mathrm{Li}$ & $0.44 \pm 0.08$ & $0.48 \pm 0.06$ & $0.58 \pm 0.12$ \\
\hline & I & Not measured & $0.21 \pm 0.10$ & $1.78 \pm 0.36$ \\
\hline \multirow{2}{*}{$\begin{array}{l}\text { Potential } \\
\text { glass markers }\end{array}$} & K & $0.09 \pm 0.14$ & $0.13 \pm 0.04$ & $0.14 \pm 0.02$ \\
\hline & B & $0.23 \pm 0.04$ & $0.35 \pm 0.08$ & $0.32 \pm 0.06$ \\
\hline
\end{tabular}


Table 10. (Contd.)

\begin{tabular}{|l|l|c|c|c|}
\hline \multicolumn{2}{|c|}{ Elements } & $\begin{array}{c}\text { Normalized Release } \\
\text { for PCT after } 5.0^{*} 10^{16} \\
\text { a decays/g } \\
(\mathrm{t}=0.2 \mathrm{yrs})\end{array}$ & $\begin{array}{c}\text { Normalized Release } \\
\text { for PCT after } \\
5.0^{*} 10^{17} \mathrm{a} \text { decays/g } \\
=2 \mathrm{yrs})\end{array}$ & $\begin{array}{c}\text { Normalized Release } \\
\text { for PCT after } \\
1.0^{*} 10^{18} \mathrm{a} \text { decays/g }(\mathrm{t} \\
=4 \mathrm{yrs})\end{array}$ \\
\hline \hline Actinides & $\mathrm{Pu}$ & $0.0007 \pm 0.0004$ & $0.0020 \pm 0.0004$ & $0.0048 \pm 0.0010$ \\
\hline Rare earths & $\mathrm{Nd}$ & $0.0012 \pm 0.0002$ & $0.0048 \pm 0.0010$ & $0.024 \pm 0.004$ \\
\hline Other & $\mathrm{Cs}$ & $0.15 \pm 0.04$ & $0.35 \pm 0.08$ & $0.21 \pm 0.04$ \\
\hline
\end{tabular}

Table 11. Comparison of Normalized Elemental Release $\left(\mathrm{g} / \mathrm{m}^{2}\right)$ from the Reference CWF Material Containing No Pu to the ${ }^{238} \mathrm{Pu}$ CWF Material (values shown for selected species released during the PCT are the averages from triplicate measurements from the ${ }^{238} \mathrm{Pu}$ CWF tests and from long term testing of the reference CWF, also shown are the measurement uncertainties at two times the standard deviation, or 95\% confidence interval)

\begin{tabular}{|c|c|c|c|c|}
\hline \multicolumn{2}{|l|}{ Elements } & $\begin{array}{c}\text { Normalized Release } \\
\text { for Reference CWF } \\
\text { PCT Containing No } \\
\text { Pu }\end{array}$ & $\begin{array}{l}\text { Normalized Release } \\
\text { for PCT after } \\
\begin{array}{c}5.0^{*} 10^{16} \mathrm{a} \text { decays } / \mathrm{g}(\mathrm{t} \\
=0.2 \mathrm{yrs})\end{array}\end{array}$ & $\begin{array}{l}\text { Normalized Release } \\
\text { for PCT after } \\
\begin{array}{c}1.0^{*} 10^{18} \text { a decays } / \mathrm{g}(\mathrm{t} \\
=4 \mathrm{yrs})\end{array}\end{array}$ \\
\hline \multirow{2}{*}{$\begin{array}{l}\text { Major } \\
\text { elements in } \\
\text { sodalite/glass }\end{array}$} & $\mathrm{Si}$ & $0.078 \pm 0.011$ & Not measured & $0.036 \pm 0.008$ \\
\hline & $\mathrm{Al}$ & $0.086 \pm 0.012$ & $0.035 \pm 0.008$ & $0.026 \pm 0.006$ \\
\hline \multirow{4}{*}{ Salt } & $\mathrm{Na}$ & $0.11 \pm 0.02$ & Not measured & $0.74 \pm 0.14$ \\
\hline & $\mathrm{Cl}$ & $0.62 \pm 0.31$ & $0.38 \pm 0.08$ & $1.17 \pm 0.24$ \\
\hline & $\mathrm{Li}$ & $0.37 \pm 0.06$ & $0.44 \pm 0.08$ & $0.58 \pm 0.12$ \\
\hline & I & $0.77 \pm 0.67$ & Not measured & $1.78 \pm 0.36$ \\
\hline \multirow{2}{*}{$\begin{array}{l}\text { Potential glass } \\
\text { markers }\end{array}$} & $\mathrm{K}$ & $0.065 \pm 0.024$ & $0.09 \pm 0.14$ & $0.14 \pm 0.02$ \\
\hline & B & $0.21 \pm 0.12$ & $0.23 \pm 0.04$ & $0.32 \pm 0.06$ \\
\hline Actinides & $\mathrm{Pu}$ & & $0.0007 \pm 0.0004$ & $0.0048 \pm 0.0010$ \\
\hline Rare earths & $\mathrm{Nd}$ & $0.0037 \pm 0.0046$ & $0.0012 \pm 0.0002$ & $0.024 \pm 0.004$ \\
\hline Other & Cs & $0.048 \pm 0.023$ & $0.15 \pm 0.04$ & $0.21 \pm 0.04$ \\
\hline
\end{tabular}

The overall elemental release behavior varies little between the first PCT and the final test after a cumulated dose of $1.03 \times 10^{18}$ alpha decays/g for the elements measured, with the exception of $\mathrm{Na}, \mathrm{Cl}, \mathrm{I}$ and Pu. These elements show a statistically significant tread toward higher release rates 
with cumulated alpha-decay dose. Statistically significant defined here is greater than the 95\% confidence interval and for a continuous trend of either increasing or decreasing elemental release with cumulated dose. The major elements ( $\mathrm{Si}, \mathrm{Al}$ and $\mathrm{B}$ ) from the sodalite and glass matrices show no significant increase in release. This would indicate that the chemical durability of the waste form is maintaining its integrity with cumulated alpha-decay damage.

The increasing release of $\mathrm{Na}, \mathrm{Cl}, \mathrm{I}$ and $\mathrm{Pu}$ with cumulated dose is an interesting trend. The higher release rates of $\mathrm{Na}$ and $\mathrm{Cl}$ would indicate that the halite phase found primarily in the glass matrix, is being increasingly exposed with increased alpha damage. Evidence from the analysis of water rinse of the CWF powder performed prior to the PCT indicates that iodine is associated primarily in the halite phase and agrees with the $\mathrm{Na}$ and $\mathrm{Cl}$ release from the halite. The higher release of $\mathrm{Na}, \mathrm{Cl}$ and I from the halite phase would not be inconsistent with where most of the energy released during alpha decay is deposited. Most of the plutonium in the CWF resides as oxide inclusions within the glass displaced from the sodalite regions. Cesium is also found primarily in the glass phase. Because of the general distribution of plutonium, the two phases that will have the most energy deposited during alpha decay will be the plutonium oxide and the glass. The majority of the damage is then greatly localized in the $\mathrm{PuO}_{2}$ and the glass interface region adjacent to the $\mathrm{PuO}_{2}$ phase since the recoil nucleus, after an alpha decay, imparts the greatest damage, but only travels a short distance (tens of nanometers) from its origin. Higher numbers of dislocations in the $\mathrm{PuO}_{2}$ and glass may lower the durability of those areas so that more $\mathrm{Pu}$ and halite, also located in the glass regions, is released during the product consistency test. An increase in the release of $\mathrm{Si}$ and $\mathrm{Al}$ because of radiation damage in the glass is not expected, however, since release of these elements is dominated by the more abundant sodalite phase.

While this may be a plausible explanation for increased $\mathrm{Na}, \mathrm{Cl}$ and $\mathrm{Pu}$ release with increasing alpha decay damage, one would also expect higher release of B and Cs (Cs is also found primarily in the glass phase), but this is not the case. Boron and Cs show no clear trend to greater release with increasing alpha decay damage. This seeming contradiction in observations can be explained by the possibility of radiation induced migration of $\mathrm{Na}$ and $\mathrm{Cl}$ through the glass to damaged regions of the glass adjacent to the $\mathrm{PuO}_{2}$ phase [26]. This would expose more Na and $\mathrm{Cl}$, if migration occurred, to the leachate during the PCT. This possibility is purely speculation; however, as there is no experimental evidence, either by microscopy or differential thermal analysis (DTA) (the DTA analysis was not performed due to facility constraints as mentioned earlier in this report) that can measure stored system energy increase due to cumulated alpha decay.

A third possibility exists to explain the increase of $\mathrm{Na}$ and $\mathrm{Cl}$ release, and this involves mechanical stress to the Pu-CWF system as an artifact of sample preparation for the PCT. Before the PCT, the sample was ground to a powder and this grinding can mechanically weaken the grain boundaries between different phases of the waste form. The mechanical failure may or may not be a result of alpha decay damage, but if mechanical failure occurs between the sodalite and glass phase boundaries, where incidentally the halite occlusions are most readily located, then, upon exposure to water during the PCT, the halite will rapidly dissolve into the leachate. Again, this is only a possible explanation for the increase in $\mathrm{Na}, \mathrm{Cl}$ and I release, in that, at this time, there is no experimental evidence to confirm the possibilities mentioned. 
Likewise, an increase in Pu release with increasing alpha decay damage is not unexpected based on the discussion above regarding where the majority of alpha decay damage occurs, that is the $\mathrm{PuO}_{2}$ region. Even so, the normalized mass loss of $\mathrm{Pu}$ is still extremely low after the four years of alpha decay damage.

\subsection{Density}

Density measurements are performed periodically on the ${ }^{238} \mathrm{Pu}$-loaded CWF using an immersion technique. Decrease in density can be attributed to macroscopic swelling due to radiation damage to the bulk material [27].

The density of the ${ }^{238} \mathrm{Pu}$-loaded CWF sample has remained unchanged, with respect to the measurement uncertainty, during the testing period to date as shown in Table 12. A decrease in density of the sample provides the most direct evidence of macroscopic volume expansion due to alpha-decay damage, yet as mentioned none has been observed at the dose level of $1.4 \times 10^{18}$ alpha-decays/gram of material. The density of the ${ }^{238} \mathrm{Pu}$-loaded CWF, as determined by immersion in water, is $2.426 \pm 0.006 \mathrm{~g} / \mathrm{cm}^{3}$. This density compares to an average density of $2.35 \pm 0.02 \mathrm{~g} / \mathrm{cm}^{3}$ for non-Pu reference CWF material. The higher density of the ${ }^{238} \mathrm{Pu}$-loaded $\mathrm{CWF}$ is attributed to the high Pu loading in the sample.

Table 12. Measured Density $\left(\mathrm{g} / \mathrm{cm}^{3}\right)$ of ${ }^{238} \mathrm{Pu}$ CWF HUP Pellet CL034 with Increasing Alpha-Decay Damage (also shown are the measured densities of a non-Pu CWF HUP pellet and aluminum standard sample)

\begin{tabular}{|c|c|c|c|}
\hline $\begin{array}{c}\text { Dose } \\
\text { (Alpha-decay/gram) }\end{array}$ & $\begin{array}{c}\text { Pu-238 HUP Pellet } \\
\text { CL034 Density }\end{array}$ & $\begin{array}{c}\text { Non-Pu HUP Pellet } \\
\text { 36 Density }\end{array}$ & $\begin{array}{c}\text { Aluminum Standard } \\
\text { Density }\end{array}$ \\
\hline \hline $3.56 \mathrm{E} 16$ & 2.424 & & 2.690 \\
\hline $8.52 \mathrm{E} 16$ & 2.417 & & 2.700 \\
\hline $1.68 \mathrm{E} 17$ & 2.419 & & 2.694 \\
\hline $2.67 \mathrm{E} 17$ & 2.420 & & 2.692 \\
\hline $3.24 \mathrm{E} 17$ & 2.425 & $2.342 \pm 0.004$ & 2.693 \\
\hline $5.43 \mathrm{E} 17$ & 2.425 & 2.339 & 2.699 \\
\hline $6.21 \mathrm{E} 17$ & 2.426 & 2.346 & 2.697 \\
\hline $6.75 \mathrm{E} 17$ & 2.420 & 2.346 & 2.694 \\
\hline $7.66 \mathrm{E} 17$ & 2.434 & 2.334 & 2.699 \\
\hline $8.36 \mathrm{E} 17$ & 2.426 & 2.340 & 2.696 \\
\hline $8.89 \mathrm{E} 17$ & 2.434 & 2.341 & 2.701 \\
\hline $9.72 \mathrm{E} 17$ & 2.434 & 2.341 & 2.708 \\
\hline $1.05 \mathrm{E} 18$ & 2.430 & 2.339 & 2.704 \\
\hline Average \pm Std. Dev. & $2.426 \pm 0.006 \mathrm{~g} / \mathrm{cm}^{3}$ & $2.342 \pm 0.004 \mathrm{~g} / \mathrm{cm}^{3}$ & $2.698 \pm 0.005 \mathrm{~g} / \mathrm{cm}^{3}$ \\
\hline
\end{tabular}




\subsection{X-ray Analysis}

X-ray diffraction patterns from ${ }^{238} \mathrm{Pu}$ CWF HUP pellet CL031 have been acquired periodically for four years. These measurements were performed to observe any changes to the phase composition and individual phase lattice parameters with increasing alpha-decay damage to the material. XRD analyses were also performed on the salt and zeolite starting materials prior to HUP production. These patterns are shown on the overlay plot in Fig. 22. In Fig. 22, the bottom pattern has the three main phases of $\mathrm{LiCl}$ and $\mathrm{KCl}$ from the eutectic salt and the $\mathrm{K}_{2} \mathrm{PuCl}_{6}$ phase (referred to as $\mathrm{PuCl}_{3}$ ). Plutonium or uranium observed in the eutectic salt assumes the $\mathrm{K}_{2} \mathrm{AcCl}_{6}$ phase in the solid state, where Ac is the actinide present. The middle pattern in Fig. 22 is the salt occluded zeolite material. The middle pattern shows the typical zeolite pattern and a second phase (indicated by the asterisks) of $\mathrm{PuO}_{2}$. When the eutectic salt containing $\mathrm{PuCl}_{3}$ is contacted with zeolite, even very dry zeolite used to produce the CWF, residual $\mathrm{H}_{2} \mathrm{O}$ in the zeolite structure reacts strongly with $\mathrm{Pu}$ to form $\mathrm{PuO}_{2}$. This phenomenon has been observed in past studies on the behavior of the CWF [28]. The top pattern in Fig. 22 shows XRD pattern of the CWF material. $\mathrm{XRD}$ analysis of the final HUP pellet product is comprised of the glass amorphous phase and four crystalline phases: sodalite, $\mathrm{PuO}_{2}$, nepheline and halite. The phases identified by XRD analysis of the HUPed CWF compares very well with other CWF material, except for the greater quantity of $\mathrm{PuO}_{2}$ found in the $\mathrm{Pu}-\mathrm{CWF} \mathrm{HUP}$ pellets. The plutonium containing silicate and aluminosilicate phases observed by TEM and described in the TEM section above are not observed by XRD due to the low relative amounts of these phases present in the HUP material. Plutonium observed by XRD corresponds to the cubic (fluorite structure) $\mathrm{PuO}_{2}$ phase (ICDD card number 41-1170 [29]) 


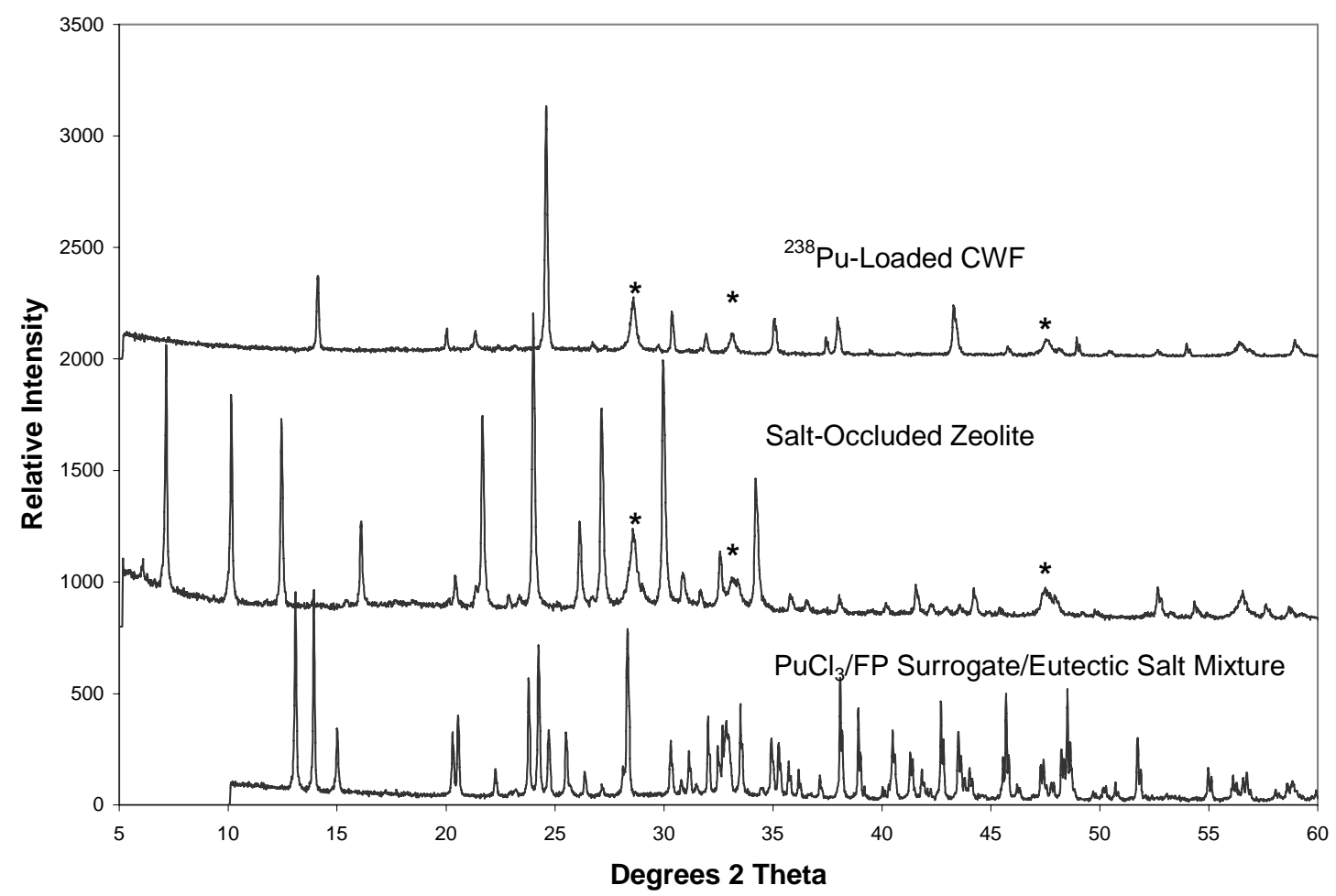

Fig. 22. XRD Patterns of HUP Starting Materials and Final CWF Product (the lower pattern shows the $\mathrm{LiCl} / \mathrm{KCl}$ eutectic with the $\mathrm{K}_{2} \mathrm{PuCl}_{6}$ phase, the middle pattern shows the zeolite and $\mathrm{PuO}_{2}$ phases and the top pattern show the sodalite, $\mathrm{PuO}_{2}$, nepheline and halite phases, the asterisk mark the $\mathrm{PuO}_{2}$ phase that forms upon salt contacting with the zeolite)

The weight percent composition of the four crystalline phases comprising HUP pellet CL031 have been determined and is shown in Table 13. The crystalline phase composition of ${ }^{238} \mathrm{Pu}$-loaded HUP sample CL031 compares well with the reference (non-Pu loaded) CWF. The amorphous content of the sample was measured to be $22 \%$ and corresponds to the target quantity of added glass binder of $25 \mathrm{wt} \%$ within experimental uncertainty.

Table 13. Phase Composition of ${ }^{238} \mathrm{Pu}$-loaded HUP Pellet CL031 in Weight Percent ( \pm absolute measurement uncertainty) As Determined by XRD (the standard reference material [SRM] $\mathrm{LaB}_{6}$ was added to the sample as an internal standard for refinement purposes)

\begin{tabular}{|l|c|c|c|c|c|c|}
\hline $\begin{array}{c}\text { Major } \\
\text { Crystalline } \\
\text { Phases }\end{array}$ & $\begin{array}{c}\text { Sodalite } \\
\mathrm{Na}_{8} \mathrm{Al}_{6} \mathrm{Si}_{6} \mathrm{O}_{24} \mathrm{Cl}_{2}\end{array}$ & $\mathrm{PuO}_{2}$ & $\begin{array}{c}\text { Nepheline } \\
\mathrm{NaAlSiO}_{4}\end{array}$ & $\begin{array}{c}\text { Halite } \\
\mathrm{NaCl}\end{array}$ & $\begin{array}{c}\text { Amorphous } \\
\text { Phase }\end{array}$ & $\begin{array}{c}\mathrm{LaB}_{6} \\
\mathrm{SRM} \\
660\end{array}$ \\
\hline $\begin{array}{l}\text { Weight percent } \\
\text { of crystalline } \\
\text { phases in CWF }\end{array}$ & $68 \pm 8$ & $3 \pm 0.6$ & $1 \pm 0.2$ & $1 \pm 0.2$ & $22 \pm 6$ & 2 \\
\hline
\end{tabular}


The most notable change to the ${ }^{238} \mathrm{Pu}$ CWF material analyzed by XRD is the increase in the unit cell volume of the $\mathrm{PuO}_{2}$ phase and a slight increase in the unit cell volume of the sodalite phase. There is no indication of a change to the phase composition of the ${ }^{238} \mathrm{Pu}$-loaded sample. Figure 23 shows the $\mathrm{PuO}_{2}$ and sodalite unit-cell volume increase with increasing alpha-decay dose, as determined by Rietveld pattern refinement using GSAS software. The SRM $\mathrm{LaB}_{6}$ was added as an internal standard to the XRD sample and was used to estimate the overall measurement uncertainty when calculating the unit-cell volume of each phase in the ${ }^{238} \mathrm{Pu}$-loaded sample. This was accomplished by first constructing an instrument parameter file using the $\mathrm{LaB}_{6} \mathrm{SRM}$ as a calibration standard for the refinement software. Then for each consecutive XRD measurement, the $\mathrm{SRM} \mathrm{LaB}_{6}$ lattice parameter was again determined using the GSAS refinement routine. The $\mathrm{LaB}_{6}$ unit-cell volume (calculated from the lattice parameter) found for each XRD measurement was then averaged and the standard deviation of the unit-cell volume determined. The standard deviation of the averaged $\mathrm{LaB}_{6}$ unit-cell volume is used as the overall measurement uncertainty associated with the $\mathrm{PuO}_{2}$ and sodalite unit-cell volumes. This measurement uncertainty is $\pm 0.025 \%$ relative standard deviation (RSD) at the 1 s confidence interval for both the $\mathrm{PuO}_{2}$ and sodalite phase. The measurement uncertainty is shown as the error bars in Fig. 23. The volume increase of both the $\mathrm{PuO}_{2}$ and sodalite phases shown in Fig. 23 are statistically significant. 


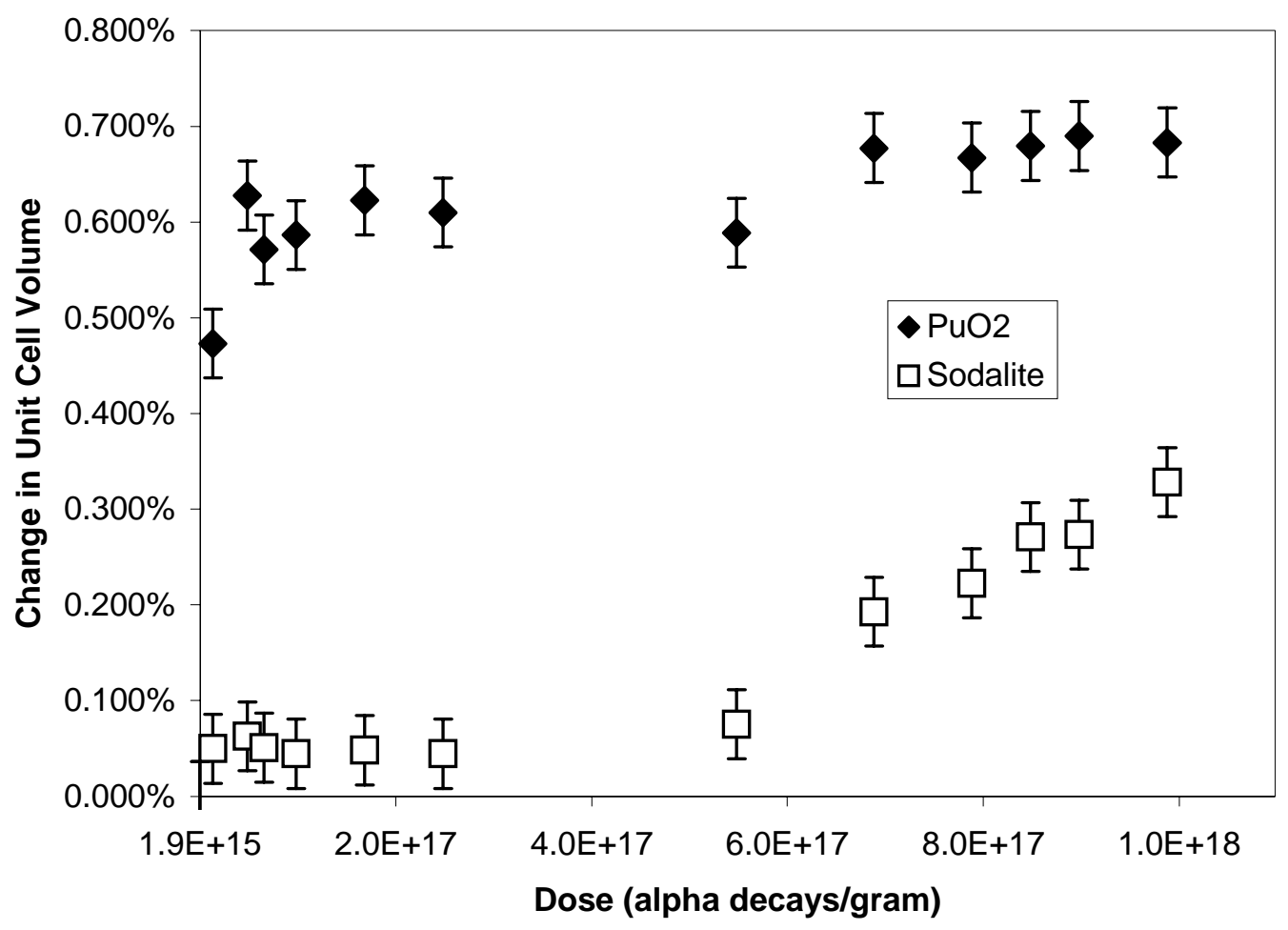

Fig. 23. Unit Cell Volume Increase of $\mathrm{PuO}_{2}$ and Sodalite Phase in ${ }^{238} \mathrm{Pu}-$ loaded CWF with Cumulated Alpha-decay Dose (the volume increase of the $\mathrm{PuO}_{2}$ phase is approximately $0.7 \%$ and $0.3 \%$ for the sodalite phase after a cumulated dose of $1.04 \times 10^{18}$ alpha-decays/gram of material)

The increase in the $\mathrm{PuO}_{2}$ cell volume results from an accumulation of crystal lattice defects induced by alpha decay. This phenomena has been observed elsewhere [30]. The damage results from dissipation of energy from both the alpha particle and the recoil nucleus that emitted the alpha particle. During alpha decay, the alpha particle may have a range of $20 \mathrm{~mm}$ and dissipates its energy to the surrounding matrix by both collision and electronic excitation. The recoiled nucleus has a much shorter range of only tens of nanometers, but dissipates much greater energy and disrupts a large number of neighboring atoms primarily by elastic collisions. For the alpha decay of ${ }^{238} \mathrm{Pu}$ in a crystalline matrix, the ejected alpha particle may dislocate hundreds of matrix atoms by the end of its track. The recoiled ${ }^{234} \mathrm{U}$ nucleus can displace well over 1000 local atoms, depending on the atomic density and displacement energy of the material. Because the ${ }^{238} \mathrm{Pu}$ is localized in the $\mathrm{PuO}_{2}$ phase, the majority of alpha-decay damage from the recoiled ${ }^{234} \mathrm{U}$ nucleus is confined to this phase. Lattice defect damage to the $\mathrm{PuO}_{2}$ phase in the ${ }^{238} \mathrm{Pu}$-loaded CWF has also been observed by high resolution TEM [31]. The significance of the unit-cell volume increase of the $\mathrm{PuO}_{2}$ phase shown in Fig. 22 is that the majority of the volume expansion (less than $1 \%$ ) occurred during the first 100 days with no observed deleterious effect to the physical or chemical durability of the waste form. The $\mathrm{PuO}_{2}$ phase volume is expected to gradually increase 
with the in-growth of ${ }^{234} \mathrm{UO}_{2}\left({ }^{234} \mathrm{U}\right.$ has a larger ionic radius than $\left.{ }^{238} \mathrm{Pu}\right)$ in the solid solution. Indeed the radiation resilient behavior of the $\mathrm{PuO}_{2}$ cubic fluorite-type crystal structure is well known and has been observed in other systems such as $\mathrm{UO}_{2}$ and $\mathrm{ZrO}_{2}$ [32]. This resilience results from the ability of this structure to accommodate defects, especially vacancies.

Figure 23 also shows an apparent sodalite lattice volume increase with accumulated alpha-decay damage, although, to a much less extent than the $\mathrm{PuO}_{2}$ phase $(0.2 \%$ and $0.7 \%$ respectively). The explanation for this volume increase is less obvious as very little Pu has been observed in the sodalite phase itself. While the $\mathrm{PuO}_{2}$ phase is observed to border the sodalite-glass boundaries, the limited range of the ${ }^{234} \mathrm{U}$ recoil nucleus in the $\mathrm{PuO}_{2}$ phase would preclude significant damage to the sodalite crystal structure. Alpha-decay from the Pu-silicate phase, identified by TEM and described previously, would also not be expected to cause significant damage to the separate sodalite phase. A possible explanation for the sodalite volume increase may be the accumulation of He bubbles (alpha particles) in the sodalite phase, or, like the $\mathrm{PuO}_{2}$ phase, an increase in lattice defect damage caused by alpha particles traveling from plutonium decay. Helium bubble formation has been observed in other waste forms containing high activity radionuclides such as ${ }^{238} \mathrm{Pu}$ [33] and, as mentioned previously, TEM investigation of the ${ }^{238} \mathrm{Pu}$-loaded CWF has some preliminary indication of bubble or void formation in the sodalite and glass regions of the waste form. As discussed previously, these void/bubble structures are also observed in the non-Pu CWF material and their origin is unknown, but very likely they are processing artifacts. Helium may also be accumulating in the free volume of the sodalite structure and this may introduce lattice strain to the system. However, no significant peak broadening to the sodalite XRD pattern has been observed after four years that would indicate crystal structure damage from lattice strain.

To place the observed volume increase of the $\mathrm{PuO}_{2}$ and sodalite phases in the ${ }^{238} \mathrm{Pu}$-loaded CWF in perspective, Fig. 23 shows a comparison of the ${ }^{238} \mathrm{Pu}$ CWF to other mineral systems that contain appreciable amounts of actinides for long periods of time. Figure 24 shows the swelling (percent volume increase) relative to cumulated alpha-decay dose for the $\mathrm{PuO}_{2}$ and sodalite phases in the CWF, several synthetic materials and natural 'analog' minerals containing actinides. From this figure it is apparent that the ${ }^{238} \mathrm{Pu}$-loaded CWF, at a cumulated dose of $1.03 \times 10^{18}$ alpha decays/gram of material, experiences minimal swelling resulting from alpha decay and these observations are supported by the invariant density determination of the ${ }^{238} \mathrm{Pu}$ CWF material with accumulated alpha-decay dose. 


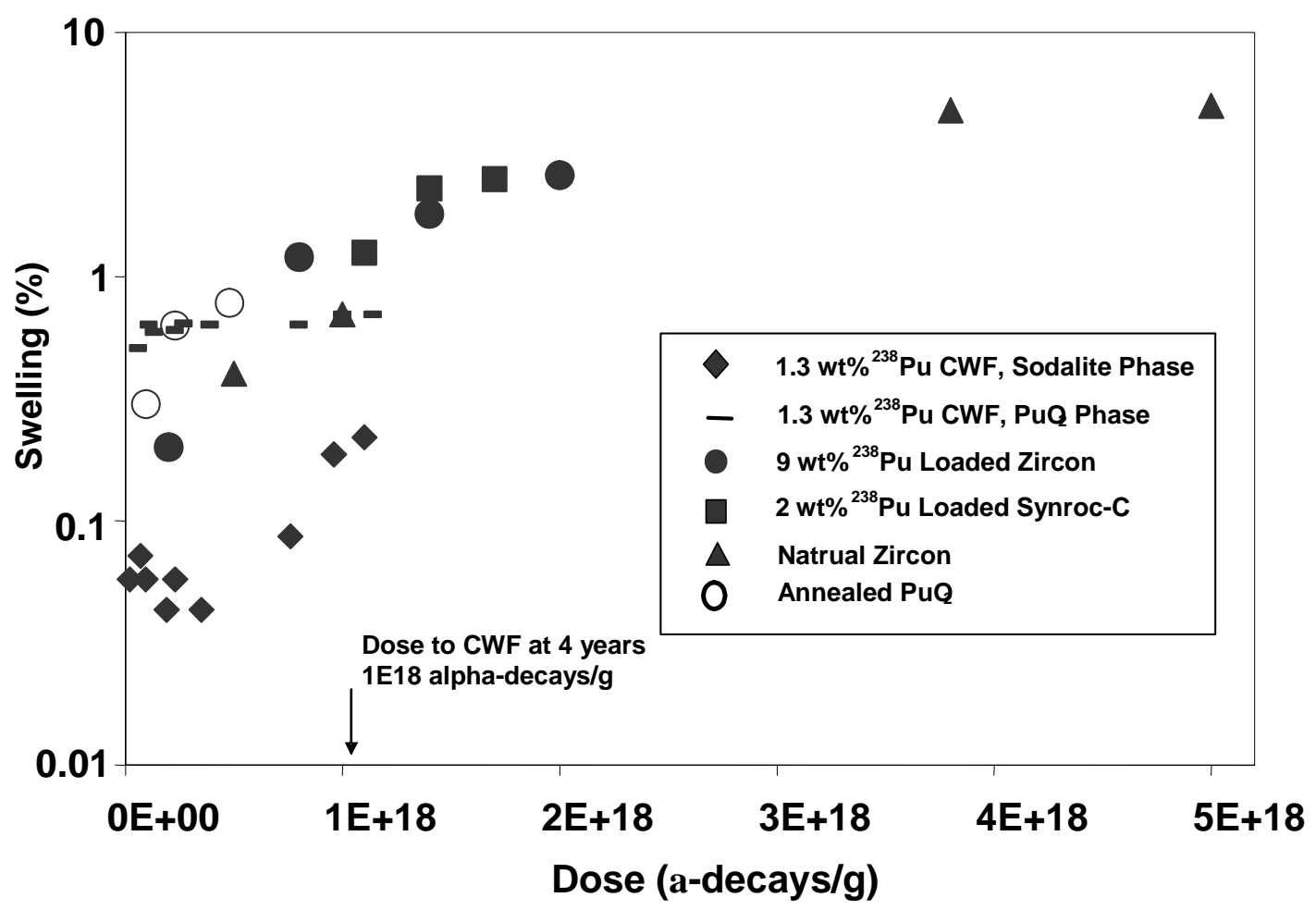

Fig. 24. Swelling (volume percent increase) With Cumulated AlphaDecay Dose for Various Mineral Systems Containing Actinides Including the $\mathrm{PuO}_{2}$ and Sodalite Phases from the ${ }^{238} \mathrm{Pu}$-loaded CWF (also indicated is the cumulated alpha-decay dose of the CWF at one year and four years)

\subsection{Actinide Isotopic Analysis}

At the time of ${ }^{238} \mathrm{Pu}$ preparation and HUP production, ANL-West did not have the analytical or facility capability to perform characterization of the ${ }^{238} \mathrm{Pu}$ feedstock material. However, since that time, new instrumental and method developments have allowed for the isotopic and total actinide measurement of the ${ }^{238} \mathrm{Pu}$ CWF. The results from these measurements are presented here. The measurement of the isotopic and total actinide concentrations in the ${ }^{238} \mathrm{Pu}$ CWF material was necessary to accurately know the total alpha-decay dose acquired by the ${ }^{238} \mathrm{Pu}$ CWF produced from the batch $1 \mathrm{Pu}$-salt/zeolite/glass mixture. In addition to the total and isotopic actinide concentrations of batch 1 material, the surrogate fission product elements, originally added to the eutectic salt to simulated 100-driver electrorefiner salt, were also measured. Table 14 shows the total actinide concentration found in the ${ }^{238} \mathrm{Pu}$ CWF HUP material produced from batch 1 . Table 15 shows the isotopic ratios for the actinides listed in Table 14 . While the expected plutonium concentration in batch 1 material of approximately $3.2 \mathrm{wt} \%$ matched the measured quantity of $3.28 \mathrm{wt} \%$ quite well, the measured ${ }^{238} \mathrm{Pu}$ concentration of $1.27 \mathrm{wt} \%$ was much less than the expected value of $2.80 \mathrm{wt} \%$. Possible explanations for this discrepancy are discussed in the Appendix at the end of this report. Finally, Table 16 shows the 
measured and expected concentration of the surrogate fission product elements in the ${ }^{238} \mathrm{Pu} \mathrm{CWF}$ material.

Table 14. Actinide Concentration in Batch $1{ }^{238} \mathrm{Pu}-\mathrm{CWF}$ Material (concentrations are average of duplicate analyses, measurement uncertainty $\pm 10 \%$ RSD)

\begin{tabular}{|l|c|c|c|c|}
\hline & Uranium & Neptunium & Plutonium & Americium \\
\hline \hline Concentration (wt\%) & 0.27 & 0.32 & 3.28 & $65 \mathrm{ppm}$ \\
\hline
\end{tabular}

Table 15. Percent Isotopic Composition of Uranium and Plutonium from Batch $1{ }^{238} \mathrm{Pu}-\mathrm{CWF}$ Material (concentrations are average of duplicate analyses, measurement uncertainty $\pm 10 \%$ RSD)

\begin{tabular}{|l|c|c|c|c|c|c|c|c|c|}
\hline \multicolumn{1}{|c|}{ Mass Number } & 233 & 234 & 235 & 236 & 238 & 239 & 240 & 241 & 242 \\
\hline \hline Uranium & 0.518 & 87.3 & 1.64 & 0.718 & 9.80 & & & & \\
\hline Plutonium & & & & & 38.7 & 54.6 & 6.38 & 0.216 & 0.074 \\
\hline
\end{tabular}

Table 16. Comparison of As Batched Concentration to the Measured Concentration of Surrogate Fission-product Elements (parts per million) in Batch $1{ }^{238} \mathrm{Pu}-\mathrm{CWF}$ Material (measured concentrations are average of duplicate analyses, measurement uncertainty $\pm 10 \%$ RSD)

\begin{tabular}{|l|c|c|c|c|c|c|c|c|c|}
\hline \multicolumn{1}{|c|}{ Element } & $\mathrm{Rb}$ & $\mathrm{Sr}$ & $\mathrm{Y}$ & $\mathrm{Cs}$ & $\mathrm{Ba}$ & $\mathrm{La}$ & $\mathrm{Ce}$ & $\mathrm{Nd}$ & $\mathrm{Sm}$ \\
\hline \hline Batch Concentration & 69 & 168 & 96 & 598 & 238 & 209 & 401 & 677 & 12.1 \\
\hline Measured Concentration & 51.2 & 284 & 46.0 & 1070 & 344 & 182 & 399 & 746 & 50.2 \\
\hline
\end{tabular}

A greater emphasis was placed on the need to determine the actinide content of the ${ }^{238} \mathrm{Pu} C W F$ material after analysis of the PCT results. The measurement of the leachate from the PCT indicated the presence of $U$ in the HUP material, yet mass spectral analysis could not resolve ${ }^{238} \mathrm{Pu}$ from ${ }^{238} \mathrm{U}$, and as mentioned, this called into question the total dose that the ${ }^{238} \mathrm{Pu} \mathrm{CWF}$ material had acquired during the four year testing campaign. These results show that while the total quantity of $\mathrm{Pu}$ was near to the expected value estimated during HUP processing, the total quantity of ${ }^{238} \mathrm{Pu}$ was less than expected. The alpha-decay dose expressed in this report is based on the measured quantity of ${ }^{238} \mathrm{Pu}$ present in the batch 1 material. Also, the measured quantity of $\mathrm{U}$ present in the sample was small and did not significantly influence the release data from the PCT results. Finally, the high concentration of ${ }^{234} \mathrm{U}$ shown in Table 15 results from the alpha decay of ${ }^{238} \mathrm{Pu}$. 


\subsection{CONCLUSIONS}

The four year CWF alpha-decay damage study was recently completed with a total cumulated dose to the waste form of $1.04 \times 10^{18}$ alpha-decays/gram of material. Very little alteration to the waste form was observed during the test period. The major observations from this study are as follows:

- The chemical durability of the ${ }^{238} \mathrm{Pu} \mathrm{CWF}$, indicated by the elemental release during the PCT leach method, has varied little from the initial testing period. The release of matrix elements $\mathrm{Si}, \mathrm{Al}$ and $\mathrm{B}$ has not changed after 4 years of exposure. The release of $\mathrm{Na}, \mathrm{Cl}$ and $\mathrm{Pu}$ increased with accumulated alpha-decay damage, but the Pu release is still extremely low at less than $0.005 \mathrm{~g} / \mathrm{m}^{2}$. Furthermore, the elemental release of matrix components $\mathrm{Si}, \mathrm{Al}$ and $\mathrm{B}$ from the Pu-loaded CWF is comparable to or less than the release of these elements from the CWF is comparable to or less than the release of these elements from the CWF with no plutonium and much less than the release of $\mathrm{Si}, \mathrm{Al}$ and $\mathrm{B}$ from the benchmark $\mathrm{EA}$ borosilicate glass reference material.

- $\quad$ The density of the ${ }^{238} \mathrm{Pu}$ CWF has not changed within experimental uncertainty during four years of measurement.

- $\quad$ The phase composition of the ${ }^{238} \mathrm{Pu}$ CWF has remained constant with increasing alpha-decay damage. Within 100 days of ${ }^{238} \mathrm{Pu}$ CWF production, the $\mathrm{PuO}_{2}$ phase under went the expected unit-cell volume increase due to the accumulation of lattice defects from alpha-decay. This expansion of approximately $0.7 \%$ has not caused any deleterious affects to the waste form. The unit-cell volume of the sodalite phase is also increasing, but at a much smaller extent (0.3\%) than the $\mathrm{PuO}_{2}$ volume increase, again with no deleterious affects observed.

- $\quad$ No microcracks, phase debonding or crystalline phase amorphization were found in the ${ }^{238} \mathrm{Pu}$ bearing ceramic waste form samples aged for four years.

- $\quad$ In some areas of the ${ }^{238} \mathrm{Pu}$ doped ceramic waste form samples after aging, bubbles and voids were found. Bubbles and voids with similar size and density were also found in ceramic waste form samples without actinide. These bubbles and voids are interpreted as pre-existing defects. However, some contribution to these bubbles and voids from helium gas can not be ruled out.

\subsection{Recommendations}

It is recommended that observations of the ${ }^{238} \mathrm{Pu}$ CWF material be continued beyond the four year test period due to the lower than expected quantity of ${ }^{238} \mathrm{Pu}$ in the waste form, particularly with reaspect to the chemical durability of the CWF and Pu release as a function of accumulated alpha-decay damage. A longer test period would increase the alpha radiation damage to the CWF 
to a level originally planned at the start of these experiments. The test specimens and required equipment are available for continued testing and would require only minimal effort for continued analysis. While it has been shown that the CWF remains durable after an exposure of

approximately

$1 \times 10^{18}$ alpha-decays/g of material, it is apparent that greater radiation exposure will be required to observe if any significant degradation to the waste form occurs.

\section{ACKNOWLEDGEMENTS}

This work was supported by the U.S. Department of Energy, Nuclear Energy Research and Development Program, under Contract No. W-31-109-ENG-38. Special thanks to R. N. Elliot, C. L. Brower and J. Colborn for hot cell sample preparation, P. J. Crane for assistance in chemical analysis, and P. Hansen for pellet preparation. 


\section{REFERENCES}

1. R. W. Benedict and H. F. McFarlane, "EBR-II Spent Fuel Treatment Demonstration," Radwaste Management, 5:23 (1998).

2. K. M. Goff, R. W. Benedict, K. Bateman, M. A. Lewis, C. Pereira, C. A. Musick, "Ceramic Waste Form Production and Testing at Argonne National Laboratory-West," Proceedings of the Third Topical Meeting on DOE Spent Nuclear Fuel and Fissile Material Management, American Nuclear Society, Charleston, SC (September 8-11, 1998).

3. M. F. Simpson, K. M. Goff, S. G. Johnson, T. J. Bateman, T. L. Moschetti, T. J. Battisti, K. L. Toews, S. M. Frank, T. L. Moschetti, T. P. O’Holleran and W. Sinkler, “A Description of the Ceramic Waste Form Production Process from the Demonstration Phase of the Electrometallurgical Treatment of EBR-II Spent Fuel,” Nuclear Technology, 134:263 (2001).

4. J. P. Ackerman, S. M. McDeavitt, C. Pereira, and L. J. Simpson, "Waste Form Development and Characterization in Pyrometallurgical Treatment of Spent Nuclear Fuel,” Proceedings of Third Topical Meeting DOE Spent Nuclear Fuel and Fissile Materials Management, American Nuclear Society, Charleston, SC, 699 (September 8-11,1998).

5. N. E. Bibler and J. K. Bates, "Product Consistency Leach Test of Savannah River Site Radioactive Waste Glasses,” Materials Research Society Symposium Proceedings, 176:327 (1990).

6. Office of Civilian Radioactive Waste Management, "Waste Acceptance System Requirements Document,” U.S. Department of Energy, E00000000-00811-1708-00001, rev. 2 (1996).

7. W. J. Weber, “Alpha-Decay-Induced Amorphization in Complex Silicate Structures,” Journal of the American Ceramic Society, 76 [7]:1729-38 (1993).

8. F. W. Clinard Jr., E. M. Foltyn and R. C. Ewing, "Stored Energy in Natural Zirconolite and its Synthetic Counterpart after Alpha Recoil Self-Irradiation Damage,” Journal of Nuclear Materials, 185:202-207 (1991).

9. B. G. Storey and T. R. Allen, "Radiation Damage of a Glass-Bonded Zeolite Waste Form Using Ion Irradiation,” Materials Research Society Symposium Proceedings, 481:413 (1998).

10. G. R. Lumpkin, R. C. Ewing, B. C. Chakoumakos, R. B. Greegor, F. W. Lytle, E. M. Foltyn, F. W. Clinard, Jr., L. A. Boatner and M. M. Abraham, “Alpha-Recoil Damage in Zirconolite $\left(\mathrm{CaZrTiO}_{7}\right)$,” Materials Research Society Symposium Proceedings, 1:564 (1986).

11. R. C. Ewing, W. J. Weber and F. W. Clinard, Jr., "Radiation Effects in Nuclear Waste Forms for High-Level Radioactive Waste,” Progress in Nuclear Energy, 29:63 (1995). 
12. K. A. Boult, J. T. Dalton, J. P. Evans, A. R. Hall, A. J. Inns, J. A. C. Marples and E. L. Paige, “The Preparation of Fully Active Synroc and Its Radiation Stability,” Harwell Laboratory Report, AERE-R-13318, Harwell, UK (October 1988).

13. A. G. Solomah and H. Matzke, "Leaching Studies of Synroc Crystalline Ceramic Waste Forms,” Materials Research Society Symposium Proceedings, 127:241 (1989).

14. W. J. Weber, R. C. Ewing, C. R. A. Catlow, T. Diaz de la Rubia, L. W. Hobbs, C. Kinoshita, Hj. Matzke, A. T. Motta, M. Nastasi, E. K. H. Salje, E. R. Vance and S. J. Zinkle, "Radiation Effects in Crystalline Ceramics for the Immobilization of High-Level Nuclear Waste and Plutonium,” Materials Research Society Symposium Proceedings, 13:1432 (1998).

15. American Society of Testing Materials, Annual Book of ASTM Standards, "Standard Test Methods for Determining Chemical Durability of Nuclear Waste Glasses and Ceramics: The Product Consistency Test (PCT),” C1285-02, Philadelphia, PA, (2002).

16. A. C. Larson and R. B. Von Dreele, “General Structure Analysis System,” Los Alamos National Laboratory Report, LAUR86-748 (1986).

17. SIROQUANT Software, version 2, Sietronics LTD., Belconnen, Australia.

18. W. Sinkler, T. P. O’Holleran, T. L. Moschetti and S. M. Frank to S. G. Johnson, Argonne National Laboratory-West, personal communication (1999).

19. T. P. O’Holleran and T. L. Moschetti to S. G. Johnson, Argonne National Laboratory-West, personal communication (1998).

20. D. G. Howitt, H. W. Chan, J. F. DeNatale, and J. P. Heuer, "Mechanism for the Radiolytically Induced Decomposition of Soda-Silicate Glasses,” Journal of the American Ceramic Society, 74:1145 (1991).

21. E. Johnson, J. Ferrer, and L. T. Chadderton, "Radiolytic Radiation Damage of Sodalite," Physica Status Solidi, (a)49:585 (1978).

22. R. B. Roof, “X-Ray Diffraction Data for Plutonium Compounds,” Los Alamos National Laboratory Report, LAUR 11619 (1989).

23. W. H. Zachariasen, "Crystal Chemical Studies of the 5f-Series of Elements: XII New Compounds Representing Known Structure Types,” Acta Crystallographica, 2:388 (1949).

24. P. Villars and L. D. Calvert, "Pearson's Handbook of Crystallographic Data for Intermetallic Phases,” $2^{\text {nd }}$ Edition, ASM International, Metals Park, OH (1985). 
25. W. L. Ebert, M. A. Lewis and S. G. Johnson, “The Precision of Product Consistency Tests Conducted with a Glass-Bonded Ceramic Waste Form,” Journal of Nuclear Materials, 305:37 (2002).

26. P. W. Levy, "Review of Nuclear Radiation Damage Process: Phenomenological Features of Radiation Damage in Crystals and Glasses," SPIE, Radiation Effects in Optical Materials Proceedings, 541:2 (1985).

27. S. Sato, H. Furuya, T. Kozaka, Y. Inagaki and T. Tamai, "Volumetric Change of Simulated Radioactive Waste Glasses Irradiated by the ${ }^{10} \mathrm{~B}(\mathrm{n}, \mathrm{a}){ }^{7} \mathrm{Li}$ Reaction as Simulation of Actinide Irradiation,” Journal of Nuclear Materials, 152:265 (1988).

28. L. R. Morss, et al., "Corrosion Test with Uranium and Plutonium-Loaded Ceramic Waste Forms,” Argonne National Laboratory Report ANL-02/9 (April 2002).

29. International Centre for Diffraction Data, Powder Diffraction File, Newtown Square, PA (1995).

30. T. D. Chikalla and R. P. Turcotte, “Self-Radiation Damage Ingrowth in ${ }^{238} \mathrm{PuO}_{2}$," Radiation Effects, 19:93 (1973).

31. S. M. Frank, S. G. Johnson, T. L. Moschetti, T. P. O’Holleran, W. Sinkler, K. M. Goff and D. W. Esh, “Accelerated Alpha Radiation Damage in a Ceramic Waste Form, Interim Results,” Materials Research Society Symposium Proceedings, 608:469 (2000).

32. W. J. Weber, "Ingrowth of Lattice Defects in Alpha Irradiated $\mathrm{UO}_{2}$ Single Crystals," Journal of Nuclear Materials, 98:206 (1981).

33. Y. Inagaki, H. Furuya, and K. Idemitsu, "Microstructure and Simulated High-Level Waste Glass Doped with Short-Lived Actinides, ${ }^{238} \mathrm{Pu}$ and ${ }^{244} \mathrm{Cm}$,” Materials Research Society Symposium Proceedings, 257:199 (1992). 


\section{APPENDIX A}

\section{Process Loss of Plutonium}

As reported in the previous section, the quantity of ${ }^{238} \mathrm{Pu}$ in the HUPed material was less than expected from process information at the time of HUP production. Significant effort was directed to develop process models to calculate the total and isotopic Pu concentrations in the ${ }^{238} \mathrm{Pu}-\mathrm{CWF}$ material in lieu of actual measurement data. The following discussion explains how these models were developed, what assumptions were used, and possible scenarios explaining the discrepancy between the expected and actual ${ }^{238} \mathrm{Pu}$ concentration measured in the ${ }^{238} \mathrm{Pu}-\mathrm{CWF}$ material. ANL-West received two ${ }^{238} \mathrm{Pu}$ feedstock items from LANL for use in the ${ }^{238} \mathrm{Pu}$ doped ceramic waste form tests. The shipping documents from LANL stated that the two Pu items had masses of $1.814 \mathrm{~g}( \pm 0.018 \mathrm{~g})$ and $1.918 \mathrm{~g}( \pm 0.018 \mathrm{~g})$, however, the items weighed to $1.959 \mathrm{~g}$ and $2.066 \mathrm{~g}$ upon receipt at ANL-West. Although reported that only metallic pieces were loaded at LANL for shipping, visual inspection of the received material revealed the presence of non-metallic powder. The problem is how to reconcile the difference between the shipped and the received masses.

It is suggested that the increase in mass is due to the formation of oxides during storage in the shipped containers. This is not an unreasonable suggestion considering the mass increases are about the same ( $0.145 \mathrm{~g}$ and $0.148 \mathrm{~g})$ and correspond to volumes of air of about 530 and $540 \mathrm{cc}$ $\left(25^{\circ} \mathrm{C}, 1 \mathrm{~atm}\right.$. air @ $\left.21 \mathrm{vol} \% \mathrm{O}_{2}\right)$. For comparison, a 5 in. $(12.7 \mathrm{~cm})$ tall, 3 in. $(7.6 \mathrm{~cm})$ diameter volume encases $580 \mathrm{~cm}^{3}$. This is the approximate volume of a standard shipping container.

In the case of oxide formation, the limiting reactant is oxygen. The energies of formation for the two stabile oxides of $\mathrm{Pu}$ at $30^{\circ} \mathrm{C}$ are about $\mathrm{DG}_{\mathrm{f}}=-275 \mathrm{kcal} / \mathrm{mole}_{2} \mathrm{O}_{2}\left(\mathrm{Pu}_{2} \mathrm{O}_{3}\right)$ and $\mathrm{DG}_{\mathrm{f}}=-240 \mathrm{kcal} / \mathrm{mole} \mathrm{O}_{2}\left(\mathrm{PuO}_{2}\right)$ and at $500^{\circ} \mathrm{C}$ are about $\mathrm{DG}_{\mathrm{f}}=-255 \mathrm{kcal} / \mathrm{mole}_{2}\left(\mathrm{Pu}_{2} \mathrm{O}_{3}\right)$ and $\mathrm{DG}_{\mathrm{f}}=-220 \mathrm{kcal} / \mathrm{mole} \mathrm{O}_{2}\left(\mathrm{PuO}_{2}\right)$. Although under these formation conditions $\mathrm{Pu}_{2} \mathrm{O}_{3}$ is the thermodynamically stable product, it can not be ruled out that $\mathrm{PuO}_{2}$ would also form due to the closeness of its formation free energy and the change in conditions to an oxidizing environment when the excess $\mathrm{FeCl}_{2}$ is present. In addition, during the Pu metal oxidation by $\mathrm{FeCl}_{2}$ at elevated temperatures a possibility exists for the formation of the intermetallic $\mathrm{Fe}_{2} \mathrm{Pu}$. Although in the presence of excess $\mathrm{FeCl}_{2}$ the formation of $\mathrm{PuCl}_{3}$ over $\mathrm{Fe}_{2} \mathrm{Pu}$ from Pu metal is strongly favored thermodynamically, the possible occurrence of $\mathrm{Fe}_{2} \mathrm{Pu}$ was considered.

The process to create samples of the waste form proceeded according to the following. Quantities of $\mathrm{LiCl} / \mathrm{KCl}$ eutectic, excess $\mathrm{FeCl}_{2}$ and all the received ${ }^{238} \mathrm{Pu}$ material were weighed and mixed. This mixture was heated (to melt the eutectic salt) and mechanically stirred for a period of time to allow the oxidation of Pu metal by $\mathrm{FeCl}_{2}$ according to Eqn. (1).

$$
2 \mathrm{Pu}(\mathrm{m})+3 \mathrm{FeCl}_{2} \rightarrow 2 \mathrm{PuCl}_{3}+3 \mathrm{Fe}(\mathrm{m})
$$


After sufficient reaction time the mechanical stirrer was raised out of the reaction vessel and allowed to drip adhered material back into the reaction vessel at temperature. During this period, the "solution" in the reaction vessel was heated but unstirred. The "solution" was then allowed to cool to room temperature (whereby the salt froze), was removed from the reaction vessel and crushed and ground to a powder. A technique was then performed to remove the Fe metal by magnetic separation. Some salt was carried along with the Fe, which would then eventually be reprocessed to reclaim any $\mathrm{Pu}$. The material left over from the magnetic separation was the product. A sample was removed from the product for future analysis. At this stage four fractions are identified: product, analysis sample, magnetic separation and loss. The masses of the first three were measured and the mass of the loss fraction determined as difference between input feed masses and the sum of the 3 fractions measured to this point. The product now contains some $\mathrm{FeCl}_{3}$ since excess was used. The entire product mass is now added to a reaction vessel and charged with a larger piece of ${ }^{239} \mathrm{Pu}$ metal to perform a second Pu oxidation step. This is heated and allowed to react with mechanical stirring according to Eqn (1). Once again the stirring is stopped and the stirrer raised from the solution under heating, allowed to sit for awhile, cooled, and removed for further processing of crushing, grinding and magnetic separation. After this another set of fractions have been produced: final product, analysis sample, magnetic separation and loss, and in addition the unreacted portion of the ${ }^{239} \mathrm{Pu}$ metal piece is removed and weighed. The final product is then taken, mixed with portions of zeolite and glass, heated under uniaxial pressure and transformed into the desired waste form samples.

In order to determine/verify the amount of ${ }^{238} \mathrm{Pu}$ metal vs. Pu oxide entering the process, the amount of reacted ${ }^{238} \mathrm{Pu}$ was back calculated and compared to the amount of oxygen reacted that apparently caused the mass increase of the received material. This calculation proceeded according to the following logic. The assumptions made at this point for the calculations include: all Fe metal is removed from the product to the magnetic separation fraction. The loss fraction contains a relative percentage of all components according to the loss mass and total input mass. Except for the loss fraction, dissolved concentrations are the same in all fractions.

The second oxidation step adds ${ }^{239} \mathrm{Pu}$ to the product and the amount of ${ }^{239} \mathrm{Pu}$ reacted (determined from the difference between the measured masses of the ${ }^{239} \mathrm{Pu}$ piece before and after reaction) gives the amount of $\mathrm{FeCl}_{2}$ in the product from the first ${ }^{238} \mathrm{Pu}$ oxidation. From this the amount of $\mathrm{FeCl}_{2}$ in the analysis sample can be determined via mass proportions. In order to determine the total amount of $\mathrm{FeCl}_{2}$ consumed to form Fe metal in the first oxidation the following relationships are established.

Let $\mathrm{x}=$ mass $\mathrm{FeCl}_{2}$ in $1^{\text {st }}$ oxidation magnetic separation fraction

Let $\mathrm{y}=$ mass $\mathrm{FeCl}_{2}$ in $1^{\text {st }}$ oxidation loss

Let $\mathrm{z}=$ mass $\mathrm{FeCl}_{2}$ converted to Fe metal in $1^{\text {st }}$ oxidation

Then 


$$
\begin{aligned}
& \mathrm{x}+\mathrm{y}+\mathrm{z}=\left(\text { mass of } \mathrm{FeCl}_{2} \text { input }\right)-\left(\text { mass } \mathrm{FeCl}_{2} \text { in product fraction }\right) \\
& -\left(\text { mass } \mathrm{FeCl}_{2} \text { in analysis sample }\right)
\end{aligned}
$$

Since the loss is assumed to be the same percentage for all species then;

$$
\begin{aligned}
& \mathrm{y}=\text { loss fractional percentage } *\left(\mathrm{x}+\mathrm{y}+\left(\text { mass } \mathrm{FeCl}_{2} \text { in product fraction }\right)\right. \\
& \left.+\left(\text { mass } \mathrm{FeCl}_{2} \text { in analysis sample }\right)\right)
\end{aligned}
$$

Let $\mathrm{t}=$ total mass of Fe metal formed in $1^{\text {st }}$ oxidation

Let $\mathrm{n}=$ mass Fe metal in loss

Let $\mathrm{m}=$ mass Fe metal in magnetic separation

Let $\mathrm{p}=$ mass Pu oxide in magnetic separation

Let $\mathrm{q}=$ mass $\mathrm{Pu}$ oxide in product

Since 1 mole of Fe metal is formed for every mole of $\mathrm{FeCl}_{2}$ consumed, the total mass Fe metal produced in the first oxidation (Eqn. 4) and its amounts found in the loss (Eqn. 5) and magnetic separation (Eqn. 6) are given below.

$$
\begin{gathered}
\mathrm{t}=\mathrm{z} *\left(\mathrm{M} \cdot \mathrm{W} . \mathrm{Fe} / \mathrm{M} \cdot \mathrm{W} \cdot \mathrm{FeCl}_{2}\right) \\
\mathrm{n}=\text { loss fractional percentage } * \mathrm{t} \\
\mathrm{m}=(1-\text { loss fractional percentage }) * \mathrm{t}
\end{gathered}
$$

since the Fe metal is found only in the loss and the magnetic separation fractions. Again, assuming all dissolved concentrations $\left(\mathrm{FeCl}_{2}\right.$ and $\left.\mathrm{PuCl}_{3}\right)$ are the same in all fractions, the ratios hold for

$$
\begin{gathered}
\mathrm{x} /(\text { total magnetic separation mass }-\mathrm{m}-\mathrm{p})= \\
\text { mass } \left.\mathrm{FeCl}_{2} \text { in product / (total product mass }-\mathrm{q}\right)
\end{gathered}
$$

Equations (2), (3), (6) and (7) can now be used to solve for $\mathrm{x}, \mathrm{y}$ and $\mathrm{z}$ (the $\mathrm{FeCl}_{2} \mathrm{masses}_{\text {). }}$ Equations (4), (5) and (6) can then be used to solve for t, $\mathrm{n}$ and $\mathrm{m}$ (the masses Fe metal). The equations are then iterated over input values of the amount of Pu metal in the feedstock material with the $\mathrm{p}$ and $\mathrm{q}$ to produce results that give the proper ratio of oxygen to $\mathrm{Pu}$ for the model oxide and the correct amount of total mass in each fraction. The totals from either the $\mathrm{FeCl}_{2}$ consumed or Fe metal produced are used in conjunction with Eqn. 1 to determine the total ${ }^{238} \mathrm{Pu}$ metal consumed. Thus, the amount of Pu oxide in the individual fractions is allowed to vary. The only constraints is the amount of $\mathrm{FeCl}_{2}$ in the $1^{\text {st }}$ oxidation product is set by the measured ${ }^{239} \mathrm{Pu}$ metal consumed in the $2^{\text {nd }}$ oxidation, the concentrations of all the dissolved species are the same in all fractions in each oxidation step, the Fe metal produced is restricted to the loss and magnetic 
separation fractions and no isotopic exchange occurs. Similar considerations will yield the values for the $\mathrm{PuCl}_{3}$.

The results from two models are presented below and represent boundaries for the process chemistry. The first model considers $\mathrm{Pu}_{2} \mathrm{O}_{3}$ as the oxide formed and the second considers $\mathrm{PuO}_{2}$ as the oxide formed in the shipped material. For either the formation of $\mathrm{PuO}_{2}$ or $\mathrm{Pu}_{2} \mathrm{O}_{3}$, the amount of ${ }^{238} \mathrm{Pu}$ metal initially present in the LANL material determined from this analysis is 1.813 grams for Batch 1 (Batch 008) and 1.918 grams for Batch 2 (Batch 009), both well within the error limits of the 1.814 grams and 1.918 grams determined by LANL for shipping. From these values, different amounts of metal would be available for oxidation to $\mathrm{PuCl}_{3}$. Table $1 \mathrm{~A}$ lists the mass values of the resulting species per fraction for the Batch 1 (Batch 008) oxidation process resulting from the model where only $\mathrm{Pu}_{2} \mathrm{O}_{3}$ is formed as the oxide in the ${ }^{238} \mathrm{Pu}$ feedstock. Surprisingly, the analysis results in an even distribution of the $\mathrm{Pu}_{2} \mathrm{O}_{3}$ species throughout the different fractions during the oxidation process step.

Table 1A. Component Masses (grams) of Fractions According to Process Chemistry Analysis Based on $\mathrm{Pu}_{2} \mathrm{O}_{3}$ Formation Model

\begin{tabular}{|l|c|c|c|c|c|c|c|c|c|}
\hline & Total & $\begin{array}{c}{ }^{238} \mathrm{Pu} \\
\mathrm{Metal}\end{array}$ & ${ }^{238} \mathrm{Pu}_{2} \mathrm{O}_{3}$ & $\mathrm{FeCl}_{2}$ & $\begin{array}{c}\mathrm{LiCl} / \\
\mathrm{KCl}\end{array}$ & $\begin{array}{c}\mathrm{Fe} \\
\text { Metal }\end{array}$ & ${ }^{238} \mathrm{PuCl}_{3}$ & $\begin{array}{c}{ }^{239} \mathrm{Pu} \\
\mathrm{Metal}\end{array}$ & ${ }^{239} \mathrm{PuCl}_{3}$ \\
\hline \hline $\begin{array}{l}\text { 1st } \\
\text { oxidation } \\
\text { input } \\
\text { masses }\end{array}$ & 6.109 & 0.367 & 1.592 & 1.558 & 2.592 & & & & \\
\hline $\begin{array}{l}\text { 1st } \\
\text { oxidation } \\
\text { product }\end{array}$ & 3.285 & & 0.875 & 0.695 & 1.424 & & 0.292 & & \\
\hline $\begin{array}{l}\text { 1st } \\
\text { oxidation } \\
\text { analysis } \\
\text { sample }\end{array}$ & 0.043 & & 0.011 & 0.009 & 0.019 & & 0.004 & & \\
\hline $\begin{array}{l}\text { 1st } \\
\text { oxidation } \\
\text { magnetic } \\
\text { separation }\end{array}$ & 2.393 & 0.604 & 0.481 & 0.985 & 0.121 & 0.202 & & & \\
\hline $\begin{array}{l}\text { 1st } \\
\text { oxidation } \\
\text { loss }\end{array}$ & 0.387 & & 0.101 & 0.080 & 0.164 & 0.008 & 0.034 & & \\
\hline
\end{tabular}


Table 1A. (Contd.)

\begin{tabular}{|l|c|c|c|c|c|c|c|c|c|}
\hline & Total & $\begin{array}{c}{ }^{238} \mathrm{Pu} \\
\mathrm{Metal}\end{array}$ & ${ }^{238} \mathrm{Pu}_{2} \mathrm{O}_{3}$ & $\mathrm{FeCl}_{2}$ & $\begin{array}{c}\mathrm{LiCl} / \\
\mathrm{KCl}\end{array}$ & $\begin{array}{c}\mathrm{Fe} \\
\text { Metal }\end{array}$ & ${ }^{238} \mathrm{PuCl}_{3}$ & $\begin{array}{c}{ }^{239} \mathrm{Pu} \\
\text { Metal }\end{array}$ & ${ }^{239} \mathrm{PuCl}_{3}$ \\
\hline $\begin{array}{l}\text { 2nd } \\
\text { oxidation } \\
\text { input } \\
\text { masses }\end{array}$ & 4.159 & & 0.875 & 0.695 & 1.424 & & 0.292 & 0.874 & \\
\hline $\begin{array}{l}\text { 2nd } \\
\text { oxidation } \\
\text { product }\end{array}$ & 2.859 & & 0.649 & & 1.057 & & 0.216 & & 0.937 \\
\hline $\begin{array}{l}\text { 2nd } \\
\text { oxidation } \\
\text { analysis } \\
\text { sample }\end{array}$ & 0.051 & & 0.012 & & 0.019 & & 0.004 & & 0.017 \\
\hline $\begin{array}{l}\text { 2nd } \\
\text { oxidation } \\
\text { magnetic } \\
\text { separation }\end{array}$ & 0.78 & & 0.115 & & 0.188 & 0.272 & 0.038 & & 0.167 \\
\hline $\begin{array}{l}\text { 2nd } \\
\text { oxidation } \\
\text { loss }\end{array}$ & 0.469 & & 0.099 & & 0.161 & 0.035 & 0.033 & & 0.142 \\
\hline
\end{tabular}

Table 2A lists the isotopic breakdown and mass fractions in the various process steps for the model described in Table 1A. Table 2A shows that the total Pu content of the ceramic waste form is about $4 \%$ of the mass. To be noted is that the ${ }^{238} \mathrm{Pu}:{ }^{239} \mathrm{Pu}$ ratio is about $1: 1$ and that the ${ }^{238} \mathrm{Pu}$ makes up about $1.9 \%$ of the mass of the final ceramic waste form.

Table 2A. Weight Fractions of Pu Isotopes and Total Pu in Products of Process Steps to Form Ceramic Waste Form Based on $\mathrm{Pu}_{2} \mathrm{O}_{3}$ Formation Model

\begin{tabular}{|l|c|c|c|c|}
\hline & $\begin{array}{c}\text { Mass Final } \\
\text { Product Oxidation } \\
\text { Process }\end{array}$ & $\begin{array}{c}\text { Relative Isotope } \\
\text { Fraction in Final } \\
\text { Oxidation Process }\end{array}$ & $\begin{array}{c}\text { Weight Fraction } \\
\text { of Pu in Zeolite } \\
\text { Contact Process }\end{array}$ & $\begin{array}{c}\text { Weight Fraction in } \\
\text { Final Zeolite/Glass/ } \\
\text { Salt Mixture }\end{array}$ \\
\hline \hline${ }^{238} \mathrm{Pu}$ & 0.65347 & 0.47081 & 0.02523 & 0.01892 \\
\hline${ }^{239} \mathrm{Pu}$ & 0.65089 & 0.46895 & 0.02513 & 0.01885 \\
\hline${ }^{240} \mathrm{Pu}$ & 0.07834 & 0.05644 & 0.00302 & 0.00227 \\
\hline${ }^{241} \mathrm{Pu}$ & 0.00365 & 0.00263 & 0.00014 & 0.00011 \\
\hline
\end{tabular}


Table 2A. (Contd.)

\begin{tabular}{|l|c|c|c|c|}
\hline & $\begin{array}{c}\text { Mass Final } \\
\text { Product Oxidation } \\
\text { Process }\end{array}$ & $\begin{array}{c}\text { Relative Isotope } \\
\text { Fraction in Final } \\
\text { Oxidation Process }\end{array}$ & $\begin{array}{c}\text { Weight Fraction } \\
\text { of Pu in Zeolite } \\
\text { Contact Process }\end{array}$ & $\begin{array}{c}\text { Weight Fraction in } \\
\text { Final Zeolite/Glass/ } \\
\text { Salt Mixture }\end{array}$ \\
\hline \hline${ }^{242} \mathrm{Pu}$ & 0.00163 & 0.00118 & 0.00006 & 0.00005 \\
\hline Total $\mathrm{Pu}$ & 1.38798 & 1.00000 & 0.05358 & 0.04019 \\
\hline
\end{tabular}

Table 3A lists the mass values of the resulting species per fraction for the Batch 1 (Batch 008) oxidation process resulting from the model where only $\mathrm{PuO}_{2}$ is formed as the oxide in the ${ }^{238} \mathrm{Pu}$ feedstock. Once again an interesting result comes from the analysis: virtually no oxide is carried into the products of the two oxidation steps. The amount of ${ }^{238} \mathrm{PuCl}_{3}$ is about doubled and the amount of ${ }^{239} \mathrm{PuCl}_{3}$ is the same. It is curious that no oxide moves into the product fractions. The cause of this may come from the settling of the solid species in the liquid salt solution. Thus, the Fe metal and Pu oxide settle to the bottom of the crucible during the time the mechanical mixing device is raised from the mixture and allowed to drip adhered material back into the reaction vessel.

Table 3A. Component Masses (grams) of Fractions According to Process Chemistry Analysis Based on $\mathrm{PuO}_{2}$ Formation Model

\begin{tabular}{|l|l|l|l|l|l|l|l|l|l|}
\hline & Total & $\begin{array}{c}{ }^{238} \mathrm{Pu} \\
\text { Metal }\end{array}$ & ${ }^{238} \mathrm{PuO}_{2}$ & $\mathrm{FeCl}_{2}$ & $\begin{array}{c}\mathrm{LiCl} / \\
\mathrm{KCl}\end{array}$ & $\begin{array}{c}\mathrm{Fe} \\
\mathrm{Metal}\end{array}$ & ${ }^{23} \mathrm{PuCl}_{3}$ & $\begin{array}{c}{ }^{239} \mathrm{Pu} \\
\mathrm{Metal}\end{array}$ & ${ }^{239} \mathrm{PuCl}_{3}$ \\
\hline \hline $\begin{array}{l}\text { 1st } \\
\text { oxidation } \\
\text { input } \\
\text { masses }\end{array}$ & 6.109 & 0.727 & 1.232 & 1.558 & 2.592 & & & & \\
\hline $\begin{array}{l}\text { 1st } \\
\text { oxidation } \\
\text { product }\end{array}$ & 3.285 & & 0.001 & 0.695 & 1.842 & & 0.747 & & \\
\hline $\begin{array}{l}\text { 1st } \\
\text { oxidation } \\
\text { analysis } \\
\text { sample }\end{array}$ & 0.043 & 0.000 & 0.009 & 0.024 & & 0.010 & & \\
\hline $\begin{array}{l}\text { 1st } \\
\text { oxidation } \\
\text { magnetic } \\
\text { separation }\end{array}$ & 2.393 & & 1.152 & 0.212 & 0.562 & 0.239 & 0.228 & & \\
\hline
\end{tabular}


Table 3A. (Contd.)

\begin{tabular}{|l|l|l|l|l|l|l|l|l|l|}
\hline & Total & $\begin{array}{c}{ }^{238} \mathrm{Pu} \\
\text { Metal }\end{array}$ & ${ }^{238} \mathrm{PuO}_{2}$ & $\mathrm{FeCl}_{2}$ & $\begin{array}{c}\mathrm{LiCl} / \\
\mathrm{KCl}\end{array}$ & $\begin{array}{c}\mathrm{Fe} \\
\mathrm{Metal}\end{array}$ & ${ }^{238} \mathrm{PuCl}_{3}$ & $\begin{array}{c}{ }^{239} \mathrm{Pu} \\
\text { Metal }\end{array}$ & ${ }^{239} \mathrm{PuCl}_{3}$ \\
\hline \hline $\begin{array}{l}\text { 1st } \\
\text { oxidation } \\
\text { loss }\end{array}$ & 0.387 & & 0.078 & 0.062 & 0.164 & 0.016 & 0.067 & & \\
\hline $\begin{array}{l}\text { 2nd } \\
\text { oxidation } \\
\text { input } \\
\text { masses }\end{array}$ & 4.159 & & 0.001 & 0.695 & 1.842 & & 0.747 & 0.874 & \\
\hline $\begin{array}{l}\text { 2nd } \\
\text { oxidation } \\
\text { product }\end{array}$ & 2.859 & & 0.001 & & 1.367 & & 0.554 & & 0.937 \\
\hline $\begin{array}{l}\text { 2nd } \\
\text { oxidation } \\
\text { analysis } \\
\text { sample }\end{array}$ & 0.051 & 0.000 & & 0.024 & & 0.010 & & 0.017 \\
\hline $\begin{array}{l}\text { 2nd } \\
\text { oxidation } \\
\text { magnetic } \\
\text { separation }\end{array}$ & 0.780 & 0.000 & & 0.243 & 0.272 & 0.099 & & 0.167 \\
\hline $\begin{array}{l}\text { 2nd } \\
\text { oxidation } \\
\text { loss }\end{array}$ & 0.469 & & 0.000 & & 0.208 & 0.035 & 0.084 & & 0.142 \\
\hline
\end{tabular}

Table 4A lists the isotopic breakdown and mass fractions in the various process steps for the model described in Table 3A. Table 4A shows that the total Pu content of the ceramic waste form is about $3 \%$ of the mass. The ${ }^{238} \mathrm{Pu}:{ }^{239} \mathrm{Pu}$ ratio is about $1: 2$ (half that found in the $\mathrm{Pu}_{2} \mathrm{O}_{3}$ model) and that the ${ }^{238} \mathrm{Pu}$ makes up slightly less than $1 \%$ of the mass of the final ceramic waste form, again half that found in the $\mathrm{Pu}_{2} \mathrm{O}_{3}$ model. 
Table 4A. Weight Fractions of Pu Isotopes and Total Pu in Products of Process Steps to Form Ceramic Waste Form Based on $\mathrm{PuO}_{2}$ Formation Model

\begin{tabular}{|l|c|c|c|c|}
\hline & $\begin{array}{c}\text { Mass Final } \\
\text { Product } \\
\text { Oxidation } \\
\text { Process }\end{array}$ & $\begin{array}{c}\text { Relative Isotope } \\
\text { Fraction in Final } \\
\text { Oxidation } \\
\text { Process }\end{array}$ & $\begin{array}{c}\text { Weight } \\
\text { Fraction of } \\
\text { Pu in Zeolite } \\
\text { Contact } \\
\text { Process }\end{array}$ & $\begin{array}{c}\text { Weight Fraction } \\
\text { in Final Zeolite/ } \\
\text { Glass/Salt } \\
\text { Mixture }\end{array}$ \\
\hline${ }^{238} \mathrm{Pu}$ & 0.33962 & 0.32888 & 0.01311 & 0.00983 \\
\hline${ }^{239} \mathrm{Pu}$ & 0.61180 & 0.59246 & 0.02362 & 0.01772 \\
\hline${ }^{240} \mathrm{Pu}$ & 0.07608 & 0.07368 & 0.00294 & 0.00220 \\
\hline${ }^{241} \mathrm{Pu}$ & 0.00358 & 0.00346 & 0.00014 & 0.00010 \\
\hline${ }^{242} \mathrm{Pu}$ & 0.00156 & 0.00151 & 0.00006 & 0.00005 \\
\hline Total $\mathrm{Pu}$ & 1.03264 & 1.00000 & 0.03986 & 0.02990 \\
\hline
\end{tabular}

Because the $\mathrm{PuO}_{2}$ model described in Table 3A suggested that settling might occur, a model was attempted to force the oxide into the magnetic separation fraction of the $\mathrm{Pu}_{2} \mathrm{O}_{3}$ model. It was not possible to accomplish this in the $1^{\text {st }}$ oxidation step as the result yielded total fractional masses significantly different from the measured masses. It was possible to accomplish this for the $2^{\text {nd }}$ oxidation step; however, this action resulted in no salt or dissolved species being carried into the magnetic separation fraction, which was not what was observed (although even qualitative experimental determination of the amounts of the various oxide and salt components was not possible). The results from this model are described in Table 5A and indicate a significantly reduced amount of oxide in the final product compared to the $\mathrm{Pu}_{2} \mathrm{O}_{3}$ model in Table 1A. It is not clear why no settling of the solids would occur in the $1^{\text {st }}$ oxidation but would happen to a partial extent in the $2^{\text {nd }}$ oxidation.

Table 5A. Component Masses (grams) of Fractions According to Process Chemistry Analysis Based on $\mathrm{Pu}_{2} \mathrm{O}_{3}$ Formation Model with Maximum Oxide Content in Magnetic Separation Phase of $2^{\text {nd }}$ Oxidation

\begin{tabular}{|l|c|c|c|c|c|c|c|c|c|}
\hline & Total & $\begin{array}{c}{ }^{238} \mathrm{Pu} \\
\mathrm{Metal}\end{array}$ & ${ }^{238} \mathrm{Pu}_{2} \mathrm{O}_{3}$ & $\mathrm{FeCl}_{2}$ & $\begin{array}{c}\mathrm{LiCl} / \\
\mathrm{KCl}\end{array}$ & $\begin{array}{c}\mathrm{Fe} \\
\mathrm{Metal}\end{array}$ & ${ }^{238} \mathrm{PuCl}_{3}$ & $\begin{array}{c}{ }^{239} \mathrm{Pu} \\
\text { Metal }\end{array}$ & ${ }^{239} \mathrm{PuCl}_{3}$ \\
\hline \hline $\begin{array}{l}\text { 1st } \\
\text { oxidation } \\
\text { input } \\
\text { masses }\end{array}$ & 6.109 & 0.367 & 1.592 & 1.558 & 2.592 & & & & \\
\hline
\end{tabular}


Table 5A. (Contd.)

\begin{tabular}{|l|l|l|l|l|l|l|l|l|l|}
\hline & Total & $\begin{array}{c}{ }^{238} \mathrm{Pu} \\
\mathrm{Metal}\end{array}$ & ${ }^{238} \mathrm{Pu}_{2} \mathrm{O}_{3}$ & $\mathrm{FeCl}_{2}$ & $\begin{array}{c}\mathrm{LiCl} / \\
\mathrm{KCl}\end{array}$ & $\begin{array}{c}\mathrm{Fe} \\
\mathrm{Metal}\end{array}$ & ${ }^{238} \mathrm{PuCl}_{3}$ & $\begin{array}{c}{ }^{239} \mathrm{Pu} \\
\mathrm{Metal}\end{array}$ & ${ }^{239} \mathrm{PuCl}_{3}$ \\
\hline $\begin{array}{l}\text { 1st } \\
\text { oxidation } \\
\text { product }\end{array}$ & 3.285 & & 0.875 & 0.695 & 1.424 & & 0.292 & & \\
\hline $\begin{array}{l}\text { 1st } \\
\text { oxidation } \\
\text { analysis } \\
\text { sample }\end{array}$ & 0.043 & & 0.011 & 0.009 & 0.019 & & 0.004 & & \\
\hline $\begin{array}{l}\text { 1st } \\
\text { oxidation } \\
\text { magnetic } \\
\text { separation }\end{array}$ & 2.393 & & 0.605 & 0.481 & 0.985 & 0.121 & 0.202 & & \\
\hline $\begin{array}{l}\text { 1st } \\
\text { oxidation } \\
\text { loss }\end{array}$ & 0.387 & 0.101 & 0.080 & 0.164 & 0.008 & 0.034 & & \\
\hline $\begin{array}{l}\text { 2nd } \\
\text { oxidation } \\
\text { input } \\
\text { masses }\end{array}$ & 4.159 & & 0.875 & 0.695 & 1.424 & & 0.292 & 0.874 & \\
\hline $\begin{array}{l}\text { 2nd } \\
\text { oxidation } \\
\text { product }\end{array}$ & 2.859 & & 0.263 & & 1.241 & & 0.254 & & 1.101 \\
\hline $\begin{array}{l}\text { 2nd } \\
\text { oxidation } \\
\text { analysis } \\
\text { sample }\end{array}$ & 0.051 & 0.005 & & 0.022 & & 0.005 & & 0.020 \\
\hline $\begin{array}{l}\text { 2nd } \\
\text { oxidation } \\
\text { magnetic } \\
\text { separation }\end{array}$ & 0.780 & & 0.508 & & 0.000 & 0.272 & 0.000 & & 0.000 \\
\hline $\begin{array}{l}\text { 2nd } \\
\text { oxidation } \\
\text { loss }\end{array}$ & 0.469 & & 0.099 & & 0.161 & 0.035 & 0.033 & & 0.142 \\
\hline
\end{tabular}

Table 6A lists the isotopic breakdown and mass fractions in the various process steps for the model described in Table 5A. Table 6A shows that the total Pu content of the ceramic waste form is about $3.4 \%$ of the mass, less than the $\mathrm{Pu}_{2} \mathrm{O}_{3}$ model and slightly more than the $\mathrm{PuO}_{2}$ model. The ${ }^{238} \mathrm{Pu}$ : ${ }^{239} \mathrm{Pu}$ ratio is about 1:2 (half that found in the $\mathrm{Pu}_{2} \mathrm{O}_{3}$ model and similar to the $\mathrm{PuO}_{2}$ 
model and that the ${ }^{238} \mathrm{Pu}$ makes up slightly more than $1 \%$ of the mass of the final ceramic waste form, again half that found in the $\mathrm{Pu}_{2} \mathrm{O}_{3}$ model and close to the $\mathrm{PuO}_{2}$ model.

Table 6A. Weight Fractions of Pu Isotopes and Total Pu in Products of Process Steps to Form Ceramic Waste Form Based on $\mathrm{Pu}_{2} \mathrm{O}_{3}$ Formation Model with

Maximum Oxide Content in Magnetic Separation Phase of $2^{\text {nd }}$ Oxidation

\begin{tabular}{|l|c|c|c|c|}
\hline & $\begin{array}{c}\text { Mass Final } \\
\text { Product Oxidation } \\
\text { Process }\end{array}$ & $\begin{array}{c}\text { Relative Isotope } \\
\text { Fraction in Final } \\
\text { Oxidation Process }\end{array}$ & $\begin{array}{c}\text { Weight Fraction } \\
\text { of Pu in Zeolite } \\
\text { Contact Process }\end{array}$ & $\begin{array}{c}\text { Weight Fraction in } \\
\text { Final Zeolite/ } \\
\text { Glass/Salt Mixture }\end{array}$ \\
\hline \hline${ }^{238} \mathrm{Pu}$ & 0.36675 & 0.31171 & 0.01416 & 0.01062 \\
\hline${ }^{239} \mathrm{Pu}$ & 0.71467 & 0.60741 & 0.02759 & 0.02070 \\
\hline${ }^{240} \mathrm{Pu}$ & 0.08914 & 0.07576 & 0.00344 & 0.00258 \\
\hline${ }^{241} \mathrm{Pu}$ & 0.00420 & 0.00357 & 0.00016 & 0.00012 \\
\hline${ }^{242} \mathrm{Pu}$ & 0.00183 & 0.00155 & 0.00007 & 0.00005 \\
\hline Total $\mathrm{Pu}$ & 1.17658 & 1.00000 & 0.04542 & 0.03407 \\
\hline
\end{tabular}

Compared to the chemical elemental and isotopic analysis performed the best models are the $\mathrm{PuO}_{2}$ model and the $\mathrm{Pu}_{2} \mathrm{O}_{3}$ model in which a maximum amount of oxide was forced into the magnetic separation fraction of the $2^{\text {nd }}$ oxidation step. The $\mathrm{PuO}_{2}$ model had a natural fallout where virtually no oxide was transferred to the product fraction of the $1^{\text {st }}$ oxidation. In both cases the ${ }^{238} \mathrm{Pu}:{ }^{239} \mathrm{Pu}$ ratios are about $1: 2$ and the ${ }^{238} \mathrm{Pu}$ is about $1 \%$ of the final ceramic waste form mass. These are about half the values determined from the chemical elemental and isotopic analysis. One possible explanation for this is that under the conditions of the reactions, the $\mathrm{Fe}_{2} \mathrm{Pu}$ inter-metallic formed despite the fact that its formation energy is very unfavorable compared to formation of $\mathrm{PuCl}_{3}$. This solid would thus likewise settle out and be preferentially carried into the magnetic separation fraction thereby reducing the ${ }^{238} \mathrm{Pu}$ metal available for oxidation to $\mathrm{PuCl}_{3}$. This model is most appropriate to the $\mathrm{PuO}_{2}$ model. This model has not yet been quantified. 